\title{
Policing Terrorists in the Community
}

Sahar F. Aziz

Texas A\&M University School of Law, saziz@law.tamu.edu

Follow this and additional works at: https://scholarship.law.tamu.edu/facscholar

Part of the Law Commons

\section{Recommended Citation}

Sahar F. Aziz, Policing Terrorists in the Community, 5 Harv. Nat'I Sec. J. 147 (2014).

Available at: https://scholarship.law.tamu.edu/facscholar/96

This Article is brought to you for free and open access by Texas A\&M Law Scholarship. It has been accepted for inclusion in Faculty Scholarship by an authorized administrator of Texas A\&M Law Scholarship. For more information, please contact aretteen@law.tamu.edu. 


\title{
ARTICLE \\ Policing Terrorists in the Community
}

\author{
Sahar F. Aziz
}

\begin{abstract}
Twelve years after the September 11th attacks, countering domestic terrorism remains a top priority for federal law enforcement agencies. Using a variety of reactive and preventive tactics, law enforcement seeks to stop terrorism before it occurs. Towards that end, community policing, developed in the 1990s to combat violent crime in inner city communities, is being adopted as a means of collaborating with Muslim communities and local police to combat "Islamist homegrown terrorism." Developed in response to paramilitary policing models, community policing is built upon the notion that effective policing requires mutual trust and relationships among local law enforcement and the communities they serve.
\end{abstract}

While community policing in counterterrorism appears facially sound, this Article proffers that this endeavor is fraught with peril, both for collective civil liberties and the interests of local police in preserving relationships of trust. Accordingly, this Article examines how community policing exacerbates, rather than resolves, the underlying post-9/11 subordination of Muslims arising from preventive counterterrorism policies, notwithstanding the increase of homegrown terrorism threats from non-Muslim groups. The Article asserts three critiques of community policing in counterterrorism: (1) it is more akin to counter-radicalization taken from military

\footnotetext{
* Associate Professor, Texas A\&M University School of Law. J.D., University of Texas School of Law; M.A., Middle East Studies, University of Texas. Professor Aziz previously served as a Senior Policy Advisor at the U.S. Department of Homeland Security Office for Civil Rights and Civil Liberties. Professor Aziz thanks the Texas A\&M University School of Law for the generous research support, Professors Mary Penrose, Huyen Pham, Frank Snyder, and Timothy Mulvaney for their mentorship, and the Texas A\&M University Law Librarians for their exceptional research support. Professor Aziz also thanks Professors Aziz Huq, Richard Delgado, Angela Harris, Steven Wizner, Ali Khan, David Super, Ben Davis, and William Banks for their thoughtful insights and feedback of earlier drafts of this Article. Thanks to the able research assistance of Casey Brown, Chuck Hill, Natalia Cashen, and Larisa Maxwell. And a special thanks to Rusty Roeger and Danielle Jefferis for going the extra mile on this project. All errors are mine alone.
} 
counterinsurgency strategy than the partnership-based, traditional community policing model; (2) to the collective detriment of Muslim communities, it divides them into "Good Muslims" willing to cooperate with law enforcement on the federal government's terms and "Bad Muslims" who demand a meaningful quid quo pro that ensures protection of Muslim communities' civil rights and liberties; and (3) it deputizes Muslim leaders to gather and share seemingly innocuous information about their communities that may be used against their collective interests as part of the predominantly federal prosecution-driven counterterrorism regime.

Unless systemic reforms are made to federal preventive counterterrorism strategies, community policing is likely to aggravate existing civil liberties violations and impair otherwise good relations between Muslim communities and local police. Thus, a serious rethinking of proposals to implement community policing in counterterrorism is warranted.

\section{Introduction}

Over the past few years, federal government officials have expressed concerns over an increasing "Islamist homegrown terrorist" threat $^{2}$ High-profile cases involving "lone wolves" accused of terrorist plots on U.S. soil, coupled with public perceptions of Muslims as prone to terrorism, have triggered a flurry of Congressional hearings and executive reports recommending harsher counterterrorism enforcement focused on Muslim communities. Meanwhile, critics of "hard" counterterrorism tactics propose increasing community outreach to Muslim communities, through community policing in particular, as the solution to homegrown terrorism. ${ }^{3}$ As a consequence, community policing has become popular both among policy makers seeking to be more preventive in counterterrorism and

\footnotetext{
1 See Headquarters, U.S. Dep't of the Army, Counterinsurgency 1-19-29 (2006), available at http://www.fas.org/irp/doddir/army/fm3-24.pdf (describing counterinsurgency efforts to integrate culturally sensitive activities designed to ensure the security and welfare of the nation's populace to win their favor with typical military activities to defeat the enemy).

2 See Matthew C. Waxman, Police National Security: American Local Law Enforcement and Counterterrorism After 9/11, 3 J. NAT'L SEC. L. \& POL'Y 377, 382-83 (2009).

3 See, e.g., Mohamed Elibiary, Boston Bombings and the Radicalized Homegrown Terrorist, WASH. POST, Apr. 30, 2013, http://www.washingtonpost.com/blogs/on-faith/wp/ 2013/04/30/boston-bombings-and-the-radicalized-homegrown-terrorist/, [http:// perma.law.harvard.edu/0pyHBG3p4nG].
} 
Muslim community leaders concerned with protecting the civil liberties of their constituents. ${ }^{4}$

By challenging the underlying presumptions of those calling for community policing in counterterrorism, this Article argues that adversarial, federal counterterrorism enforcement cannot be reconciled with the partnership-based local community policing model. ${ }^{5}$ Community policing in counterterrorism as currently envisioned betrays its rhetoric of empowerment and mutual trust, and serves as another weapon in the federal government's toolkit that perpetuates the "Terrorist Other" stereotype. ${ }^{6}$ Until this stereotype can be stripped away from "hard on terror" preventive counterterrorism strategies, the benefits gained in the traditional local community policing model of the 1990 s are unlikely to be realized. ${ }^{7}$

4 See, e.g., Homeland SEC. Advisory COUncil, COUNTERING Violent Extremism (CVE) WORKING GROUP 5 (2010), http://www.dhs.gov/xlibrary/assets/ hsac_cve_working_group_recommendations.pdf, [http://perma.cc/06SULsqs3j6]; EXEC. OFFICE OF THE PRESIDENT OF THE U.S., STRATEGIC IMPLEMENTATION Plan FOR EMPOWERING Local Partners to PrEVEnt Violent EXTREMISM IN THE UNITED States 16 (Dec. 2011), available at http://www.whitehouse.gov/sites/default/files/sip-final.pdf, [http://perma.cc/0ZGrrHAbzDt/] [hereinafter STRATEGIC PLAN FOR EMPOWERING LOCAL PARTNERS]; Eileen Sullivan, Community Outreach Key to Obama Counterterror Plan, ASSOCIATED PRESS, May 25, 2013, http://bigstory.ap.org/article/community-outreach-keyobama-counterterror-plan, [http://perma.law.harvard.edu/0xivLXCA9Cx/]; Michael Hirsch, Stopping Terrorism at the Source, NAT'L J., May 2, 2013, http://www.nationaljournal.com/ magazine/stopping-terrorism-at-the-source-20130502?print=true, [http:// perma.law.harvard.edu/0kdXA3qXdTW] (discussing that some Muslim community leaders are willing to work with the Obama Administration's strategy but are growing impatient with delays likely due to funding issues and the lack of organization and leadership).

5 See, e.g., Derrick Bell, Brown v. Board of Education and the Interest-Convergence Dilemma, 93 HARV. L. REV. 518, 523 (1980) (defining interest convergence theory); David A. Harris, Law Enforcement and Intelligence Gathering in Muslim and Immigrant Communities After 9/11, 34 N.Y.U. REV. L. \& SoC. CHANGE 123, 162 (2010); Sudha Setty, National Security Interest Convergence, 4 HARV. NAT'L SEC. J. 185 (2012); MICHAEL Price, National Security and Local Police, Brennan Ctr. For Just. 1 (Dec. 2013), available at http://www.brennancenter.org/publication/national-security-local-police, [http://perma.cc/5CMN-MK7L].

6 See, e.g., Leti Volpp, The Citizen and the Terrorist, 49 U.C.L.A. L. REV. 1575 (2002); Joseph Margulies \& Hope Metcalf, Terrorizing Academia, 60 J. LEGAL EdUC. 433, 436 (2011); Margaret Chon \& Donna E. Arzt, Walking While Muslim, 68 LAW \& CONTEMP. ProBs. 215, 229 (2005); Madalla A. Alibeli \& Abdulfattah Yaghi, Theories of Prejudice and Attitudes Toward Muslims in the United States, 2 INT'L J. OF HuMANITIES \& SOC. SCI. 1 (2012) (discussing the scapegoating of American Muslims).

7 John Murray, Policing Terrorism: A Threat to Community Policing or Just a Shift in Priorities?, 6 POLICE PRAC. \& Res. 347, 348 (2005). 
Put simply, community policing co-opts Muslim community leaders into gathering and sharing intelligence on Muslims' political beliefs, religious practices, and other information otherwise unavailable to law enforcement due to constitutional constraints. ${ }^{8}$ Believing they are serving the best interests of Muslim communities, ${ }^{9}$ many unwitting participants disclose the goings-on of the community and provide information about the politics of community leaders and mosques. This enables law enforcement's investigative arm to reach deeper into Muslim communities' affairs than they could otherwise, resulting in a de facto deputizing effect. ${ }^{10}$ All the while, aggressive counterterrorism enforcement practices and policies focused exclusively on Muslims remain unchanged. ${ }^{11}$

In contrast to traditional community policing where citizens seek the protection of local law enforcement from third-party drug dealers, gangsters, and other criminal elements, Muslim communities engage with federal law enforcement to dissuade them from spying on their mosques and social gatherings, ${ }^{12}$ targeting their vulnerable youth in informant-led terrorist plots, ${ }^{13}$ prosecuting their charities for giving humanitarian aid to

8 See, e.g., Harris, supra note 5, at 161; Will McCants \& Clint Watts, U.S. Strategy for Countering Violent Extremism: An Assessment, ForeIGN POL'Y RES. INST. 5 (Dec. 2012), available at https://www.fpri.org/docs/McCants_Watts_-_Countering_Violent_ Extremism.pdf, [www.perma.cc/0dH6R $7 \mathrm{mqXaU}$ ] (highlighting contradiction in White House's Countering Violent Extremism Strategy that aims to avoid securitization of Muslims but which, by focusing exclusively on Muslims, still sends the message "You Muslims are a potential threat and we, the government, have to co-opt you"); Waxman, supra note 2 , at $401-02$.

9 See Ryan Hunter \& Danielle Heinke, Radicalization of Islamist Terrorists in the Western World, FBI LAW ENFORCEMENT Bull. 27-29 (Sept. 2011), http://www.fbi.gov/statsservices/publications/law-enforcement-bulletin/september-2011/perspective, [http:// perma.law.harvard.edu/0WBpj4S4xsv/] (finding voluntary cooperation by Muslim Americans in anti-terror policing more likely when authorities are viewed as more legitimate).

${ }^{10}$ See Harris, supra note 5, at 127.

11 See American Civil Liberties Union, Establishing a New Normal: National SeCurity, Civil Liberties, and Human Rights Under the Obama Administration (2010), available at http://www.aclu.org/files/assets/EstablishingNewNormal.pdf.

${ }^{12}$ See Harris, supra note 5, passim for a discussion of the harm to community relations that the use of informants can cause, and the suggested use of a negotiated agreement between community members and the FBI regarding its use of informants in the community.

13 See Alexandra Natapoff, Snitching: Institutional and Communal Consequences, 73 U. CIN. L. REV. 645, 645-46 (2004), for a discussion of the community harms that informant use can create. See generally CTR. ON LAW \& SeC., N.Y.U. SCH. Of L., TEN YEARS LaTER: Terrorist Trial Report CARD: SePtember 11, 2001-SePtember 11, 201126 (2011) 
conflict zones, ${ }^{14}$ and adopting invidious counterterrorism tactics that destroy community bonds. ${ }^{15}$ And as they beseech their government to respect their civil liberties, Muslims must also seek the protection of law enforcement against private acts of violence and discrimination. ${ }^{16}$ For many Muslims, the government may come across as more a foe than a friend. ${ }^{17}$

Thus, counterterrorism community policing ("CCP") is not, nor is it intended to be, the same as community policing in the traditional criminal context. ${ }^{18}$ Rather than fundamentally changing relations between law enforcement and communities into a partnership, CCP perpetuates preventive counterterrorism strategies that prioritize the surveillance, investigation, prosecution, and conviction of Muslims. ${ }^{19}$

available at http://www.lawandsecurity.org/Portals/0/Documents/TTRC\%20Ten\%20Year \%20Issue.pdf.

14 See David Cole, Terror Financing, Guilt by Association and the Paradigm of Prevention in the 'War on Terror,' in COUNTERTERrorism: Democracy's Challenge 233 (Bianchi \& Keller eds., 2008).

${ }^{15}$ See Murad Hussain, Defending the Faithful: Speaking the Language of Group Harm in Free Exercise Challenges to Counterterrorism Profiling, 117 YALE L.J. 920,939 (2008);

see Sameer M. Ashar, Immigration Enforcement and Subordination: The Consequences of Racial Profiling After September 11, 34 CONN. L. REV. 1185, 1196 (2002).

16 See Ashar, supra note 15, at 1196; see also Marc Santora, Woman is Charged with Murder as a Hate Crime in a Fatal Subway Push, N.Y. TIMES, Dec. 29, 2012, http:// www.nytimes.com/2012/12/30/ny region/woman-is-held-in-death-of-man-pushed-ontosubway-tracks-in-queens.html?_r=0, [http://perma.law.harvard.edu/0tz7gs5Zyo9/] (describing woman who pushed man on tracks, where he was fatally crushed by an oncoming train, because he "looked Muslim or Hindu" and the woman "hate[d] Muslim and Hindus ever since 2001").

17 See Exec. Office of the President of the U.S., Empowering Local Partners to PREVENT VIOLENT EXTREMISM IN THE UNITED STATES 7 (Aug. 2011), available at http:// www.whitehouse.gov/sites/default/files/empowering_local_partners.pdf, [www.perma.cc/ 06PpqkunXzn] [hereinafter EMPOWERING Local ParTNERs]; Strategic Plan FOR EMPOWERING LoCAl PARTNERs, supra note 4, at 20; BIPARTISAN POL'y CTR., PREVENTING VIOLENT RADICALIZATION IN AMERICA 28 (June 2011), available at http:// bipartisanpolicy.org/sites/default/files/NSPG.pdf; Vera Chinese \& Simone Weichselbaum, Man Stabbed Outside Queens Mosque, Attacker Screamed Anti-Muslim Rant, Say Cops, N.Y. DAILY NEWS, Nov. 18, 2012, http://www.nydailynews.com/news/crime/man-stabbedqueens-mosque-article-1.1204122, [http://perma.law.harvard.edu/05GBluwT64X]; Nigel Duara, Ore. Muslim Sues FBI, Claims Torture, Associated Press, May 30, 2013, http:// bigstory.ap.org/article/apnew sbreak-ore-muslim-sues-fbi-claims-torture, [http:// perma.law.harvard.edu/0HbGqRBK $5 \mathrm{vD} /]$ (describing one man's beatings and interrogations while held captive overseas, allegedly at the command of the FBI).

${ }^{18}$ See, e.g., Harris, supra note 5 at 133-34.

19 See, e.g., Ten Years after 9/11-Are We Safer?: Hearing before the S. Comm. on Homeland Sec. \& Governmental Aff., 112th Cong. (2011), available at http://www.fbi.gov/ news/testimony/ten-years-after-9-11-are-we-safer, [http://perma.law.harvard.edu/ 
As a result, Muslims have little choice but to engage with the same entities that both violate their civil liberties and legitimize civil rights violations by private actors. ${ }^{20}$ Indeed, for many Muslim proponents of the practice, community policing offers a formal mechanism to reform counterterrorism practices that adversely impact Muslim communities. This Article examines how community policing exacerbates, rather than resolves, the underlying subordination of Muslims manifested in racialized counterterrorism policies, ${ }^{21}$ notwithstanding the increase of homegrown terrorism threats from non-Muslim groups. ${ }^{22}$

Proponents of community policing between law enforcement and Muslim communities erroneously presume a convergence of interests between the two. Moreover, they shortsightedly focus on local policing when in practice, federal law enforcement agencies drive counterterrorism enforcement. ${ }^{23}$ I challenge the underlying assumption that the interests of law enforcement and Muslim communities converge. Indeed, community

03TwhZGoQoz/] [hereinafter Ten Years After 9/11 Hearings] (statement of Robert S. Mueller, III, Director, FBI) ("To meet the growing demand for surveillance, the Bureau has increased the number of unarmed surveillance teams by 127 percent since 2001."); MARC Lynch, Rhetoric and Reality: Countering Terrorism in the AGe of Obama 14 (June 2010), available at http://www.cnas.org/files/documents/publications/ CNAS_Rhetoric\%20and\%20Reality_Lynch.pdf; JudE MCCullOCH, BLUE ARMY: PARAMILITARY POlicing IN Victoria 31 (2001); Price, supra note 5, at 7 (noting the post-9/11 change towards "intelligence-led policing").

20 See Empowering Local Partners, supra note 17 , and Strategic Plan for EMPOWERING LOCAL PARTNERS, supra note 4, which detail the Obama Administration's community engagement plan. See also Hussain, supra note 15, at 934; Ashar, supra note 15 , at 1196 .

21 See Hilal Elver, Racializing Islam Before and After 9/11: From Melting Pot to Islamophobia, 21 TRANSNAT'L L. \& CONTEMP. ProBS. 119, 139-45 (2012) (discussing racial element of immigration laws and Patriot Act); DAVID COLE \& JULES LoBEL, Less SAFE, LESS FREE 102-28 (2007) (providing additional examples of policies proven ineffective in promoting national security while also reinforcing racial bias).

22 See CTR. ON LAW \& SEC., supra note 13, at 7 (reporting that of the 1,054 total terrorrelated cases prosecuted since 9/11, 578 involved Muslims and 476 did not involve Muslims or Islam); SoutHERn POVERTY LAW CTR., Terror from the Right: Plots, Conspiracies and Racist Rampages Since Oklahoma City (2012), available at http:// www.splcenter.org/sites/default/files/downloads/publication/terror_from_the _right_2012_web_0.pdf (detailing the nearly 100 plots, conspiracies, and racist acts of radical right groups and individuals since 1995 ).

23 See Prevent Terrorism and Enhance Security, U.S. DeP'T OF HOMELand SEC., http:// www.dhs.gov/prevent-terrorism-and-enhance-security, [http://perma.law.harvard.edu/ 0VKpnydYTtU/] (describing the Department of Homeland Security's primary goal to prevent terrorist acts); Joint Terrorism Task Force, U.S. DEP'T OF JUST., http:// www.justice.gov/jttf/, [http://perma.law.harvard.edu/0mjActZyfW7/] (noting that the 
policing is merely an extension of the federal government's prosecutorial approach that prioritizes law enforcement's interests in expanding the number of anti-terrorism investigations and prosecutions ${ }^{24}$ at the expense of key collective rights of American Muslim communities and community alliances that are essential to defeat genuine terrorism threats. These collective liberties include the rights to be free from surveillance, to practice their religion without undue scrutiny by the state, to travel to their countries of origin without fear of being placed on watch lists or No-Fly Lists, and to mobilize their communities politically without being subjected to closer government scrutiny. ${ }^{25}$

Rather than meaningfully addressing these problems, community policing bolsters the broader strategy of integrating local police as the eyes and ears on the ground in the federal counterterrorism regime. ${ }^{26}$ As a result, attractive federal grants seduce some local law enforcement into the process, ${ }^{27}$ while others eventually cease the project to preserve the credibility necessary to receive community assistance in order to fight local,

Department of Justice and FBI lead the Joint Terrorism Task Forces through which both state and federal law enforcement specialists join forces to combat terrorism).

24 See, e.g., Ten Years After 9/11 Hearings, supra note 19 ("The FBI's actions are not limited to arrests and prosecutions; they take many forms-including recruiting potential intelligence sources . . . ."); see generally Paul Butler, Gideon's Muted Trumpet, N.Y. TIMES, Mar. 17, 2013, http://www.nytimes.com/2013/03/18/opinion/gideons-mutedtrumpet.html?ref=opinion\&_r $=0$, [http://perma.law.harvard.edu/0PRQcCceM3P/] (noting that "[t]he Supreme Court has famously stated that the prosecutor's interest 'is not that it shall win a case, but that justice shall be done.' In our adversarial system, however, those are just words on paper").

25 See, e.g., Jerome P. Bjelopera, Cong. Research Serv., R42553, Countering VIOLENT EXTREMISM IN THE UNITED STATES 14, 17 (May 31, 2012), available at http:// www.fas.org/sgp/crs/homesec/R42553.pdf (noting the need for training so officers can distinguish when constitutionally protected activity crosses the line to criminal activity); Gadeir Abbass \& Adam Soltani, CAIR Officials: Man Sentenced to Life Without Air Travel, NEwSOK, Feb. 13, 2013, http://newsok.com/cair-officials-man-sentenced-to-life-withoutair-travel/article/3754641/?page=1, [http://perma.law.harvard.edu/0uF1o47efem/].

26 See Working with Communities to Disrupt Terror Plots: Hearing Before the Subcomm. on Intelligence, Info. Sharing, and Terrorism Risk Assessment of the H. Comm. of Homeland Sec., 111th Cong. 1 (2010), available at http://www.gpo.gov/fdsys/pkg/ CHRG-111hhrg57457/html/CHRG-111hhrg57457.htm, [http://perma.law.harvard.edu/ 0kNWrywb1Fv/] [hereinafter Working with Communities Hearing] (statement of Jane Harman, Chair).

27 See The American Muslim Response to Hearings on Radicalization within their Community: Hearing Before H. Comm. on Homeland Sec., 112th Cong. (2012), available at http://www.dhs.gov/news/2012/06/22/statement-record-principal-deputycounterterrorism-coordinator-john-cohen-house, [http://perma.law.harvard.edu/ 0GpuLtvt7Ke/] (statement of John Cohen, Principal Deputy Counterterrorism Coordinator) 
non-terrorism crimes. ${ }^{28}$ In the end, for community policing to work, federal law enforcement culture and practices must abandon the prosecutorial, collective approach to policing and focus suspicion on individuals based on predicate acts of criminal activity. In light of post-9/11 politics, which are built on the assumption that Muslims are inherently prone to terrorism, ${ }^{29}$ such changes are unlikely in the near future.

After describing the preventive counterterrorism strategy that underpins CCP, Part II examines and critiques community outreach and engagement programs that precede current calls for CCP. I call into question the federal government's motives behind CCP based on its record of civil liberties violations arising from community outreach and engagement programs promoted, in part, to counter-radicalize and gather intelligence on Muslim communities. Part III argues that community policing is an extension of a counterterrorism strategy that collectively subordinates Muslim communities. Rather than empower communities to reform rightsinfringing government practices, community policing co-opts them into not only accepting but also legitimizing such practices. ${ }^{30}$ Part IV concludes with recommendations to de-racialize domestic counterterrorism; remove the counterterrorism objectives from community policing with Muslim

(noting that DHS has expanded FY2012 grant guidance to include funding for CVE training, partnerships with local communities, and local CVE engagements in furtherance of White House's strategy); Waxman, supra note 2, at 399-400; John Sharp, Mobile Police Department Seeking \$1.7 Million Grant to Add 15 New Police Officers, AL.COM (May 15, 2013), http://blog.al.com/live/2013/05/mobile_police_department_seeki.html, [http:// perma.law.harvard.edu/0M6uXoMErAP/].

${ }^{28}$ See, e.g., HOMELAND SEC. ADVISORY COUNCIL, supra note 4, at 17 (recognizing "tension between federal law enforcement investigations and local partnerships to stop violent crime"); Sam Adams, Portland Offers Model on Terrorism Investigations, SFGATE, Apr. 3 , 2012, http://www.sfgate.com/opinion/openforum/article/Portland-offers-model-onterrorism-investigations-3454219.php, [http://perma.law.harvard.edu/0xvEHEphrjv/]; David A. Harris, The War on Terror, Local Police, and Immigration Enforcement: A Curious Tale of Police Power in Post-9/11 America, 38 RUTGERS L.J. 1, 43 (2006) (noting police refusal to participate in immigration enforcement as it impedes their ability to combat crime). But see April Baer, Portland Back In Joint Terrorism Task Force with Some Reservations, OPB (July 17, 2012), http://www.opb.org/news/article/portland-back-jointterrorism-task-force-some-reservations/, [http://perma.law.harvard.edu/0A33qrkfkLi/].

${ }^{29}$ See Cole, supra note 14 , at 234.

30 See, e.g., Harris, supra note 5, at 137; Alejandro J. Beutel, Building Bridges to Strengthen America: Forging an Effective Counterterrorism Enterprise between Muslim Americans and Law Enforcement, MUSLIM PUB. AFFS. COUNCIL (Nov. 2009), available at http://buildingbridgeswny.org/articles/MPAC-Counter-Radicalization-Paper.pdf (calling for increased funding for community policing as a means of "promot[ing] better intelligence 
communities; and ultimately de-securitize the relationship between Muslims and government such that they are treated like any other American community, more concerned with jobs, schools, and health care than terrorism. ${ }^{31}$

As long as countering terrorism is driven more by the identity of the suspect than by the nature of the crime, communities and local law enforcement alike should reject community policing in counterterrorism. ${ }^{32}$

\section{Community Policing in Counterterrorism}

Incorporating community policing into counterterrorism is not a new innovation. Community policing was introduced in the $1960 \mathrm{~s}$ as an alternative to the traditional paramilitary policing model that soured relations between law enforcement and minority communities. Community policing operates on the premise that in a democratic society, police need the assistance and resources of residents to address crime effectively. ${ }^{33}$ In theory, community policing is intended to empower minority communities to define policing priorities and, accordingly, to better serve the safety and

gathering and minimize[ing] the negative impact on both community-police relations"). In a future paper, I will engage in a programmatic critique based on a recognition that the political economy of community policing created by federal grants and a cottage industry of experts, coupled with the politics of terrorism in the U.S., nearly guarantees community policing's near-term survival despite the detrimental subordinating effects.

31 See Jihad Turk \& Salam Al-Marayati, U.S. Muslims are Not Measured by the Exemplary Work of its Mainstream, WASH. POST, Sept. 19, 2012, http://www.washingtonpost.com/ blogs/guest-voices/post/us-muslims-are-not-measured-by-the-exemplary-work-of-itsmainstream/2012/09/19/ef651132-0277-11e2-8102-ebee9c66e190_blog.html, [http:// perma.cc/JF3F-Q8Y2]; Exec. Order No. 13515, 74 Fed. Reg. 53,635 (Oct. 14, 2009) (regarding the need for increased Asian-American and Pacific Islander federal program participation in light of their continued disadvantages and challenges).

${ }^{32}$ Although others agree with my argument that community policing, also called countering violent extremism, should be abandoned, they focus on cost-benefit analysis as opposed to the subordinating and racialization basis of this Article. See, e.g., McCants \& Watts, supra note 8, at 5-6 (suggesting that if the numbers of terrorist group supporters and recruiters are small enough, that the government should abandon its countering violent extremism involvement and just apply traditional law enforcement methods to the problem); David Stevens, In Extremis: A Self-Defeating Element in the 'Preventing Violent Extremism' Strategy, 80 POL. Q. 517, 522-23 (2009) (arguing against government intervention in Muslim communities' affairs because an unfettered religious environment creates more moderation among religious institutions).

33 See Wesley G. Skogan, Community Policing: Can it Work? xx (2004); David A. Harris, Good Cops: The CASE for Preventive Policing (2005) (discussing the widespread use of community policing). 
socio-economic needs of their members. The model teaches communities to engage in self-help by acting in ways that the local government is unable or unwilling to do alone. ${ }^{34}$ As one scholar succinctly describes, "[community policing] is a philosophy of full-service personalized policing where the same officer patrols and works in the same area on a permanent basis, from a decentralized place, working in a proactive partnership with its citizens to identify and solve problems." 35 Community policing also facilitates twoway communication between the police and the public, encourages police to work with social services agencies to prevent crime before it occurs, and creates new channels for the police to learn more about neighborhood problems. ${ }^{36}$ Nonetheless, community policing remains a work in progress and has produced mixed results. ${ }^{37}$

The arrival of community policing in counterterrorism came on the heels of informal efforts by federal law enforcement agencies to engage with Muslim communities. Notably, federal government engagement with Muslims has a different name depending on the audience and the political context in which it is referenced. When speaking to politically conservative audiences willing to fight terrorism at the expense of civil liberties, government officials often use terms such as counterterrorism, counterradicalization, countering Islamic extremism, and fighting homegrown terrorism. $^{38}$ When speaking to Muslims and civil libertarian audiences

\footnotetext{
${ }^{34}$ Such a model would complement on-going efforts by the Muslim community to prevent youth from developing extremist views and ensure efforts to spread violent interpretations of Islamic tenets are thwarted. See Sheila Musaji, The False Claim that Muslims have No Programs to Counter Radicalization, AM. Muslim (Sept. 26, 2013), http:// theamericanmuslim.org/tam.php/features/articles/repeated-false-claim/0019755, [http:// perma.law.harvard.edu/09zCDS7MTU9/].

35 Robert Trojanowicz \& Bonnie Bucqueroux, Community Policing: How To Get STARTED 3 (1994).

36 See Wesley Skogan \& Susan Hartnett, Community Policing, Chicago Style 5 (1997); Mitch Carr, Greensboro Police Release 2012 Crime Statistics, Fox 8 WGHP, Feb. 4, 2013, http://myfox8.com/2013/02/04/greensboro-police-release-2012-crime-statistics/, [http://perma.law.harvard.edu/08kVoRGluFg/] (reporting that police chief credits community policing for drop in crime, stating that "citizens getting involved and keeping police well-informed helped stop many crimes before they could happen").

${ }^{37}$ See Murray, supra note 7, at 352; SKOGAN \& HARTNETT, supra note 36.

38 National Focus on Debate on Muslim Radicalization, Fox NEws, Mar. 6, 2011, http:// www.foxnews.com/us/2011/03/06/national-focus-debate-muslim-radicalization/, [http:// perma.cc/PQ8X-9JYF] (focusing on terms radicalization and extremism); Scott Erickson, Violent Extremism Continues to Plague Homeland Security, HeRITAGE Found. (Dec. 14, 2011), http://blog.heritage.org/2011/12/14/violent-extremism-continues-to-plague-
} 
concerned with the erosion of civil rights and liberties in the post-9/11 era, ${ }^{39}$ the government uses more soothing terms such as countering violent extremism, ${ }^{40}$ community engagement, ${ }^{41}$ community outreach, ${ }^{42}$ and, most recently, community policing. ${ }^{43}$ These variations in nomenclature are distinctions without a difference.

Irrespective of the term employed, the federal government's objectives are the same-to combat terrorism preemptively and aggressively within Muslim communities through an adversarial criminal justice system. ${ }^{44}$ While an in-depth explication of the debates surrounding these terms is beyond the scope of this Article, the following discussion provides a brief summary of each term as evidence that the government's use of milder terminology to debunk allegations of rights violations is a red herring. ${ }^{45}$ Critiques of government actions should focus on substantive practices rather than fall prey to semantic distractions.

homeland-security/, [http://perma.cc/9X4L-DNJW] (focusing on counterterrorism and violent extremism); James Jay Carafano, Steve P. Bucci \& Jessica Zuckerman, Fifty Terror Plots Foiled Since 9/11: The Homegrown Threat and the Long War on Terrorism, HERITAGE FOUND. (Apr. 25, 2012), http://www.heritage.org/research/reports/2012/04/fiftyterror-plots-foiled-since-9-11-the-homegrown-threat-and-the-long-war-on-terrorism, [http://perma.cc/6A63-ACKL] (focusing on homegrown terrorism and radicalization).

${ }^{39}$ BIPARTISAN POL'Y CTR., supra note 17, at 26.

40 Strategic Plan For Empowering Local Partners, supra note 4; see Jim Kouri, Napolitano's State, Local Cop Meeting on Extremism Vague, Say Critics, EXAMINER.COM (Jan. 18, 2012), http://www.examiner.com/article/napolitano-s-state-local-cop-meeting-onextremism-vague-say-critics, [http://perma.cc/9X7B-V6JQ] (reporting conservative members of audience complaining for absence of use of Islamic terrorism and notable emphasis on countering violent extremism).

41 Community Engagement, U.S. DEP'T OF HOMELAND SEC., http://www.dhs.gov/ community-engagement, [http://perma.cc/L6UN-ZNMF].

${ }^{42} I d$.

${ }^{43}$ U.S. DeP'T OF Just., Partnering with American Muslim Communities to Fight Crime, 4 COMM. POlicing DisPaTCH 11 (2011), available at http://cops.usdoj.gov/html/dispatch/ 11-2011/partnering-with-american-muslims.asp, [http://perma.cc/7S84-SFN2].

${ }^{44}$ Task Force on Confronting the Ideology of Radical Extremism, Rewriting the Narrative: An Integrated Strategy for Counterradicalization, THE WASH. INST. FOR NEAR E. POL'Y (Mar. 2009), available at http://www.washingtoninstitute.org/uploads/Documents/pubs/ PTF2-Counterradicalization.pdf (assessing counter-radicalization and countering extremism in the context of counterterrorism strategy) [hereinafter Rewriting the Narrative].

45 Robert S. Mueller, III, Nine Years after 9/11: Confronting the Terrorist Threat to the U.S., FBI (Sept. 22, 2010), available at http://www.fbi.gov/news/testimony/nine-yearsafter-9-11-confronting-the-terrorist-threat-to-the-u.s, [http://perma.cc/TWW6-KPM6]. 
Accordingly, Section A describes the preventive counterterrorism model that undergirds CCP. Section B demonstrates how counterradicalization, a component of counterterrorism, is disguised as community policing as a tactic to persuade otherwise skeptical Muslim communities to trust the government. And Section $\mathrm{C}$ examines the flaws in community outreach programs - the more informal predecessors to the community policing programs currently being promoted through federal grants and federal counterterrorism policy. If one focuses on what the program actually does, as opposed to what it is called, there is little that differentiates prosecution-driven counterterrorism from counter-radicalization, countering extremism, countering violent extremism, community engagement, community outreach, and community policing. ${ }^{46}$ Part III then proceeds to critique CCP as an extension of a counterterrorism strategy that subordinates Muslims based on the racialized premise that they are collectively prone to terrorism.

\section{A. Community Policing as Preventive Counterterrorism}

Counterterrorism is the most accurate descriptor of the federal government's motives and objectives in its dealings with Muslim communities in the United States, including within the community policing model. Domestically, counterterrorism is synonymous with anti-terrorism law enforcement in that it involves surveillance, investigation, and prosecution of terrorist suspects. ${ }^{47}$ In the international context, counterterrorism combines the military, law enforcement, intelligence, and, most notably, counterinsurgency tactics of counter-radicalization that disrupt terrorist groups' messaging and ability to recruit. ${ }^{48}$

Worth noting are the multiple definitions of "terrorism" within the U.S. criminal code. ${ }^{49}$ In this Article, I adopt the generic definition that an

\footnotetext{
${ }^{46} \mathrm{Id}$.

47 See, e.g., Ten Years After 9/11 Hearings, supra note 19 (testifying that "to meet the growing demand for surveillance, the Bureau has increased the number of unarmed surveillance teams by 127 percent since 2001").

${ }^{48}$ LynCH, supra note 19, at 7; William C. Banks, Providing "Supplemental Security"-The Insurrection Act and the Military Role in Responding to Domestic Crises, 3 J. Nat'1 Sec. L. \& Pol'y 39 (2009).

49 See 22 U.S.C. $\$ 2656 f(d)(2)$ (2004); 28 C.F.R. $\S 0.85$ (2012); U.S. Dep’t of Defense, Directive 2000.12 (Mar. 1, 2012), available at http://www.dtic.mil/whs/directives/corres/ pdf/200012p.pdf; see also Danielle C. Jefferis, Battlefield Borders, Threat Rhetoric, and
} 
act of "terrorism" is an attack on civilians for larger political objectives, whether couched in religious or secular narratives. ${ }^{50}$ Similar to law enforcement priorities in other criminal contexts, success in counterterrorism is measured by the number of investigations, prosecutions, and convictions. ${ }^{51}$ So long as these objectives are the primary indicia of success, community policing will remain the handmaiden of counterterrorism insofar as it is merely an additional tool in law enforcement's toolkit.

In counterterrorism efforts, federal law enforcement relies heavily on both preventive and reactive tactics. ${ }^{52}$ Preventive tactics in the post-9/11 era include: (1) surveillance of Muslims, mosques, and Muslim-owned businesses; ${ }^{53}$ (2) aggressive use of FBI sting operations employing

the Militarization of State and Local Law Enforcement, 3 NAT'L SECURITY L. BRIEF 37 , 51-53 (2012) (discussing problems with defining "terrorism"); Samuel J. Rascoff, The Law of Homegrown (Counter)Terrorism, 88 TEX. L. REV. 1715, 1718 n. 10 (2010).

50 See McCants \& Watts, supra note 8; Joshua Sinai, How to Define Terrorism, 2 PERSP. ON TERRORISM 9, 10 (2008) (citing Boaz Ganor who defines terrorism as "a form of violent struggle in which violence is deliberately used against civilians in order to achieve political goals"; also noting Ganor's assertion that "the use of 'deliberate' targeting of civilians in order to achieve political objectives is what distinguishes a terrorist act from guerrilla war fare, where military units are targeted"); Gordon H. McCormick, Terrorist Decision Making, 6 ANN. REV. OF POL. SCI. 473, 474 (June 2003) (stating "terrorism is a purposeful activity, carried out in the name of a larger political objective, regardless of the individual motives or group dynamics ...").

${ }^{51}$ Murray, supra note 7, at 352; Eric Lichtblau, F.B.I. Tells Offices to Count Local Muslims and Mosques, N.Y. TimeS, Jan. 27, 2003, http://www.nytimes.com/2003/01/28/us/threatsresponses-american-muslims-fbi-tells-offices-count-local-muslims-mosques.html, [http:// perma.law.harvard.edu/05rK4eDkZMp] (reporting the FBI's explanation for counting mosques as establishing a yardstick for the number of terrorism investigations and intelligence warrants that a field office could reasonably be expected to produce).

52 Benjamin G. Davis, A Citizen Observer's View of the U.S. Approach to the War on Terrorism, 17 TRANSNAT'L \& CONTEMP. PROBS. 465 (2008); Martin Innis, Policing Uncertainty: Countering Terror Through Community Intelligence and Democratic Policing, 605 ANNALS OF THE AM. ACAD. 222, 226 (May 2006).

${ }^{53}$ See, e.g., Matt Apuzzo \& Adam Goldman, NYPD Built Secret Files on Mosques Outside NY, ASSOCIATED PRESS, Feb. 22, 2012, http://www.ap.org/Content/AP-In-The-News/2012/ NYPD-built-secret-files-on-mosques-outside-NY, [http://perma.law.harvard.edu/ 0gCTQHTRvzU]; Matt Apuzzo \& Adam Goldman, Documents Show NY Police Watched Devout Muslims, Associated PrESS, Sept. 6, 2011, http://www.ap.org/Content/AP-In-TheNews/2011/Documents-show-NY-police-watched-devout-Muslims, [http:// perma.law.harvard.edu/0DKpxrfleGR]. See generally AP's Probe into NYPD Intelligence Operations, AssociATED PRESs, http://www.ap.org/Index/AP-In-The-News/NYPD, [http:// perma.law.harvard.edu/0bcA1Xm8giql (linking to related articles). 
informants and undercover agents; ${ }^{54}$ and (3) ideologically based public relations programs that focus on developing a counter-narrative to terrorist organizations in the purported battle for the "hearts and minds" of Muslims assumed to be intrinsically vulnerable to recruitment by terrorists. ${ }^{55}$ The last of these three preventive methods is often called counter-radicalization, countering extremism, or countering violent extremism depending on the speaker's politics and the audience. ${ }^{56}$

In contrast, reactive law enforcement tactics include investigation of criminal activity, prosecution of suspects in the process of committing or after committing a terrorist act, conviction, and incarceration. ${ }^{57}$ Notwithstanding the use of traditional reactive tactics, the federal government has stated on multiple occasions that its counterterrorism strategy is primarily preventive insofar as it seeks to prevent a terrorist act from ever occurring. ${ }^{58}$ Thus, in contrast to murder, burglary, or other forms of "traditional crimes," where law enforcement does not get involved until

54 CTR. ON LAW \& SEC., supra note 13, at 4 (finding that since 2009 nearly 50\% of terrorism cases involved informants and $15 \%$ of those informant cases can be considered sting operations); id. at 26 (reporting that in 2007 and 2009, 71\% of terrorism cases involved an informant); Josh Gerstein, Boston Marathon Bombings Reignite Debate Over Terror Stings, POLITICO, May 18, 2013, http://www.politico.com/story/2013/05/bostonmarathon-bombings-terrorism-stings-91584.html?ml=al_1, [http://perma.law.harvard.edu/ 0mSg4GBQu8r].

${ }^{55} \mathrm{LYNCH}$, supra note 19, at 3; Stevens, supra note 32; Rewriting the Narrative, supra note 44, at 16. But see McCants \& Watts, supra note 8 (critiquing the "hearts and minds" approach adopted from military counterinsurgency because there is no Muslim insurgency in the homeland).

${ }^{56}$ Rascoff, supra note 49, at 1718-19; HomELAND SEC. ADVISORY COUNCIL, supra note 4. ${ }^{57}$ Murray, supra note 7, at 353.

58 Samuel Knight, Holder Addresses U.N. Counter-Terrorism Symposium, MAIN JUST. (Sept. 19, 2011), http://www.mainjustice.com/2011/09/19/holder-addresses-u-n-counterterrorism-symposium/, [http://perma.law.harvard.edu/0C8oEs6ENSi]; Mueller, supra note 45 (stating that the FBI's number one priority is the prevention of terrorist attacks through working with state and local law enforcement to share information and conduct operations to prevent and dismantle terrorists plots); Homeland Threats and Agency Responses: Hearing Before the S. Comm. on Homeland Sec. and Governmental Aff., 112th Cong. 3, 6 (2012) (written testimony of Janet Napolitano, U.S. Dep't of Homeland Sec. Sec'y) (stating preventing terrorism is one of DHS's core missions and describing CVE and community policing as ways of achieving prevention of terrorism at the community and local level); OFFICE OF THE PRESIDENT, supra note 4, at 16 (outlining President Obama's national security strategy). 
after the criminal act has occurred, in counterterrorism they seek to predict and preempt the terrorist act. ${ }^{59}$

While the objective of preventing terrorism before it occurs invites little criticism from civil rights and liberties advocates, there is significant disagreement about the point in time at which law enforcement powers should be employed against individuals and groups. ${ }^{60}$ Critics of existing counterterrorism strategies argue that law enforcement should not be authorized to spy on or investigate any person or group without individualized suspicion of a predicate act of criminal activity. ${ }^{61}$ Until shortly after $9 / 11$, this was the dominant investigative approach because it was more rights-protective of political dissent, religious beliefs, and practices of minority groups. ${ }^{62}$ Moreover, civil liberties advocates criticize pretextual charges for violations of tax, immigration, or other nonterrorism-related laws against Muslims the government speculates will one day become terrorists based on unsavory political or religious beliefs. ${ }^{63} \mathrm{~A}$ recent poll suggests the American public is divided but marginally more concerned that the government's terrorism-related investigations will

\footnotetext{
${ }^{59}$ Murray, supra note 7, at 359 (highlighting the traditional policing model as an inflexible structure that is predominately reactive and unable to develop and sustain close working relationships with the community in helping to control crime; whereas community policing concentrates on crime prevention as its primary objective).

60 Attorney General John Ashcroft, Prepared Remarks for the U.S. Mayors Conference (Oct. 25, 2001); Harris, supra note 28, at 6.

${ }^{61}$ Tom Lininger, Sects, Lies, and Videotape: The Surveillance and Infiltration of Religious Groups, 89 IOWA L. Rev. 1201, 1203-04 (2003-2004); More About Suspicious Activity Reporting, ACLU (Jan. 18, 2013), https://www.aclu.org/spy-files/more-about-suspiciousactivity-reporting, [http://perma.law.harvard.edu/0dhA2JrdbkK]; PRICE, supra note 5, at 15 .

${ }^{62}$ Lininger, supra note 61, at 1228-29; see PRICE, supra note 5, at 20.

${ }^{63}$ Daniel C. Richman \& William J. Stuntz, Al Capone 's Revenge: An Essay on the Political Economy of Pretextual Prosecution, 105 CoLUM. L. REV. 583 (2005); Attorney General John Ashcroft, supra note 60 (comparing terrorism prosecutions to mob prosecutions, for which Robert F. Kennedy's Justice Department was "aggressive, using obscure statutes to arrest and detain suspected mobsters"); Harris, supra note 28, at 6; Press Release, U.S. Dep't of Just., Tunisian Man Charged with Visa Fraud Related to Terrorism, Intended to Remain in U.S. to Facilitate an Act of International Terrorism (May 9, 2013), available at http://jnslp.wordpress.com/2013/05/09/nationalsecuritylaw-united-states-v-abassi-s-d-n-ymay-9-2013-indictment-in-visa-fraud-case-with-allegations-of-plot-to-recruit-for-andsupport-terrorism-abroad-and-possibly-carry-out-terrorism/, [http://perma.law.harvard.edu/ 0v5kUq7h6gJ.
} 
infringe upon constitutionally protected rights than that constitutional protections will inhibit these investigations. ${ }^{64}$

But the government's claims of an ominous homegrown terrorist threat are belied by the facts. According to the New York University Center on Law and Security, counterterrorism enforcement has resulted in 1,054 terror-related cases from September 11, 2001 to September 11, 2011, of which 576 cases involved Muslim defendants. ${ }^{65}$ Since $9 / 11$, terrorism has claimed thirty-three lives in the United States compared to 180,000 murders during the same time period. ${ }^{66}$ The most common charges in terrorismrelated cases include conspiracy to commit terrorism, weapons of mass destruction possession and training, false statements to a federal agent, and providing material support to terrorist groups. ${ }^{67}$ During that same ten-year period, the federal government has prosecuted 300 counterterrorism cases involving Muslim defendants, eighty-seven percent of which resulted in conviction, mostly through plea agreements. ${ }^{68}$ Since 2009 , the government has focused on "homegrown terrorism," a racialized version of domestic terrorism with an explicit reference to Muslim terrorists ${ }^{69}$ - even though only fourteen Muslim Americans committed or were charged with terrorist crimes in 2012, down from twenty-one in 2011, twenty-six in 2010, and forty-nine in $2009 .^{70}$ Notwithstanding the potential for significant loss of

64 Washington Post Poll, http://www.washingtonpost.com/wp-srv/politics/polls/ postpoll_20130418.html, [http://perma.law.harvard.edu/0jFsyhKXSVi] (noting $48 \%$ of polled individuals noted they are more worried that the government "will go too far in compromising constitutional rights in order to investigate terrorism" compared to $41 \%$ who worry the government "will not go far enough . . . because of concerns about constitutional rights").

65 See CTR. ON LAW \& SEC., supra note 13 , at 7.

${ }^{66}$ Homegrown Muslim-American Terrorism Down Third Straight Year, DuKE TODAY (Feb. 4, 2013), http://today.duke.edu/2013/02/muslimterrorism, [http://perma.law.harvard.edu/ 0c5CTMPFqTj] (noting that since 9/11 "terrorism" has claimed 33 lives in the United States out of more than 180,000 murders during that same period). For statistics on crime reporting, see U.S. DEP'T OF JUST./FBI, Uniform Crime Reporting Statistics, http:// www.ucrdatatool.gov/Search/Crime/State/RunCrimeStatebyState.cfm.

${ }^{67}$ CTR. ON LAW \& SEC., supra note 13, at 23-24.

${ }^{68} \mathrm{Id}$.

${ }^{69}$ See Jefferis, supra note 49 (discussing rhetoric of homegrown terrorism threat).

70 See, e.g., LYNCH, supra note 19, at 10 (listing only cases involving Muslim defendants when discussing the rise of domestic radicalization and homegrown terrorism notwithstanding the documented rise in right wing, white hate groups); BIPARTISAN POL'Y CTR., supra note 17, at 12; SOUTHERN POVERTY LAW CTR., supra note 22; Charles 
life caused by a terrorist act, ${ }^{71}$ the fact remains that the risk of homegrown terrorism to public safety is not commensurate with the significant resources and political capital expended on strategies that disproportionately compromise Muslims' civil liberties. ${ }^{72}$

\section{B. Disguising Counter-Radicalization as Community Policing}

Counter-radicalization is the label used to describe the preventive component of counterterrorism strategy that confronts and challenges the ideologies used by terrorist organizations to justify the use of violence. ${ }^{73}$ Prior to the $7 / 7$ terrorist attacks in London, ${ }^{74}$ the U.S. government employed counter-radicalization primarily in the international context as a "soft" tactic

in the War on Terror and in its broader counterinsurgency strategy. ${ }^{75}$ The London bombings triggered fears in Western countries that their Muslim populations may be a figurative "ticking bomb" inside their borders. ${ }^{76}$ This led to heightened concerns with (Muslim) homegrown terrorism and

Kurzman, Muslim American Terrorism: Declining Further, DUKE TRIANGLE CTR. FOR TERRORISM \& HOMELAND SEC. 1 (Feb. 1, 2013), available at http://sites.duke.edu/tcths/ files/2013/11/Kurzman_Muslim-American_Terrorism_final2013.pdf.

${ }^{71}$ See, e.g., Katharine $\bar{Q}$. Seelye \& Michael S. Schmidt, Boston Bombing Suspect Indicted on 30 Counts, BostON GLOBE, June 27, 2003, http://www.nytimes.com/2013/06/28/us/ boston-bombing-suspect-is-indicted-on-30-counts.html?_r=0, [http://perma.law. harvard.edu/03XgXzuaa6v].

72 Faiza Patel \& Michael Price, Fusion Centers Need More Rules, Oversight, RoLL CALL (Oct. 18, 2012), http://www.rollcall.com/issues/58_30/Faiza-Patel-Michael-Price-FusionCenters-Need-More-Rules-Oversight-218271-1.html? $\mathrm{pg}=1$, [http://perma.law.harvard.edu/ 0nwBD9cVKr9]; see also StafF of S. PERMANENT SUbCOMM. ON InVEstigations, S.

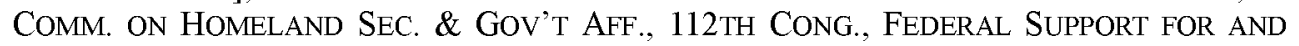
InVOLVEMENT IN STATE AND LOCAL Fusion CENTERS 3-4 (Comm. Print. 2012) (noting that the work of fusion centers appears to have violated the civil liberties of many U.S. citizens, has not produced successful counterterrorism results, and cost between $\$ 289$ million and $\$ 1.4$ billion in federal funds from 2002-2011).

73 Samuel J. Rascoff, Establishing Official Islam? The Law and Strategy of CounterRadicalization, 64 STAN. L. REV. 125, 127 (2012).

74 Alan Cowell, After Coordinated Bombs, London is Stunned, Bloodied and Stoic, N.Y. TIMES, July 7, 2005, http://www.nytimes.com/2005/07/07/international/europe/07cndexplosion.html?pagewanted=all\&_r=0, [http://perma.law.harvard.edu/0pVWdiVLFLf].

75 Dealing With Today's Asymmetric Threat to U.S. and Global Security: Employing Smart Power, CACI INT'L INC. \& U.S. NAVAL INST. 15 (Sept. 2009), available at http:// asymmetricthreat.net/docs/asymmetric_threat_3_paper.pdf (referring to internationally implemented counter-radicalization tactics as an area of defensive soft power and going on to discuss the rule of law in soft power).

76 BIPARTISAN POL'Y CTR., supra note 17 , at 7 (calling for a domestic equivalent to the State Department's Countering Violent Extremism policy "to prevent young Americans from being radicalized at home"). 
debates on how best to approach the perceived problem. ${ }^{77}$ U.S. government officials conferred with military experts ${ }^{78}$ and looked to Britain's Preventing Violent Extremism program (commonly referred to as "Prevent"), ${ }^{79}$ which emphasized empowering whomever the government deems possesses mainstream ideological alternatives to the terrorists' "us against them" narrative. ${ }^{80}$

Thus, counter-radicalization is the softer, "hearts and minds" facet of counterterrorism that complements the harsher preventive and prosecutorial tactics described above. ${ }^{81}$ Operationally, the objective is to stop people from embracing extreme beliefs (an inherently subjective and vague term) that might lead to terrorism, as well as to reduce active support for terrorist groups. ${ }^{82}$ Despite the documented rise in right wing White supremacists and militia groups, ${ }^{83}$ counter-radicalization programs in the

\footnotetext{
${ }^{77}$ McCants \& Watts, supra note 8 ("Like the United Kingdom, the United States launched its CVE enterprise in response to a perceived increase in radicalization among its Muslim citizens.").

${ }^{78} \mathrm{Id}$.

${ }^{79}$ Stevens, supra note 32 (describing Britain's 'Radical Middle Way' initiative that is aimed at "articulating a relevant mainstream understanding of Islam that is dynamic, proactive and relevant to young British Muslims"); Arun Kundnani, Spooked! How Not to Prevent Violent Extremism, INST. OF RACE REL. 10 (2009) (offering an insightful critical assessment of Britain's Prevent program based on interviews with Muslims in Britain); GREAT Britain Home Office, Prevent Strategy 25 (2011) (describing Prevent program's goal as "to prevent people from becoming terrorists or supporting terrorism").

${ }^{80}$ J. Scott Carpenter, Matthew Levitt \& Michael Jacobson, Confronting the Ideology of Radical Extremism, 3 J. NAT'L SEC. L. \& POL'Y 301 (2009); LYNCH, supra note 19, at 12; Muslims Believe US Seeks to Undermine Islam, WORLD PUB. OP. (Apr. 24, 2007), http:// www.worldpublicopinion.org/pipa/articles/brmiddleeastnafricara/346.php, [http:// www.perma.cc/0M3fpNniyDT] (finding that nearly three quarters of Muslims surveyed in four countries believed that the goal of U.S. foreign policy was to "weaken and divide the Islamic world"). But see McCants \& Watts, supra note 8 (noting that decreased sympathy for terrorist organizations does not necessarily translate into decreased support).

${ }^{81}$ Kundnani, supra note 79, at 8; Amna Akbar, Policing "Radicalization," U.C. IRVINE L. REV. (forthcoming 2014) (on file with author).

${ }^{82}$ McCants \& Watts, supra note 8; see Kundnani, supra note 79, at 20.

83 See, e.g., SOUTHERN POVERTY LAW CTR., supra note 22 (documenting 1,018 active hate groups); Sahar F. Aziz, Caught in a Preventive Dragnet: Selective Counterterrorism in a Post-9/11 America, 47 Gonz. L. Rev. 429, 448-53 (2011); Daveed Gartenstein-Ross \& Laura Grossman, Homegrown Terrorists in the U.S. and U.K., FOUNDATION FOR DEFENSE OF DEMOCRACIES 17 (Apr. 2009) (noting that America's most notorious homegrown terrorists are white males of Christian backgrounds); Amy Forliti, FBI: Minn. Raid Disrupts 'Localized Terror Attack', AssociATED PRESS (May 6, 2013), available at http:// news.yahoo.com/fbi-minn-raid-disrupts-localized-terror-attack-163339217.html, [http:// www.perma.cc/0FV2L6bfW4S]; The State of Hate: White Supremacist Groups Growing, LEADERSHIP CONF. (2009), available at http://www.civilrights.org/publications/hatecrimes/
} 
United States focus almost exclusively on challenging certain interpretations of Islam exploited by terrorist organizations to morally justify violence in furtherance of the adherents' perceived notions of justice. ${ }^{84}$

The 9/11 attacks triggered a spike in scholarship, political commentary, and policy papers analyzing the philosophical and theological underpinnings of different interpretations of Islam used to justify violence in pursuit of a political agenda. ${ }^{85}$ With that came a cottage industry of purported experts on "Islamic terrorism,"86 many of whom lack formal education or degrees in Islamic history and theology. ${ }^{87}$ Many of these experts argue for an aggressive preventive model that focuses law enforcement's attention on those holding ideologies of Islamic radical

white-supremacist.html, [http://perma.cc/8NPF-U968] (noting a 54\% increase in the number of hate groups between 2000 and 2008).

${ }^{84}$ A similar contradiction occurs in Britain where it has implemented the Prevent program, which has guided the U.S. government's countering violent extremist strategies. A. Kundnani, supra note 79, at 11 (highlighting the British government's focus on Muslim communities and disregard for right wing violent extremism); GREAT BRITAIN HOME OFFICE, supra note 79, at 40 (noting that "Prevent should be proportionate and focused. We regard this as particularly important because of the view that the last Prevent strategy was disproportionate - in particular, that it stigmatised communities, suggested that they were collectively at risk of radicalisation and implied terrorism was a problem specific to Muslim communities"); Gartenstein-Ross \& Grossman, supra note 83, at 7 (defining radicalization as "the process of adopting for oneself or inculcating in others a commitment not only to a system of beliefs, but to their imposition on the rest of society").

85 See generally Marc SAGEMEN, LeAderless JiHAD: Terror NeTwOrks IN THE Twenty-First CENTURy (2008); Quintan Wiktoriwicz, Radical Islam Rising: Muslim EXTREMISM IN THE WeSt (2005); Olivier Roy, Globalized Islam: THe SEARCH FOR A NEW UMMAH (2004); Carpenter, Levitt \& Jacobson, supra note 80, at 302.

${ }_{86}$ The title 'terrorism expert' requires seemingly minimal objective criteria, leading to many primarily white, politically conservative males monopolizing that title. With their access to contacts in mainstream media, they are able to perpetuate subordinating narratives of Muslims and terrorism unchecked. See, e.g., Benjamin Doherty, How a Clueless "Terrorism Expert" Set Media Suspicion on Muslims after Oslo Horror, EleCtronic InTIFADA (July 23, 2011), http://electronicintifada.net/blogs/benjamindoherty/how-clueless-terrorism-expert-set-media-suspicion-muslims-after-oslo-horror, [http://www.perma.cc/0cw le8QCuNq].

87 Not Qualified: Exposing the Deception Behind America's Top 25 Pseudo Experts on Islam, Muslim Public Aff. Council (Sept. 11, 2012), http://www.mpac.org/assets/docs/ publications/MPAC-25-Pseudo-Experts-On-Islam.pdf (highlighting 25 "experts" on Islam, counterterrorism, and other Muslim-related areas and the lack of training and/or knowledge these individuals have in said areas of expertise). 
extremism, ${ }^{88}$ and thus prioritizes counter-radicalization in counterterrorism strategy. ${ }^{89}$ Proponents of counter-radicalization programs assert that the government should focus on "break[ing] the radicalization cycle" promoting moderate, mainstream Muslim voices to provide choices that distract and dissuade those Muslims who may be tempted to join extremist causes. ${ }^{91}$

Such claims are problematic because scholars and policy analysts have yet to theorize adequately what causes an individual to adopt certain interpretations of Islam, deemed radical by the U.S. government, such that they become "radicalized" on a path that may lead to political violence. ${ }^{92}$ Beyond a general consensus that there is no profile or single path of "radicalization" towards violence, ${ }^{93}$ the social sciences literature is still under development and provides little insight for law enforcement's preventive and reactive counterterrorism objectives. ${ }^{94}$ Without any empirical evidence guiding law enforcement, the default strategy involves

${ }^{88}$ Guy Lawson, The Fear Factory, Rolling STONE 60 (Feb. 7, 2008); Stevens, supra note 32 (describing Britain's 'Radical Middle Way' initiative that is aimed at "articulate[ing] a relevant mainstream understanding of Islam that is dynamic, proactive and relevant to young British Muslims").

${ }^{89}$ Carpenter, Levitt \& Jacobson, supra note 80 , at 305 . Two years after this article was published, the White House issued its "Empowering Local Partners to Prevent Violent Extremism in the United States." See EMPOWERING LOCAL PARTNERS, supra note 17.

90 Carpenter, Levitt \& Jacobson, supra note 80, at 303; Adam Serwer, The Recruits, AM. Prospect, Feb. 27, 2010, at 25-26 (2010).

91 Carpenter, Levitt \& Jacobson, supra note 80, at 304 (recommending the creation of a "counterradicalization forum" where policymakers and practitioners from various countries "compare notes and best practices"); Task Force, supra note 44; Kundnani, supra note 79; Beutel, supra note 30 , at 8.

92 See, e.g., John Horgan, Discussion Point: The End of Radicalization?, START (Dec. 28, 2012), http:/www.start.umd.edu/start/announcements/announcement.asp?id=416, [http:// www.perma.cc/0iCRqo8gp8K] (arguing that radicalization does not necessarily lead to terrorism); Stevens, supra note 32, at 519; Task Force, supra note 44; BIPARTISAN POL'Y CTR., supra note 17 , at 7.

93 John Knefel, Everything You've Been Told about Radicalization is Wrong, RoLLING STONE, May 6, 2013, http://www.rollingstone.com/politics/news/everything-youve-beentold-about-radicalization-is-wrong-20130506, [http://www.perma.cc/0HPZpmm2XEs].

94 See, e.g., Horgan, supra note 92 (discussing low rate of actual terrorist acts and evidence that not all who engage in violent behavior necessarily possess radical beliefs and vice versa); Carpenter, Levitt \& Jacobson, supra note 80, at 307 (noting some terrorists are driven by feelings of exclusion from their own societies, "trapped in poverty or hopelessness within authoritarian [Middle East] regimes," or are well-educated and "live in Western democracies but struggle with issues of belonging and identity"); see also QUINTAN WIKTOROWICZ, RADICAL ISLAM Rising: MUSLIM EXTREMISM IN THE WEST 1117 (2005) (summarizing the different theories on why individuals become terrorists). 
scrutinizing Muslims who are highly religious, hold unsavory or critical political views of American domestic or foreign policy, and/or are first- ${ }^{95}$ or second-generation Muslim immigrants deemed unassimilated into the dominant Anglo-Judeo-Christian-American culture. ${ }^{96}$

Continued criticism by civil liberties advocates that the term "extremism" connotes lawful political dissent ${ }^{97}$ caused the government to adopt the term "countering violent extremism" ("CVE") 98 to emphasize its focus on those who engage or plan to engage in violence. ${ }^{99}$ Nonetheless, CVE mirrors counter-radicalization in its focus on messaging and programs designed to counter extremist narratives attractive to a small but potent group of extremists and civilian populations vulnerable to recruitment by such extremists. ${ }^{100}$ Aside from the disproven claim that Muslim communities in the United States are vulnerable to radicalization and recruitment, ${ }^{101}$ critics point out that domestic CVE is defined differently depending on the implementing agency. ${ }^{102}$ To circumvent these critiques, government officials and experts who call for counter-radicalization now use "community engagement" as the descriptor. ${ }^{103}$ Despite its innocuous name, community engagement is a counter-radicalization tactic and a

\footnotetext{
95 Jeff Kunerth, New Pew Study Finds Rise in Muslim and Hindu Immigrants to the U.S., ORLANDO SENTINEL, May 20, 2013, http://www.orlandosentinel.com/features/blogs/ religion-world/os-new-study-finds-increase-in-muslim-hindu-immigrants-20130520, 0,5651429,print.post, [http://www.perma.cc/06h6TRMf4MC].

${ }^{96}$ Gartenstein-Ross \& Grossman, supra note 83, at 26 (noting the absence of a reliable terrorist profile has caused law enforcement to stereotype immigrant and Muslim communities as potential terrorists); Chon \& Arzt, supra note 6, at 216

${ }^{97}$ Steve Gosset, ACLU Lens: Obama Plan to Fight Violent Extremism a Step in the Right Direction, But . ., ACLU (Aug. 3, 2011), http://www.aclu.org/blog/national-security/aclulens-obama-plan-fight-violent-extremism-step-right-direction, [www.perma.cc/ 0XhzAGYV2GL].

98 See EMPOWERING LOCAL PARTNERS, supra note 17.

${ }^{99} \mathrm{LYNCH}$, supra note 19 , at $20-22$.

${ }^{100} \mathrm{Id}$. at 6; BIPARTISAN POL'Y CTR., supra note 17, at 17 (accepting the claim that Muslims are vulnerable to radicalization by virtue of being Muslim).

101 Kurzman, supra note 70; Charles Kurzman, David Schnauzer \& Ebrahim Moosa, Muslim American Terrorism Since 9/11: Why so Rare?, 101 MuSLIM WORLD 464, at 478, passim (2011), available at http://sites.duke.edu/tcths/files/2013/06/ Muslim_American_Terrorism_Since_9.11_Why_So_Rare.pdf.

102 McCant \& Watts, supra note 8.

103 LYNCH, supra note 19, at 4 (arguing for coordination between engagement and combating violent extremism).
} 
preventive component of the government's prosecution-driven counterterrorism strategy. ${ }^{104}$

Critiques of the terminology of the federal government's preventive, ideologically based counterterrorism programs have led to the rise of community policing as the nom du jour. ${ }^{105}$ Among academics, the skepticism lies in the reasoning that any law enforcement program defined by the ideology of the targets is flawed by design and a nonstarter, especially in light of the FBI's egregious violations of civil liberties in the 1960 s and 1970s as part of COINTELPRO. ${ }^{106}$ At the grassroots level, skepticism among Muslim community leaders and constituents is due more to the government's glaring failure to change counterterrorism policies and practices that adversely impact or intentionally discriminate against Muslims. ${ }^{107}$ But instead of de-racializing counterterrorism strategy, the government has simply adopted a new name in an attempt to persuade Muslim communities to be more cooperative. As such, community policing is the latest example of the government's focusing on form over substance.

\section{Community Engagement, Outreach, and Community Policing}

Prior to the introduction of community policing into the post-9/11 counterterrorism discourse, "community engagement" and "community outreach" were the labels most often used to describe the interactions between Muslims and the federal agencies tasked with protecting the public

104 LYNCH, supra note 19, at 4, 18; see Kundnani, supra note 79, at 11; Working with Communities Hearing, supra note 26 (statement of Rep. McCaul) ("We must be working together [with Muslim communities] to identify and implement real solutions to counter radical violent ideology.").

105 French term of art that translates into "name of the day."

${ }^{106}$ COINTELPRO, FBI RECORDS: VAULT, http://vault.fbi.gov/cointel-pro, [www.perma.cc/ 0ZrUq1LKMZa]; see generally STEPHEN DYCUS, ET AL., COUNTERTERRORISM LAW 154-56 (2012) (discussing COINTELPRO as "secret programs" designed to "expose, disrupt, and otherwise neutralize" targeted organizations' activities and members through covert, often unlawful or otherwise improper, activities. Targeted organizations included the KKK, Black Nationalists, and the "New Left").

107 See Faiza Patel, Rethinking Radicalization, BRENNAN CTR. FOR JUST. 26-27 (2011), available at http://brennan.3cdn.net/3ff468de1211ff853e_hwm6beu15.pdf, [http:// perma.cc/0tALioSxYyR]; Kate Taylor, 14 Muslim Leaders Plän Boycott of Breakfast with Mayor, N.Y. TIMES, Dec. 28, 2011, http://www.nytimes.com/2011/12/29/nyregion/14muslim-leaders-plan-boycott-of-bloomberg-interfaith-breakfast.html, [http://perma.cc/ W3PF-PW56]. 
from civil rights violations. ${ }^{108}$ As early as 2003, the U.S. Department of Justice's Civil Rights Division, the U.S. Department of Homeland Security's ("DHS") Office for Civil Rights and Civil Liberties ("CRCL"), ${ }^{109}$ and the Federal Bureau of Investigation's Hate Crimes section ${ }^{110}$ held meetings of varying frequency with Muslim communities across the country to discuss civil rights concerns and grievances. ${ }^{111}$ As a result, civil rights outreach and engagement meetings have been narrowly limited to individual cases of discrimination or hate crimes by private actors, leaving unaddressed the broader systemic causes of both private acts of discrimination and civil liberties infringements perpetrated by the government. ${ }^{112}$

Operationally, outreach meetings are often run by low-level federal bureaucrats who set the agenda with the same pre-selected and vetted

108 U.S. DeP't of Just., Confronting Discrimination in the Post-9/11 Era: Challenges and Opportunities Ten Years Later: A Report on the Civil Rights Division's POST-9/11 CIVIL RIGHTS SuMMIT 4 (Oct. 19, 2011), available at http:// www.justice.gov/crt/publications/post911/post911summit_report_2012-04.pdf.

109 The Threat of Islamic Radicalization to the Homeland: Hearing Before the S. Comm. on Homeland Sec. and Governmental Aff., 110th Cong. 2 (2007) [hereinafter Threat of Islamic Radicalization Hearings] (statement of Michael Chertoff, Former Sec'y of Homeland Sec.) (stating "[a]n effective strategy to prevent and counter domestic radicalization requires that we not only engage these communities, but also take proactive steps to build trust and respond to issues of concern to Americans of different ethnicities, cultures, and faiths").

110 Nine Years After 9/11: Confronting the Terrorist Threat to the Homeland, Hearing Before the S. Comm. on Homeland Sec. and Governmental Aff., 111th Cong. 9 (2010), available at http://www.hsdl.org/?view\&did=17408 [hereinafter Nine Years After 9/11 Hearings] (statement of Robert S. Mueller, III, Director, FBI); Working with Communities Hearing, supra note 26 (statement of Brett Hovington Chief, Community Relations Unit, Office of Public Affairs, FBI) (describing community outreach as a tactic for preventing violent radicalization).

111 Task Force, supra note 44; but see BIPARTISAN POL'Y CTR., supra note 17, at 17 (stating that Secretary Napolitano views countering violent extremism as a more communityoriented form of counterterrorism because it provides more "tips" from within the community); see also Stevens, supra note 32, at 523 (recommending that government focus on fairer treatment, social inclusion, overcoming systemic discrimination, removing social and economic inequalities and ethnic ghettoization, and achieving greater level of integration as opposed to countering radicalization).

112 Harris, supra note 28, at 55 (describing FBI's community outreach with Muslims); U.S. Dep't of Just., Religious Freedom in Focus Newsletters, available at http:// www.justice.gov/crt/spec_topics/religiousdiscrimination/newsletters.php, [http://perma.cc/ 0m8oFf5w9Du] (reporting cases where individual Muslims' religious rights are defended); FBI, Hate Crimes Accounting: Annual Report Released (Dec. 10, 2012), available at http:// www.fbi.gov/news/stories/2012/december/annual-hate-crimes-report-released/annual-hatecrimes-report-released, [http://perma.cc/0fh3JujQ9iS] (noting that nearly all cases involve an individual victim). 
community members that purport to represent diverse Muslim communities within a particular locale. ${ }^{113}$ Members of Muslim communities are rarely consulted in the selection of community representatives to outreach meetings. ${ }^{114}$ Nor are they informed of the content of such meetings. ${ }^{115}$ Thus, many outreach meetings have evolved into superficial meet-and-greets wherein the same civil rights and liberties grievances are rehashed with minimal policy reform. ${ }^{116}$ Community leaders who are serious about effectuating policy changes usually stop attending the meetings, leaving their spots to be filled by individuals who may not have representational legitimacy or who prioritize self-promotion over the communities' collective interests. ${ }^{117}$

Because no public oversight or accountability mechanisms exist, the government and community participants have little incentive to produce tangible policy reforms that systemically change counterterrorism practices. Instead, the efforts tend to focus on eliminating the perception of disparate treatment of Muslims. ${ }^{118}$ So long as government officials can honestly claim that they met with Muslims a specific number of times, they can create the appearance of collaboration that fulfills executive directives to engage

113 Homeland SeC. Advisory Council, supra note 4, at 15; Carpenter, Levitt \& Jacobson, supra note 80 , at 322 (recommending that U.S. government only work with Muslims and Arabs who have a demonstrated track record of competing with violent and nonviolent extremists); see also Kundnani, supra note 79 (critiquing Britain's Preventing Violent Extremism program as imposing government agendas on local Muslim communities).

${ }^{114}$ Patel, supra note 107 , at 26-27.

$115 \mathrm{Id}$.

116 Id. (explaining that outreach meetings are generally perceived "as insincere" and "as a one-way means for the government to gather information about community members' religious practices").

117 Martin Innes, Policing Uncertainty: Countering Terror through Community Intelligence and Democratic Policing, 605 AnNALs AM. ACAD. OF POL. \& SOC. SCI. 222, 234 (2006) (noting difficulty of determining who really represents a community's views); Joel F. Handler, It's Not So Simple, in URGEnT Times: Policing AND Rights IN InNER-City Communities 45, 46 (Joshua Cohen \& Joel Rogers, eds., 1999) (noting in the traditional community policing context "a few activists run the show"); Sahar Aziz, The

Contradictions of Obama's Outreach to American Muslims, HuFfingTON Post, Dec. 19, 2011, http://www.huffingtonpost.com/sahar-aziz/obama-american-muslimoutreach_b_1152359.html?view=print\&comm_ref=false, [http://perma.cc/0YHCmqe1ZXr] (many leaders see such meetings as merely pro forma, check-the-box events providing political cover to the government).

118 BIPARTISAN POL'Y CTR., supra note 17, at 17-18 (stating that one of the core objectives of counter-radicalization is to address the perception of discrimination or mistreatment). 
Muslim communities. ${ }^{119}$ Moreover, the outreach meetings offer the government a rebuke to critiques that it discriminates against or does not respect the rights of Muslims. For if those allegations were true, the reasoning goes, then such meetings would not be held. Of course, this diversionary tactic misses the mark of the critiques, which focus on systemic changes in policy and practices to which the government often has no meaningful response. Thus, community outreach and engagement has been dismissed by some civil liberties advocates as a mere public relations campaign aimed to defuse allegations of religious and racial profiling. ${ }^{120}$

But the flaws of community outreach and engagement extend beyond the usual incompetence associated with some government programs or failures to implement systemic reforms. Rather, there may be a more insidious motive for outreach to Muslims. Specifically, federal agencies are looking for potential recruits to serve as informants, identifying targets for investigation and gathering intelligence about the mosques and Muslim community life in that locale. ${ }^{121}$ Since 2008 , the National Counterterrorism Center ("NCTC") and DHS have been working together to formulate a coherent strategy for combating domestic violent extremism, while CRCL has been engaging in outreach efforts with American Muslim communities to address civil liberties grievances. ${ }^{122}$ The collaboration of NCTC (an intelligence agency created to counter terrorism) with CRCL (whose

119 Working with Communities Hearing, supra note 26 (statement of Brett Hovington, Chief, Community Relations Unit, Office of Public Affairs, FBI) (describing community outreach as a tactic for preventing violent radicalization); see generally OFFICE OF THE PRESIDENT, supra note 4, at 16 (outlining President Obama's national security strategy). ${ }^{120}$ But see Hussain, supra note 15 , at 925 (critiquing the replacement of religious profiling with cultural profiling as producing the same subordinating effect); ACLU: FBI Used Outreach to Collect Info on Bay Area Muslims, KTVU \& WIRES, Mar. 27, 2012, http:// www.ktvu.com/news/news/crime-law/aclu-fbi-used-outreach-collect-info-bay-area-musli/ nFrPF/, [http://perma.cc/0MX2514LW96].

121 Ten Years After 9/11 Hearings, supra note 19 (testifying that "[t]he FBI's actions are not limited to arrests and prosecutions; they take many forms-including recruiting potential intelligence sources"); Deborah A. Ramirez, Jennifer Hoopes \& Tara Lai Quinlan, Defining Racial Profiling in a Post-September 11 World, 40 AM. CRIM. L. REV. 1195, 1231 (2003); see also Letter from Laura Murphy, Legis. Dir., ACLU, to Inspector Gen., U.S. Dep't of Just. (Apr. 26, 2012), available at http://www.aclu.org/files/assets/ letter_to_oig_re_fbi_privacy_act_violations_and_improper_targeting.pdf, [http://perma.cc/ $0 \mathrm{Vv} / \overline{\mathrm{X}} \overline{\mathrm{C}} 4 \mathrm{Msap} /]$ (requesting an investigation into abuse of community outreach to gather intelligence and coerce Muslims into serving as informants).

${ }^{122} \mathrm{LYNCH}$, supra note 19, at 10; BIPARTISAN POL'Y CTR., supra note 17, at 8; BJELOPERA, supra note 25 , at $7-8$. 
mandate is to safeguard civil rights and liberties) on counter-radicalization efforts raises legitimate concerns about the motives of government outreach programs. Similarly, some community leaders have accused the FBI and NYPD of exploiting the good faith of the Muslim communities at engagement meetings to gather intelligence for law enforcement purposes. $^{123}$

Recent FBI policies assigning U.S. Attorneys as the anchors of federal outreach at the local level also raise questions as to the relationship between counterterrorism enforcement and community engagement given that U.S. Attorneys are also the lead prosecutors of anti-terrorism laws. ${ }^{124}$ Their participation as lead conveners aggravates the inherent divergence between Muslim communities' interests in protecting their civil liberties and prosecutors' mandate to prosecute and show tangible results in the form of convictions to account for the billions of taxpayer dollars spent on counterterrorism. ${ }^{125}$

In response to these critiques, the government has begun pushing for community policing to replace community engagement and outreach as a more formal program based on models developed in the 1990s in the context of drugs, guns, and gangs. ${ }^{126}$ Community policing has become popular both among policymakers seeking to be more preventive in counterterrorism and Muslim community leaders concerned with protecting the civil liberties of their constituents. ${ }^{127}$ For government officials, "community policing" has the benefit of being a less politically charged term than "counter-radicalization" or "countering violent extremism." It has a positive connotation from a record of relative success when used to improve relations between local police and African-American communities

123 Mike German, Is the FBI's Community Outreach Program a Trojan Horse?, ACLU NATIONAL SECURITY BLOG (Feb. 13, 2013), https://www.aclu.org/blog/national-security/ fbis-community-outreach-program-trojan-horse, [http://perma.cc/0YGLuqm5Cjf/]; Harris, supra note 5 , at $140-41$.

124 See EMPOWERING LOCAL PARTNERS, supra note 17; STRATEGIC PLAN FOR EMPOWERING LOCAL PARTNERS, supra note 4; BIPARTISAN POL'Y CTR., supra note 17, at 7; see also BJELOPERA, supra note 25 , at 4-5.

125 See generally Setty, supra note 5 (discussing the application of interest convergence theory to post-9/11 national security decisions affecting the civil rights of marginalized communities).

${ }^{126}$ Brian N. Williams, Citizen Perspectives on Community Policing 17, 42 (1998).

127 Homeland Sec. Advisory CouncIl, supra note 4, at 5; OfFice OF the PResident, supra note 4, at 16 (outlining President Obama's national security strategy). 
in inner city neighborhoods. ${ }^{128}$ It also facilitates outsourcing counterradicalization objectives to nongovernmental Muslim organizations. ${ }^{129}$

Muslim-American proponents of community policing believe it offers a formal mechanism to reform selective counterterrorism practices. ${ }^{130}$ As in the community outreach context, they believe that engaging with local, state, and federal law enforcement on a regular basis builds relationships of trust. ${ }^{131}$ They feel it will give Muslim communities the necessary political access to persuade law enforcement to: (1) stop infiltrating Muslim communities and mosques with shady informants that induce, if not outright entrap, vulnerable young Muslim men; (2) withhold using their investigative authorities to open threat assessments on Muslims without individualized suspicion of criminal activity; (3) permit Muslim charities to donate humanitarian aid to Palestine, Kashmir, and other conflict zones where designated groups operate without prosecuting them for material support; and (4) refrain from exercising prosecutorial discretion based on religious practices. ${ }^{132}$ In the end, Muslim leaders in favor of community policing believe the root cause of aggressive counterterrorism tactics is law enforcement's misunderstanding of Islam, Muslims in America, and the cultural practices of the diverse ethnicities that comprise American Muslim communities. ${ }^{133}$ Thus, some Muslims believe that community policing allows the community to provide more accurate

\footnotetext{
128 WILLIAMS, supra note 126 , at 17.

129 See, e.g., Rewriting the Narrative, supra note 44, at 18; BIPARTISAN POL'Y CTR., supra note 17 , at 7; Kundnani, supra note 79 , at 10.

130 See, e.g., Beutel, supra note 30.

$131 \mathrm{Id}$. at 38 .

132 Ryan Mauro, A Window on the Muslim Brotherhood in America: An Annotated Interview with DHS Advisor Mohamed Elibiary, CTR. FOR SEC. POL'Y (Sept. 2013), http:// www.centerforsecuritypolicy.org/wp-content/uploads/2013/09/Elibiary-OccasionalPaper-1001.pdf; see Written Testimony of Asim Rehman, Federal Civil Rights Engagement with Arab and Muslim American Communities Post 9/11, U.S. Comm'n on Civ. Rts. (Nov. 9, 2012), available at http://vc-mubany.s3.amazonaws.com/files/2012-11-11-19/ MuBANY_-_USCCR_Written_Testimony_-_Nov_9_2012.pdf; Working with Communities Hearing, supra note 26 (statement of Mohamed Elibiary, The Freedom and Justice Foundation co-founder).

133 Anita Khashu, Robin Busch \& Zainab Latif, Building Strong Police-Immigrant Community Relations: Lessons from a New York City Project, VERA InSTITUTE FOR JusT. (Aug. 2005), http://www.cops.usdoj.gov/Publications/Building_PoliceImmigrant _Relations.pdf, [http://perma.cc/0kQU1q1LQbu]; Innes, supra note 11, at 231.
} 
information to law enforcement with the expectation that this will fundamentally change counterterrorism practices. ${ }^{134}$

These proponents' optimism, however, underestimates the deeply entrenched adversarial nature of America's criminal justice system, ${ }^{135}$ overlooks the long history of disparate treatment of racial and ethnic minorities, ${ }^{136}$ and misunderstands the incentive structure governing law enforcement agents and prosecutors. ${ }^{137}$ Specifically, federal agents are incentivized to recruit informants and increase the number of terrorism investigations and indictments. ${ }^{138}$ More importantly, proponents fail to recognize that there is likely to be little substantive difference between community policing and community outreach, which thus far has not been shown to empower Muslim communities or stop harsh counterterrorism practices. ${ }^{139}$ Without structural reforms to federal counterterrorism strategy and attendant practices, participants in locally based community policing are likely to be deputized as counter-radicalization agents for the federal government. As in the immigration enforcement context, ${ }^{140}$ this harms both Muslims and local police who cannot effectively combat crime without the trust of the communities they serve.

In the following discussion, I argue that absent structural reforms to counterterrorism strategy and the paramilitary culture of federal counterterrorism enforcement, ${ }^{141}$ locally based community policing will

${ }^{134}$ Beutel, supra note 30, at 10; see Ramirez, Hoopes \& Quinlan, supra note 121; Mark G. Stainbrook, Policing with Muslim Communities in the Age of Terrorism, POLICE CHIEF, Apr. 2010, at 32, available at http://www.policechiefmagazine.org/magazine/index.cfm? fuseaction=display_arch\&article_id $=2050 \&$ issue_id $=42010,[\mathrm{http}: / /$ perma.cc/ 0ZMIIBCtARu/]; David Schanzer, Charles Kurzman \& Ebrahim Moosa, Anti-Terror Lessons of Muslim-Americans, NAT'L INST. JUST. (Jan. 6, 2010).

${ }^{135}$ Gerard E. Lynch, Our Administrative System of Criminal Justice, 66 Fordham L. Rev. 2117 (1998).

${ }^{136}$ See Ramirez, Hoopes, \& Quinlan, supra note 121.

${ }^{137}$ McCants \& Watts, supra note 8.

138 Joshua Holland, Only 1 Percent of "Terrorists" Caught by the FBI are Real, SALON, (July 10, 2013), http://www.salon.com/2013/07/10/only_1_percent_of_terrorists caught_by_fbi_are_real_partner/, [http://perma.cc/0th5gfDgGyR/].

${ }_{139}$ Threat of Islamic Radicalization Hearings, supra note 109.

140 Matthew Kolodziej, Local Immigration Enforcement Harms Community Policing and Public Safety, Immigr. IMPACT (Sept. 13, 2009), http:/immigrationimpact.com/2013/09/13/ local-immigration-enforcement-harms-community-policing-and-public-safety/, [http:// perma.cc/048RznhuQcS/].

${ }^{141}$ Murray, supra note 7 , at 352 (finding that community policing works only when law enforcement agencies change their culture from an "us versus them" view of communities 
further the subordinating effects of post-9/11 counterterrorism strategies and alienate local police from Muslim communities. I also consider countercritiques in support of community policing.

\section{Critiques and Counter-Critiques of Community Policing in Counterterrorism}

CCP paradoxically causes Muslims to engage with the same entities that threaten their liberty and privacy interests, resulting in a fundamentally different power dynamic from the traditional community policing context. In traditional community policing, communities in crime-infested inner-city neighborhoods seek the assistance of local law enforcement to protect them from drug dealers, gangsters, and other violent criminals threatening the safety of their schools, businesses, and homes. ${ }^{142}$ Local law enforcement and the communities have a common interest in protecting their neighborhoods from being targeted by third-party criminals who exploit high rates of unemployment, low quality schools, and a low police presence to engage in violent crime. ${ }^{143}$ While police have historically been a source of civil rights grievances for minorities due to excessive force and pervasive racial profiling, the communities are primarily concerned with criminals potentially taking over their neighborhoods and the consequent risks to their lives. ${ }^{144}$ Thus, traditional community policing objectives merge the common interests of police and communities to eradicate crime from their neighborhoods. ${ }^{145}$ In contrast, Muslims engage with federal law enforcement and to a lesser extent with local police to protect their

to a partnership approach); Diane Cecilia Weber, Warrior Cops: The Ominous Growth of Paramilitarism in American Police Departments, CATO InST. (Aug. 26, 1999).

142 See, e.g., Michael D. Reisig, Community and Problem-Oriented Policing, 39 CRIME \& JUST. 1, 6 (2010).

143 Lara Herschberg, Ten Valuable Community Policing Strategies, GREEN HERITAGE NEWS, Jan. 21, 2003, http://greenheritagenews.com/ten-valuable-community-policingstrategies/, [http://perma.cc/0bQ5zXelpeq/] (highlighting ten policing strategies that have been recognized internationally regarding community policing).

144 James Q. Wilson \& George L. Kelling, Broken Windows, AtLANTiC OnLine (Mar. 1982), http://www.theatlantic.com/magazine/archive/1982/03/broken-windows/304465/, [http://perma.cc/KUF2-9EGE].

145 Bryan Fitzgerald, Albany Police Emphasize Stats, Community in Reducing Crime, Times Union, Jan. 7, 2013, http://www.timesunion.com/local/article/Albany-policeemphasize-stats-community-in-4 170427.php\#photo-3989677, [http://perma.cc/56XLZXX2]. 
communities from governmental infringements on their civil liberties and consequent private acts of discrimination.

Another notable difference between traditional community policing and CCP is that in the former, local police enforce traditional criminal law whereas in counterterrorism, federal agencies enforce anti-terrorism laws. ${ }^{146}$ Joint Terrorism Task Forces ("JTTFs") and state fusion centers comprised of local and federal agents prioritize preventive counterterrorism based on federal priorities. JTTFs are interagency squads led by federal agents for the purpose of investigating terrorism matters and coordinating federal counterterrorism efforts across the United States. ${ }^{147}$ JTTFs are also the primary vehicle by which the intelligence community and federal, state, local, and tribal law enforcement are integrated in domestic counterterrorism operations. ${ }^{148}$ Thus, locally operated CCP cannot be effective without inclusion of the federal government, which requires major changes to the locally driven traditional community policing model.

Accordingly, Section A challenges proposals to apply community policing programs developed in the 1990s in the context of guns, drugs, and gangs. I argue that community policing is likely to subordinate Muslim communities by bolstering implementation of adversarial counterterrorism strategies, asserting that the interests of Muslim communities in America do not converge with those of law enforcement. ${ }^{149}$ Specifically, community policing defines relations between Muslim communities and local government around federal counterterrorism priorities, props up the divisive "Good Muslim/Bad Muslim" paradigm based on an individual's willingness to accept government practices and policies, and deputizes Muslim leaders, who may unwittingly share intelligence about their communities.

\footnotetext{
${ }^{146}$ See, e.g., 18 USC $§ 2332 \mathrm{~b}$ (2008); 18 USC $\$ 2339 \mathrm{~b}$ (2009).

147 Homeland Security COUnCIL, National Strategy fOr Homeland SeCurity (Oct. 2007), available at http://www.dhs.gov/xlibrary/assets/nat_strat_homelandsecurity 2007.pdf, [http://perma.cc/0j7ZPQAJ7tn/]; Lawson, supra note 88 (finding there are over 2000 FBI agents assigned to 102 JTTFs as of 2008); PRICE, supra note 5, at 17.

148 HOMELAND SECURITY COUNCIL, supra note 147, at 50; see also Memorandum from John Ashcroft, Att'y Gen., to All U.S. Att'ys, Cooperation with State and Local Officials in the Fight Against Terrorism (Nov. 13, 2001), available at http://www.fas.org/irp/agency/ doj/agdirectives5.pdf (instructing AUSAs to work with state and local officials on countering terrorism).

${ }^{149}$ Kundnani, supra note 79, at 101.
} 
Section B then examines critiques of this Article's thesis by highlighting the four most often cited assertions by community policing supporters. First, supporters claim that engagement through community policing de-mystifies Muslims to law enforcement and thereby counters negative stereotypes of the "Terrorist Other," which they believe contribute to harsh counterterrorism tactics. Second, proponents believe community policing will de-securitize Muslim communities by shifting the focus to the underlying sociological causes of radicalization rather than reactive investigation and prosecution. Third, some community policing supporters argue that the Muslim community should engage in countering violent extremism through internal conflict resolution mechanisms that in theory are supposed to shield wayward youth from entering the criminal justice system. And finally, proponents claim the relationships built in community policing can result in incremental reforms to counterterrorism policies.

While each of these claims is reasonable in the abstract, in practice they will leave supporters disappointed. The adversarial nature of the criminal justice system, the secondary role of local police departments in a federally run counterterrorism regime, the structural incentives of federal counterterrorism agents to increase the number of investigations and prosecutions, and the political powerlessness of Muslim communities in the United States collectively minimize the likelihood that CCP will be as successful as traditional community policing is in African-American communities.

Unless federal law enforcement agencies undergo the same paradigm shift in their approaches to counterterrorism as did their local law enforcement counterparts in the $1990 \mathrm{~s}^{150}$-which is unlikely in the current political climate-Muslim communities should be wary of community policing as a velvet glove disguising the iron fist of preventive counterterrorism.

\section{A. Community Policing and Subordination Post-9/11}

Subordination theory posits that particular groups are racialized into the outsider "Other" deserving of harsh treatment by the state to protect the

\footnotetext{
${ }^{150}$ SkOGAN \& HARTNETT, supra note 36 , at 5, passim.
} 
majority from a perceived threat. ${ }^{151}$ These "out-groups" disproportionately carry the burden of distributional inequalities arising from abusive practices sanctioned by the majority. ${ }^{152}$ Calling into question the efficacy of the prevailing emphasis on individual discrimination, ${ }^{153}$ anti-subordination principles call for group-based remedies that take into account how enemy groups are racialized and constructed as outsiders. ${ }^{154}$ In the post-9/11 era, Muslims are subordinated as the racialized "Terrorist Other" targeted by aggressive national security laws and policies in response to the September 11th terrorist attacks. ${ }^{155}$ Thus, remedies should focus on systemic disparities that violate Muslims' civil liberties on a collective and not just an individual basis.

Joseph Margulies and Hope Metcalf insightfully categorize scholars' writing on post-9/11 national security law and policy into three groups: unilateralists, proceduralists, and interventionists. ${ }^{156}$ Unilateralists favor granting the executive more power during emergencies because the state's interest in survival outweighs any individual liberty interests. ${ }^{157} \mathrm{I}$ would add that this is especially so when those individuals are members of an out-group of "Terrorist Others." Proceduralists focus on bolstering structural and procedural protections in order to preserve essential American constitutional values and decrease the risk of eroding the constitutional framework. ${ }^{158}$ Proceduralists, therefore, are not as concerned with where the pendulum swings between state power and individual rights so long as the procedures that allow the pendulum to swing in either direction are

151 Gil Gott, The Devil We Know: Racial Subordination and National Security Law, 50 VILL. L. REV. 1073, 1073-75 (2005); Chon \& Arzt, supra note 6, at 220-21.

152 See Ashar, supra note 15, at 1196; Carol S. Steiker, More Wrong Than Rights, in URGENT TIMES: POLICING AND RightS IN INNER-CiTy COMMUNITIES 49, 54 (Joshua Cohen \& Joel Rogers, eds., 1999).

153 Robert S. Taylor, Hate Speech, the Priority of Liberty, and the Temptations of Nonideal Theory, 15 ETHICAL THEORY \& MORAL PRAC. 353, 357 (2012), available at http:// faculty.psdomain.ucdavis.edu/rstaylor/papers/Hate\%20Speech.pdf.

${ }_{154}$ Hussain, supra note 15 , at 934 .

155 See JOHN TEHRANIAN, WhitewAshed: AMERICAN's InVISIBLE MidDle EASTERN MINORITY 65 (2009); Chon \& Arzt, supra note 6, at 216; Susan Akram \& Kevin Johnson, Race, Civil Rights, and Immigration Law After September 11, 2001: The Targeting of Arabs and Muslims, 58 N.Y.U. ANN. SuRV. AM. L. 295, 299 (2002).

${ }^{156}$ Margulies \& Metcalf, supra note 6, at 434.

$157 \mathrm{Id}$.

${ }^{158}$ Id. at 435 . 
preserved. ${ }^{159}$ For them, protecting the rights of out-group minorities is not a concern in the short term provided that in the long run their rights can be protected after the public recovers from the expected overreaction to the national emergency. ${ }^{160}$ Hence Muslims' group and individual rights are justifiably subordinated to procedural and structural protections. ${ }^{161}$

In contrast, the interventionists argue in favor of restraining executive authority to protect civil liberties. ${ }^{162}$ Although they agree with the unilateralists and proceduralists that $9 / 11$ created a national emergency, interventionists insist that rigid constitutional interpretation favoring individual rights by an intrepid judiciary preserves America's constitutional values, especially during times of national emergency. ${ }^{163}$ Interventionists face an uncomfortable dilemma wherein they critique Bush and Obama policies as a deviation from the norm while remaining simultaneously cognizant that the pre-9/11 American criminal justice system subordinated communities of color through police brutality, the death penalty, religious intolerance, and racial profiling. ${ }^{164}$ Thus, they seek to highlight post-9/11 violations as a continuation, even if more egregious in degree, of pre-9/11 subordination of communities of color. ${ }^{165}$

Some interventionists base their critiques in immigration and alienage law, ${ }^{166}$ while others argue that racial subordination is the critical center of gravity that explains the cause and effect of post-9/11 national

${ }^{159}$ Id. at 436. But see Gott, supra note 151, at 1084 (critiquing the limitations of processbased, institutionally oriented frameworks for examining the legality of government action in national security emergencies).

${ }^{160}$ Margulies \& Metcalf, supra note 6, at 440; see generally THE HERITAGE FOUNDATION, THE Patriot ACt READER: Understanding THE LaW's Role IN THE Global War ON TERRORISM (Sept. 20, 2004), available at http://thf_media.s3.amazonaws.com/2004/pdf/ the-patriot-act-reader.pdf (providing a proceduralist's analysis in support of the PATRIOT Act by politically conservative scholars).

${ }^{161}$ Margulies \& Metcalf, supra note 6, at 440, 446-47.

162 Id. at 433 .

${ }^{163}$ Id. at 442

${ }^{164}$ Id at 445; see also Ramirez, Hoopes, \& Quinlan, supra note 121, at 1214 (noting that the onus imposed by constant suspicion by law enforcement causes targeted communities to share a massive sense of injustice and destroys relations with law enforcement).

${ }^{165}$ Margulies \& Metcalf, supra note 6, at 444-45.

166 David Cole, Enemy Aliens, 54 Stan. L. ReV. 953 (2002); Karen Engle, Constructing Good Aliens and Good Citizens: Legitimizing the War on Terror(ism), 75 U. COLO. L. REV. 59 (2004); see Ashar, supra note 15. 
security laws. ${ }^{167}$ My thesis, which falls under the latter approach, agrees with interventionist scholars that the state of pre-9/11 civil rights and liberties for communities of color left much to be desired. Thus, a critique of post-9/11 policies must be contextualized against pre-9/11 laws that disparately impacted minority groups, which laid the foundation for post-9/11 policies targeting Muslims. ${ }^{168}$ As such, I argue against CCP. In contrast to anti-drugs, -gangs, and -guns efforts where police work with communities to protect them from third-party criminals, community policing in counterterrorism co-opts Muslims into participating in a preventive counterterrorism regime that perpetuates Muslim communities' subordination in American society.

Notwithstanding official government statements that not all Muslims are terrorists, ${ }^{169}$ government practices impose racialized, groupbased social harms on Muslim communities across the country. ${ }^{170}$ Post-9/11 subordination of Muslims manifests itself in various laws, policies, and practices that effectively signal to the public that "those" Muslims are forever foreign, disloyal, and unworthy of empathy because "they" want to kill and terrorize "us" Americans, thereby relegating Muslims to secondclass citizenship. ${ }^{171}$ Pervasive government scrutiny of Muslim communities imposes significant dignitary and stigmatic costs on individuals and chills

167 Gott, supra note 151 , at 1100 .

168 Implicit in my thesis is an agreement with James Forman, Jr., who argues that the War on Terror is merely a replication of the War on Crime and, subsequently, the War on Drugs, thereby making it a racially subordinating counterterrorism strategy analogous to, and a post-9/11 extension of, the subordinating "wars" on crime and drugs but for a different target community. See generally James Forman, Jr., Exporting Harshness: How the War on Crime Helped Make the War on Terror Possible, 33 N.Y.U. REV. L. \& Soc. Change 331 (2009).

169 See, e.g., David Eldridge, Obama: America Not at War with Islam, WASH. TIMES, Sept. 8, 2012, http://www.washingtontimes.com/news/2012/sep/8/obama-america-not-warislam/, [http://perma.cc/M3W2-7AZA]; EMPOWERING LOCAL PARTNERS, supra note 17, at 2.

${ }^{170}$ Hussain, supra note 15 , at 924-25, passim.

171 See, e.g., Hussain, supra note 15, at 923 (noting history of suspicion of cultural minorities when the nation faces external threats); Margulies \& Metcalf, supra note 6, at 438-39 (highlighting that under the Obama Administration there has been a marked increase in retributive and venomous narratives about Islam and national security); David Stevens, supra note 32, at 523 (arguing that overcoming segregation, political exclusion, and discrimination are the most effective means of preventing extremism that may lead to violence). 
their willingness to engage in religious and cultural practices that define them. ${ }^{172}$

As a consequence, Muslims are pressured to downplay their religious identity while attempting to assimilate ${ }^{173}$ by adopting local accents, remaining deferential and cheerful in the face of government targeting, and engaging in hyper-patriotic acts such as displaying American flags in their homes and businesses. ${ }^{174}$ In addition, they fear becoming too active in the religious activities of a Muslim community because this will be viewed as anti-assimilationist and indicative of terrorist inclinations. ${ }^{175}$ Muslims cease engaging in identity performance expressed through public prayer, wearing headscarves, attending Muslim community events, or other activities that foster a Muslim group identity. ${ }^{176}$ Instead of being welcomed as an act of citizenship, Muslims' civic participation is discredited as disingenuous at best, or duplicitous at worst. ${ }^{177}$ In the end, Muslims are disempowered from shaping their relationships with other Americans so

172 Hussain, supra note 15, at 935-36; Ashar, supra note 15, at 1196; Chon \& Arzt, supra note 6, at 246; John Knefel, Police Spying on American Muslims is a Pointless National Shame, Rolling STONE, Mar. 11, 2013, http://www.rollingstone.com/politics/news/policespying-on-american-muslims-is-a-pointless-national-shame-20130311, [http:// perma.law.harvard.edu/07AfNBg7ioy].

173 See, e.g., Nagwa Ibrahim, The Origins of Muslim Racialization in U.S. Law, 7 U.C.L.A. J. Islamic \& Near E. L. 121, 125-29 (2008-2009); TEHRANIAN, supra note 155, at 65.

174 See, e.g., Sahar F. Aziz, From the Oppressed to the Terrorist: Muslim-American Women in the Crosshairs of Intersectionality, 9 HASTINGS RACE \& POVERTY L. J. 191, 227 (2012); John Tehranian, Selective Racialization: Middle-Eastern American Identity and the Faustian Pact with Whiteness, 40 CONN. L. REV. 1201, 1224 (2008); see also DEBORAH A. Ramirez, Sasha Cohen O'Connell \& Rabia ZaFar, DeVEloping Partnerships BetweEn LAW ENForCEMENT AND AMERICAN Muslim, ARAB, AND SikH COMMUNities: A Promising Practices Guide Executive Summary 2 (2004), available at http:// www.northeastern.edu/law/pdfs/academics/pfp-exec-sum-dnld-ver.pdf.

175 See Blocking Faith, Freezing Charity, Am. Civil Liberties Union (2009), available at http://www.aclu.org/human-rights/report-blocking-faith-freezing-charity, [http://perma.law.harvard.edu/0ARt4r2Lcjh].

176 Teresa Watanabee, Quakers Promote Immigrant Rights: Citing an Increase in Abuses Since the Sept. 11 Attacks, the Group is Asking Those Who Have Been Victimized to Step Forward, L.A. TIMES, Nov. 11, 2003, http://articles.latimes.com/2003/nov/11/local/meimmigration 11, [http://perma.law.harvard.edu/0VpBip6U8Jh]; Muslim Comty. Ass'n v. Ashcroft, Civ. No. 03-72913, ๆ 31 (E.D. Mich. Nov. 3, 2003) ("Some members have asked me and other Friday prayer leaders to avoid speaking about political issues fearing that any public discussions of controversial political issues will place more suspicion upon the [Muslim community center] and make us more likely targets of government investigation and surveillance.").

177 See, e.g., Aziz, supra note 83, at 484 (discussing congressional hearings criticizing Muslim leaders' cooperation with government). 
long as government counterterrorism strategies target and stigmatize their communities.

$\mathrm{CCP}$ aggravates these problems by presuming that Muslims, as a group, are aware of individual Muslims' terrorist inclinations or plots by virtue of sharing the same faith. Imposing guilt-by-association, law enforcement expects Muslims to know more about each other than other communities with members that have engaged in domestic terrorism. ${ }^{178}$ For example, law enforcement has yet to invest in community policing programs focused on Christian evangelical communities that support bombing abortion clinics or attacking doctors who administer abortions, ${ }^{179}$ far-right Christian communities that stockpile weapons because they wish to overthrow the government or believe the end of the world is near, ${ }^{180}$ or predominantly Anglo patriot groups that engage in violence against undocumented immigrants based on their opposition to immigration reform. ${ }^{181}$ This obvious inconsistency in the treatment of groups that have members that engage in domestic terrorism, insofar as a few members' crimes are not imputed on their demographic communities, raises the question of why law enforcement is pursuing community policing with Muslims. The answer, it appears, is that doing so offers an additional tool for law enforcement to gather intelligence in furtherance of an adversarial system that prioritizes bolstering the number of terrorism investigations, prosecutions, and convictions of Muslims in America. ${ }^{182}$

178 See Harris, supra note 5, at 134 (accepting this assumption when arguing for community policing between law enforcement and Muslim communities); Harris, supra note 28, at 4647.

179 See, e.g., Associated Press, Bobby Joe Rogers Sentences to 10 Years for Firebombing Abortion Clinic in Pensacola, HuFF. Post, Oct. 4, 2012, http://www.huffingtonpost.com/ 2012/10/04/bobby-joe-rogers-10-year-sentence-firebombing-abortion-clinic_n_

1940670.html, [http://perma.law.harvard.edu/07WtuRFuc2G]; David Barstow, An Abortion Battle, Fought to the Death, N.Y. Times, July 25, 2009, http://www.nytimes.com/ 2009/07/26/us/26tiller.html?pagewanted $=8 \&$ _r $=0 \&$ ref $=$ georgertiller, $\quad$ http:// perma.law.harvard.edu/08H4Zbz4QkU].

180 See, e.g., Nick Bunkley \& Charlie Savage, Militia Charged With Plotting to Murder Officers, N.Y. TIMES, Mar. 29, 2010, http://www.nytimes.com/2010/03/30/us/ 30militia.html?_r=0, [http://perma.law.harvard.edu/0tgHo8irVj4].

181 See, e.g., Kirk Johnson, Evidence Aside, State Lawmakers Debate 'Birther' Bills, N.Y. TIMES, Apr. 21, 2011, http://www.nytimes.com/2011/04/22/us/politics/22birthers.html, [http://perma.law.harvard.edu/0ePnEgRxcxS].

${ }^{182}$ See Murray, supra note 7, at 352; Harris, supra note 28, at 56 (noting the FBI seeks to build relationships with Muslims to exchange intelligence). 
While a substantive critique of government actions that subordinate Muslim communities as the "Terrorist Other" is beyond the scope of this Article, ${ }^{183}$ it is worth highlighting some of the most problematic practices that form the basis of most Muslims' civil liberties grievances. ${ }^{184}$ They can be categorized into three categories: religious and racial profiling, selective counterterrorism enforcement, and private acts of discrimination. First, government religious and racial profiling manifests itself in the disproportionate number of false positives of Muslim names on travel watch lists and the No Fly Lists, ${ }^{185}$ the prevalence of Muslims stopped for heightened border screening, ${ }^{186}$ and the large number of Muslims targeted for "voluntary" interviews by law enforcement and immigration agencies. ${ }^{187}$

Second, selective counterterrorism enforcement disproportionately targets Muslims for terrorism investigations and surveillance; ${ }^{188}$ tasks

183 See, e.g., Aziz, supra note 83.

${ }^{184} \mathrm{LYNCH}$, supra note 19 , at 11.

185 Latif v. Holder, 686 F.3d 1122 (9th Cir. 2012); LYNCH, supra note 19, at 22 (noting that terrorist no-fly watch lists continue to expand); Amy Pavuk, Muslim Businessman Sues Homeland Security, Says Harassed while Traveling, ORLANDo SENTINEL, Dec. 22, 2012 , http://www.orlandosentinel.com/news/local/breakingnews/os-muslim-sues-dhs-watchlist-20121222,0,4387436.story, [http://perma.law.harvard.edu/0ZFzQtgz6gf] (discussing Muslim man harassed over lengthy period of time when traveling because on watch list).

${ }^{186}$ Hussain, supra note 15, at 939-40 (highlighting case where federal agents gave coercive effect to private cultural profiling when passenger aircraft crew kicked a Muslim doctor off of the plane and another crew refused to fly unless passengers wearing traditional Afghan dress were run through a second security screening); see Susan Stellin, Security Check Now Starts Long Before You Fly, N.Y. TIMES, Oct. 21, 2013, http://www.nytimes.com/ $2013 / 10 / 22 /$ business/security-check-now-starts-long-before-you-fly.html? pagewanted=1\&_r=1\&hp, [http://perma.law.harvard.edu/02jX4JDTub3].

${ }^{187}$ Hussain, supra note 15, at 924; Shirin Sinnar, Questioning Law Enforcement: The First Amendment and Counterterrorism Interviews, 77 BROOK. L. REV. 41 (2011) (discussing "voluntary" interviews and their consequences for interviewees); ADC Requests DHS Civil Liberties Investigation Into: Operation Frontline Targeting Muslims in 2004, AL JAZEERAH Cross Cultural Understanding (Feb. 28, 2009), available at http:/www.ccun.org/ Opinion\%20Editorials/2009/February/28\%200/ADC\%20Requests\%20DHS\%20Civil $\% 20$ Liberties $\% 20$ Investigation $\% 20$ into $\% 20$ Operation $\% 20$ Frontline $\% 20$ Targeting $\% 20$ Muslims $\% 20 \mathrm{in} \% 20$ the $\% 20 \mathrm{US} \% 20 \mathrm{in} \% 202004 . \mathrm{htm}$, [http://perma.law.harvard.edu/ 0gREL8qBUXF]; Seth Cline, The 1993 World Trade Center Bombing: A New Threat Emerges, U.S. NEWS \& WORLD REP., Feb. 26, 2013, http:/www.usnews.com/news/blogs/ press-past/2013/02/26/the-1993-world-trade-center-bombing-a-new-threat-emerges, [http:// perma.law.harvard.edu/0XoHb3 $\mathrm{CDxgF}]$ (discussing a Triangle Center on Terrorism Homeland Security Study which noted Muslim Americans caused only 33 of the over 300 post-9/11 deaths by acts of political violence or mass shooting).

188 See generally AP's Probe into NYPD Intelligence Operations, supra note 53. 
dubious informants ${ }^{189}$ to prey on Muslim men with diminished mental capacity and financial problems; ${ }^{190}$ maps and spies on Muslim student associations, mosques, and Muslim-owned businesses; ${ }^{191}$ imposes special registration requirements on Muslim men between the ages of fifteen and forty-five; ${ }^{192}$ issues thousands of National Security Letters to banks and businesses that service Muslim clients; ${ }^{193}$ deports imams and religious leaders whose sermons are deemed too critical of the American government, ${ }^{194}$ and criminalizes charitable giving and political associations

189 Natapoff, supra note 13 , at 645.

190 Harris, supra note 5, at 128-29 (summarizing the FBI and NYPD's abusive use of untrained civilians as informants to spy on Muslim religious and cultural institutions); Lawson, supra note 88 (critiquing the government's use of informants to induce vulnerable defendants who posed little if any demonstrable threat to anyone or anything into government concocted terrorist plots); Associated Press, FBI: Informant Close to Entrapping Would-Be Bomber, ASSOCIATED PRESS, Feb. 4, 2013, http://bigstory.ap.org/ article/fbi-informant-close-entrapping-would-be-bomber, [http://perma.cc/9YZR-7APL]; CAIRtv, Calif. Man Arrested in Terror Plot May Need Psychiatric Evaluation, YouTuBE (Feb. 15, 2013) http://www.youtube.com/watch?v=BXjwGCvnDpY\&sns=em, [http:// perma.law.harvard.edu/0mHMT11WLcU]; TREVOR AARONSON, THE TERROR FACTORY: INSIDE THE FBI's MANUFACTURED WAR ON TERRORISM 146, 195 (2013).

${ }^{191}$ Apuzzo \& Goldman, Documents, supra note 53; Matt Apuzzo \& Charles Hawley, NYPD Infiltration of Colleges Raises Privacy Fears, AsSOCIATED PRESS, Oct. 11, 2011, http:// www.ap.org/Content/AP-In-The-News/2011/NYPD-infiltration-of-colleges-raises-privacyfears, [http://perma.cc/S6FZ-ER4E]; Matt Apuzzo, Adam Goldman \& Eileen Sullivan, NYPD 's Spying Programs Yielded only Mixed Results, ASSOCIATED PRESS, Dec. 23, 2011, http://www.ap.org/Content/AP-In-The-News/2011/NYPD-spying-programs-yielded-onlymixed-results, [http://perma.law.harvard.edu/0KMzF3YZrnc]; see also Harris, supra note 5 , at 171 .

192 See, e.g., The NSEERS Effect: A Decade of Racial Profiling, Fear, and Secrecy, RTS. WORKING GRP. (2012), available at http://www.rightsworkinggroup.org/sites/default/files/ RWGPenn_NSEERSReport_060412.pdf, [http://perma.law.harvard.edu/0AbQBZ4b4uX]; NSEERS: The Consequences of America's Efforts to Secure Its Borders, AM. ARAB ANTIDISCRIMINATION COMM. (2009), available at http://www.adc.org/PDF/nseerspaper.pdf; MOUSTAFA BAYOUMI, RACING RELIGION (2006).

193 See, e.g., Shafiqa Ahmadi, The Erosion of Civil Rights: Exploring the Effects of the Patriot Act on Muslims in Higher Education, 12 RuTGERS RACE \& L. REV. 1, 20-25 (2011); Nina J. Crimm, Muslim-Americans' Charitable Giving Dilemma: What About a Centralized Terror-Free Donor Advised Fund?, 13 ROGER WILLIAMS U. L. REV. 375, 39091 (2008).

194 E.g., Profile: Imam Fawaz Damra (PBS television broadcast July 7, 2006), http:// www.pbs.org/now/shows/227/imam-fawaz-damra.html, [http://perma.cc/5996-AL7R]; see also Jay Weaver, Federal Judge Throws Out Taliban Terror Case Against Margate Imam, MiAMI HeRALD, Jan. 17, 2013, http://www.miamiherald.com/2013/01/17/3187003/judgethrows-out-taliban-terror.html, [http://perma.law.harvard.edu/07EHNaZnwWk]; Associated Press, Former Ohio imam 's deportation to Israel angers USMuslims, TAI PEI TIMES, Jan. 11, 
through broad material-support-to-terrorism laws. ${ }^{195}$

Selective enforcement is facilitated by relaxed investigative guidelines. After 9/11, the FBI relaxed its internal investigative guidelines for counterterrorism to allow agents to conduct threat assessments without having to show a predicate act of illegal activity. ${ }^{196}$ In 2002, former Attorney General Ashcroft granted FBI agents authority to spy on religious groups and houses of worship, members of which were most likely to be Muslims. ${ }^{197}$ Further expanding investigative powers, Attorney General Mukasey in 2008 allowed agents to initiate threat assessments on anyone so long as there was a national security objective, irrespective how tenuous. ${ }^{198}$ In the few instances when agents are caught violating these lax guidelines, the Department of Justice reminds the complainant that the guidelines do not create enforceable rights for private actors. ${ }^{199}$ These policy developments demonstrate that the rhetoric of cooperation, mutual trust, or

2007, http://www.taipeitimes.com/News/world/archives/2007/01/11/2003344292, [http:// perma.law.harvard.edu/0mPrV7GBhey]; Maria L. La Ganga \& Rone Tempest, U.S. Will Drop Charges: 2 Lodi Men to Be Deported, LA TIMES, July 16, 2005, http:// www.informationclearinghouse.info/article9488.htm, [http://perma.law.harvard.edu/ 0ePBfuBWZNE]; Chon \& Arzt, supra note 6, at 225 (discussing parallels between deportation of imams post-9/11 and arrests and detentions of Buddhist priests during Japanese internment and WWII).

${ }^{195}$ See Blocking FaIth, FreEZING Charity, supra note 175.

${ }^{196}$ OfFice OF THE ATtORNEY GeN., U.S. DeP'T OF JuST., Attorney General 's Guidelines on Domestic Security Investigations (1976), reprinted in FBI Oversight: Hearings Before the Subcomm. On Civil and Constitutional Rights of the H. Comm. On the Judiciary, 95th Cong. 50-53 (1977). The requirement to show predicate acts indicative of criminal activity was imposed in the 1970s after congressional investigations uncovered a pervasive pattern of abusive and illegal domestic intelligence of dissident religious, political, and social groups. Harris, supra note 5, at 155-56. Because informants were a key component of the illegal spying on these peaceful, law-abiding groups, then-Attorney General Edward Levi established internal investigative guidelines that constrained the FBI's use of informants in political and religious groups to only those instances when the agent could provide "specific and articulable facts giving reason to believe that an individual or a group is or may be engaged in activities which involve the use of force or violence" and upon approval from FBI headquarters. THE F.B.I.: A COMPREHENSIVE GuIDE 38 (Athan G. Theoharis, ed., 1999) (reviewing the Levi Guidelines).

197 Neil A. Lewis, Ashcroft Permits F.B.I. to Monitor Internet and Public Places, N.Y. TIMES, May 31, 2002, http://www.nytimes.com/2002/05/31/national/31INQU.html, [http:// perma.law.harvard.edu/0GaeUu7txd5].

${ }^{198}$ Harris, supra note 5, at 157-58.

199 See, e.g., Office of THE Attorney Gen., U.S. Dep'T of Just., The Attorney General's Guidelines Regarding tHe Use of CONFIDENTIAL Human Sources Section I.F (2006), available at https://www.fas.org/irp/agency/doj/fbi/chs-guidelines.pdf. 
convergence of interest is a public relations strategy to offset the expected grievances arising from the attendant civil liberties violations.

Finally, the third category - private acts of discrimination-is partly a consequence of the legitimizing effect of government subordination of Muslim communities. ${ }^{200}$ As the public interprets the government's actions as part of reasonable national security policies, private actors feel justified in discriminating against Muslims in employment, housing, education, and public accommodations. ${ }^{201}$ Even worse, private actors appear to believe they are protecting public safety by vandalizing mosques with anti-Muslim graffiti and dead pigs, ${ }^{202}$ burning down children's play centers, ${ }^{203}$ and throwing firebombs to scare "those" Muslim terrorists away from "our" country. ${ }^{204}$

The effects of subordination are expressed through Muslims' palpable fears of being under constant scrutiny and consequently vulnerable

\footnotetext{
${ }^{200}$ Ramirez, Hoopes, \& Quinlan, supra note 121, at 1225; Sam Howe Verhovek, A Nation Challenged: Civil Liberties; Americans Give in to Racial Profiling, N.Y. TIMES, Sept. 23, 2001, http://www.nytimes.com/2001/09/23/us/a-nation-challenged-civil-libertiesamericans-give-in-to-race-profiling.html, [http://perma.cc/MP9V-DMSX] (reporting that " $58 \%$ of Americans surveyed backed more intensive security checks for Arabs, including those who are United States citizens, compared with other travelers; $49 \%$ favored special identification cards for such people, and $32 \%$ backed 'special surveillance' for them").

${ }^{201}$ Ibrahim, supra note 173, at 144-45.

202 See, e.g., Pamela Constable \& Tara Bahrampour, Virginia Mosques Vandalized; Area Muslim Leaders Call for Calm, Wash. Post, Sept. 15, 2012, http:// articles.washingtonpost.com/2012-09-15/local/35496968 1 first-mosque-mosqueofficials-muslim-leaders, [http://perma.law.harvard.edu/0AZqWiS $\overline{7}$ B2C/]; Pig Legs Found at Proposed Mosque Site in Ontario in Apparent Vandalism Act, ABC NEws, Aug. 11, 2012, http://abclocal.go.com/kabc/story?section=news/local/inland_empire\&id=8770248, [http://perma.cc/WDE5-VGVS]; Associated Press, Feds Charge Three Suspected White Supremacists for Tennessee Mosque Bombing, Fox News, Feb. 12, 2008, http:// www.foxnews.com/story/0,2933,330504,00.html, [http://perma.law.harvard.edu/ 0YhwHFhuwnH]; Uzma Kolsy, Eight Attacks, 11 Days, SALON.COM, Aug. 14, 2012, http:// www.salon.com/2012/08/14/eight_attacks_11_days, [http://perma.1aw.harvard.edu/ 0nqZTj7sYFB].

203 See, e.g., Press Release, U.S. Dep't of Just., Arlington, Texas, Man Sentenced to 14 Months in Federal Prison on Federal Hate Crime Conviction (Oct. 24, 2011), available at http://www.justice.gov/usao/txn/PressRel11/glaspell_sen.html, [http:// perma.law.harvard.edu/0Vyyeswkit] (noting that defendant admitted to setting fire to playground equipment at mosque, among other acts).

204 Hussain, supra note 15, at 939; Gott, supra note 151, at 1119 (citing ADC report that documented 74 cases of violence or threatened violence in schools in the first six months after September 11).
} 
to adverse government action or private acts of bias. ${ }^{205}$ Presumed to be collectively suspect, some Muslims feel they are watched closely by their co-workers or neighbors, ${ }^{206}$ spied on by informants and undercover agents, ${ }^{207}$ and targeted by high profile counterterrorism sting operations. ${ }^{208}$ These fears are validated as more Muslims experience hate crimes, school bullying, and employment discrimination. ${ }^{209}$ Residents of some towns have pressured local governments to bar mosque constructions and expansions on grounds that they are terrorist breeding centers. ${ }^{210}$ Opponents of mosque

205 See, e.g., Blocking Faith, Freezing Charity, supra note 175, at 90; Lininger, supra note 61 , at 1233-34.

206 See, e.g., Ending Racial Profiling in America: Hearing Before the Subcomm. on the Constitution, Civil Rights and Human Rights of the S. Comm. on the Judiciary, 112th Cong. (2012), http://www.judiciary.senate.gov/pdf/12-4-17RomeroTestimony.pdf [hereinafter Ending Racial Profiling Hearings] (statement of Anthony D. Romero, Executive Director, American Civil Liberties Union) (quoting a Muslim law student: "I and other community members feel betrayed by our own police force, and the fact that it's the police singling out Muslims for unfair treatment makes us all deeply concerned that other parts of society see us as suspect, too, even though we've done nothing wrong . . . My fellow students describe censoring themselves in classes to avoid saying anything that might be taken as controversial or out of the mainstream on contemporary political issues even where they should be most free-in academia. They are afraid that if they are seen as 'too Muslim' in their views, non-Muslim students and professors will see them as suspect, like the NYPD has"); Thomas Cincotta, From Movements to Mosques, Informants Endanger Democracy, PUBLIC EYE (2009), http://www.publiceye.org/magazine/v24n2/ movements-to-mosques.html, [http://perma.law.harvard.edu/0iGV8EuV5F7] (quoting Shakeel Syed, Executive Director of Islamic Shura Council in southern California: "What these [informants] have done is create an environment where every person begins to suspect the other and with the infighting and inward suspicion, the community becomes its own victim").

207 Natapoff, supra note 13, at 645, 684; Jay Weaver, Judge Throws Out Taliban Terror Case Against Margate Imam, MiAMI HERALD, Jan. 17, 2013, http://www.miamiherald.com/ 2013/01/17/3187003/judge-throws-out-taliban-terror.html\#storylink=cpy, [http:// perma.law.harvard.edu/0xhlnCL5Etp/] (reporting that the FBI sent a confidential informant to infiltrate a Miami mosque).

${ }^{208}$ See, e.g., AP's Probe Into NYPD Intelligence Operations, supra note 53.

209 See, e.g., Press Release, ISPU, The Bullying of Muslim Children is on the Rise, available at http://www.ispu.org/GetPressRelease/49/12/PRCenter.aspx, [http:// perma.law.harvard.edu/0NTgJm1Bys1/]; William B. Rubenstein, The Real Story of U.S. Hate Crimes Statistics: An Empirical Analysis, 78 TuL. L. REV. 1213, 1234-39 (20032004); Sahar F. Aziz, Sticks and Stones, the Words That Hurt: Entrenched Stereotypes Eight Years After 9/11, N.Y. CiTY L. REV. (2009); Vigil Held at Muslim Home Struck by Arson, COlumbus DispaTCH, Feb. 2, 2012, http://www.dispatch.com/content/stories/local/ 2012/02/02/vigil-held-at-muslim-home-struck-by-arson.html, [http:// perma.law.harvard.edu/0JrGtA4eCVF/].

210 See, e.g., Erica Ritz, Banning Mosques? Colo. State Senator's Remarks Have CAIR Outraged, THE BLAZE (July 17, 2012), http://www.theblaze.com/stories/2012/07/17/ banning-mosques-colo-state-senators-remarks-have-cair-outraged/, [http:// perma.law.harvard.edu/0c3URpRxNj6/]; Travis Loller, Murfreesboro Mosque Construction 
constructions unabashedly accuse Muslim citizens, many of whom were born in the area or have lived there for decades, of being terrorists. ${ }^{211}$ These contentious public debates demonstrate the extent to which the "Terrorist Other" stereotype has become a staple in American culture. ${ }^{212}$ Unsurprisingly, this leaves Muslim communities distraught at the collective guilt and scrutiny imposed on them merely because they are Muslim. ${ }^{213}$ It also leaves them feeling physically unsafe, not knowing if their neighbors' hateful speech may one day turn into physical violence. ${ }^{214}$

Will Be Stopped, Rules Chancellor Robert Corlew, HufF. Post, May 29, 2012, http:// www.huffingtonpost.com/2012/05/29/murfreesboro-mosque-const_n_1553622.html, [http://perma.law.harvard.edu/0zLYAW8GHGs].

211 See, e.g., Stephanie Condon, Christian Conservative Leader Calls for No More Mosques in U.S., CBS NEws, Aug. 12, 2010 , http://www.cbsnews.com/ 8301-503544_162-20013448-503544.html, [http://perma.law.harvard.edu/0k1QeCy9pK7/] (quoting American Family Association's Bryan Fischer: "Permits should not be granted to build even one more mosque in the United States of America . . . [because] each Islamic mosque is dedicated to the overthrow of the American government"); Mark Potok, The Patriot Movement Explodes, 145 Intelligence Report, SOUTHERN POVERTY LAW CENTER (2012), available at http://www.splcenter.org/get-informed/intelligence-report/browse-allissues/2012/spring/the-year-in-hate-and-extremism, [http://perma.law.harvard.edu/ 04snuBlrzY5]; Saeed A. Khan, Sharia Law, Islamophobia and the U.S. Constitution: New Tectonic Plates of the Culture Wars, 12 U. MD. L.J. RACE, RELIGION, GENDER \& CLASS 123 (2012).

212 CNN Wire Staff, In Battle to Build Mosque Near Ground Zero, Opponents Ask 'Why There?', CNN, July 21, 2010, http://www.cnn.com/2010/US/07/14/ new.york.ground.zero.mosque/index.html, [http://perma.law.harvard.edu/0atoSGm7aiS/] (quoting opponent of mosque construction: "It would be a terrible mistake to destroy a 154year-old building in order to build a monument to terrorism"); Edward Colimore, After Months of Controversy, a Unanimous Yes for Mosque, PHILLY.COM, Nov. 8, 2003, http:// articles.philly.com/2003-11-08/news/25461940_1_zoning-board-site-plan-mosque, [http:// perma.law.harvard.edu/0ZXdDYbyQSN/] (reporting anonymous fliers warned public that new mosque could "attract worshipers with links to terrorists"); see Chon \& Arzt, supra note 6 , at 224-25.

${ }^{213}$ Haviv Retig Gur, American Muslims on Edge in Wake of Boston Attacks, Apr. 20, 2013, http://www.timesofisrael.com/american-muslims-may-face-backlash-in-wake-of-bostonattacks, [http://perma.law.harvard.edu/0Ds59JDRqwq/].

214 Candice Ruud, Michael Russell, \& Bryan Denson, Local Mosque Gets Support as Oregon Muslims Fear Further Violence, HufFington Post, Nov. 30, 2010, http:// www.huffingtonpost.com/2010/11/30/local-mosque-gets-support_n_790098.html, [http:// perma.law.harvard.edu/0607BQblugY] (citing community concerns about additional backlash after a local Mosque was burned following the arrest of a Somali American on terrorism charges); Husna Haq, Boston Bombing: U.S. Muslims React with Fear, Frustration, and New Resolve, CHRISTIAN SCI. MONITOR, Apr. 25, 2013, http:// www.csmonitor.com/USA/Society/2013/0425/Boston-bombing-US-Muslims-react-withfear-frustration-and-new-resolve, [http://perma.law.harvard.edu/0HP955WqLC2/] (discussing the fears and backlash faced by the Muslim community following the Boston Marathon bombings). 
Meanwhile, the government has deployed substantial resources to infiltrate Muslim communities with informants and undercover agents, ${ }^{215}$ monitor Muslims' online activity and social media communications; ${ }^{216}$ and implement an aggressive, preventive strategy that measures success by the number of terrorist investigations and prosecutions. ${ }^{217}$ Cumulatively, these practices result in individual and communal self-censorship. ${ }^{218}$ Muslims become afraid to openly discuss political issues, much less vocally disapprove of government policies. ${ }^{219}$ Robust and open debates on social and political questions become glaringly absent.

More critically, Muslims are becoming suspicious of each other. ${ }^{220}$ They know there are informants in their midst, but they do not know who they are.221 To avoid getting caught in the government's counterterrorism

215 Natapoff, supra note 13, at 645, 655; see CTR. ON LAW \& SEC., supra note 13, at 26 (reporting that in 2007 and 2009, 71\% of terrorism cases involved an informant).

216 See, e.g., Chris Hawley, NYPD Monitored Muslim Students All Over Northeast, ASSOCIATED PRESS, Feb. 18, 2012, http://www.ap.org/Content/AP-In-The-News/2012/ NYPD-monitored-Muslim-students-all-over-Northeast, [http://perma.law.harvard.edu/ 0Pow918A7T5/] (reporting officers monitored student websites).

217 Selective enforcement of immigration and criminal laws against Muslims, Arabs, and South Asians was publicly announced soon after 9/11. For example, former Attorney General Ashcroft stated, "You want any population that might be thinking about committing a crime to be unsettled and distressed about it. So you have an elevated profile of enforcement. There is going to be awareness in the community that we are going to ask people to do that in such a way as to elevate a sense among those who would break the law that this isn't the thing to do." Jeffrey Toobin, Ashcroft's Ascent, NEW YORKER, Apr. 15,2002 , at 53 .

${ }^{218}$ Ending Racial Profiling Hearings, supra note 206.

219 Arun Kundnani, Missing the Best Chance to Prevent Terror Bombing, CNN, May 7 , 2013, http://www.cnn.com/2013/05/07/opinion/kundnani-terror-mosques-surveillance/, [http://perma.law.harvard.edu/0qtqZRapQw7/].

${ }^{220}$ Harris, supra note 5, at 166-67 (quoting a community leader admitting that news of an informant in the community "brought mistrust among the brothers in the mosque"); Cincotta, supra note 206.

221 See Jerry Markon, Tension Grows Between Calif. Muslims, FBI after Informant Infiltrates Mosque, WASH. POST, Dec. 5, 2010, http://www.washingtonpost.com/wp-dyn/ content/article/2010/12/04/AR2010120403710.html?sid=ST2010120404317, [http:// perma.law.harvard.edu/0ArE8USQF1/]; Matt Apuzzo \& Adam Goldman, With CIA Help, NYPD Moves Covertly in Muslim Areas, Associated Press, Aug. 23, 2011, http:// www.ap.org/Content/AP-In-The-News/2011/With-CIA-help-NYPD-moves-covertly-inMuslim-areas, [http://perma.law.harvard.edu/0Ej1xJKH12A/]. 
dragnet, they limit or stop their attendance at mosques, ${ }^{222}$ decline to donate to Muslim charities and organizations, ${ }^{223}$ and generally avoid association with Muslims. ${ }^{224}$ In the aggregate, Muslim civil society and community development is significantly stunted as communities are impeded from fully mobilizing their financial and human resources to empower themselves politically, economically, and socially. ${ }^{225}$ Consequently, they continue to be a politically marginalized minority, which only perpetuates their subordination. . $26^{2}$

In theory, community policing aims to create opportunities for government and Muslim communities to work together to address the aforementioned concerns as well as to assist law enforcement in combating terrorism. In practice, however, community policing exacerbates the subordinating effects of counterterrorism policies and practices by: (1) dividing communities between "Good Muslims" and "Bad Muslims" based on their willingness to accept community policing on the government's terms; ${ }^{227}$ and (2) deputizing community leaders as gatekeepers who share information with law enforcement about Muslim community affairs as part of a seemingly innocuous process. ${ }^{228}$

222 See, e.g., Lynn Duke, Worship and Worry; At a Brooklyn Mosque, Muslims Pray in the Shadow of Terrorism, WASH. POST, Apr. 16, 2003, at C1; Warren Richey \& Linda Feldman, Has Post-9/11 Dragnet Gone Too Far?, Christian ScI. Monitor, Sept. 12, 2003, at 1 (quoting one community leader as saying that "[s]ome people are afraid to cite verses of the Koran that include the word 'jihad' when leading prayers, because they think the government is listening"); Mosque Attendance Falls After Terrorism Arrests, NAT'L PUB. RADIO (May 30, 2007), http://Www.npr.org/templates/story/story.php?storyId=10529148, [http://perma.law.harvard.edu/04FiZoUkpBV].

223 See Blocking Faith, FreEZING Charity, supra note 175.

${ }^{224}$ Harris, supra note 5 , at 167.

225 Cincotta, supra note 206.

226 See, e.g., id.

227 For a more in-depth analysis of how post-9/11 national security policies create "Good Muslims" and "Bad Muslims," see Engle, supra note 166.

228 See Kundnani, supra note 79, at 20 (critiquing Britain's Preventing Violent Extremism program as using community gatekeepers to persuade Muslim communities to cooperate with the Prevent program by sharing information and refraining from criticizing foreign policy). But see Natapoff, supra note 13, at 645, 695 (discussing how informants are deployed to infiltrate African-American communities to purportedly save those communities from criminals, which reduces the privacy interests of these communities in pursuit of prosecutorial goals). 


\section{Propping Up the Divisive "Good Muslim" and "Bad Muslim" Paradigm}

The aftermath of the September 11th attacks created a "Good Muslim/Bad Muslim" paradigm. ${ }^{229}$ An individual willing to accept the disproportionate curtailing of Muslims' civil liberties purportedly to protect the national security of the majority is deemed a loyal, good citizen by the government. ${ }^{230}$ But those who demand equal protection under the law are deemed treacherous agitators both within and outside Muslim communities. ${ }^{231}$ Indeed, the "Bad Muslims" failure to cooperate with law enforcement ${ }^{232}$ and vociferous dissent becomes a form of transgression that leads to government and public suspicions of Muslims as having something to hide. Their participation in advocacy is associated with militant ethnics who are racialized at the bottom of the racial hierarchy. ${ }^{233}$ As such, Muslims suspicious of government motives in community policing initiatives are categorized as "Bad Muslims" whose skepticism is censured as a cause of Muslims' radicalization post-9/11.234 In contrast, the "Good Muslims" willingness to cooperate with law enforcement's CCP programs represents their attempts to assimilate so they can return to their rightful place in the White majority. ${ }^{235}$

Demanding that the government rely heavily on empowering specific Muslim organizations and individuals to provide counter-narratives in theological debates comes dangerously close to state entanglement in religion in what Sam Rascoff provocatively critiques as "establishing official Islam."236 Rascoff argues that the government's engagement with Muslims goes beyond providing a political and public relations platform for

\footnotetext{
229 Mahmood Mamdani, Good Muslim, Bad Muslim: America, the Cold War, And THE ROOTS OF TERROR (2005).

${ }^{230}$ Engle, supra note 166, at 62-63.

231 Id: Neil Gotanda, The Racialization of Islam in American Law, 637 ANNALS AM. ACAD. POL. \& SOC. SCI. 184, 194 (2011); Rascoff, supra note 73, at 173.

232 Harris, supra note 5 , at 140.

233 TEHRANIAN, supra note 155 , at 83.

${ }^{234} \mathrm{Id}$.

${ }^{235}$ Id.; Gotanda, supra note 231, at 194; Kundnani, supra note 79, at 35-38 (showing how Britain's Prevent program defines moderate Muslims as those who do not criticize British policy and extremists as those who express dissenting political views coupled with religious Salafi orthodoxy).

236 For a thorough and insightful critique of the government's potentially unconstitutional entanglement with religion arising from countering violent extremism programs, see Rascoff, supra note 73, at 162-66. See BIPARTISAN POL'Y CTR., supra note 17, at 8 (warning against government meddling in religious debates).
} 
select Muslim groups and individuals to speak out against terrorism, which most organizations have done irrespective of their relationship with the government, and comes problematically close to developing an official version of American Islam palatable to the U.S. government. ${ }^{237}$ Consequently, the government may be violating the First Amendment's Establishment Clause-enacted to prevent politicization and exploitation of religion. ${ }^{238}$ Rascoff's solution is to outsource counter-radicalization, under the guise of outreach or community policing, to private, non-governmental organizations. ${ }^{239}$ As such, Muslim communities should lead efforts to make it difficult for terrorist recruiters to cherry-pick their potentially vulnerable youth. ${ }^{240}$

Despite this seemingly benign approach, his recommendation still results in the creation of an "official Islam" due to the coercive power of the purse. With government funding, whether under the auspices of community policing or community engagement, promotion of certain interpretations of Islam will merely be effectuated through private, non-governmental actors. As noted by Arun Kundnani's field work, Britain's Prevent program demonstrates the perils of this flawed approach. ${ }^{241}$ Muslim organizations in Britain that accepted government funding in a good faith effort to protect their youth from being exploited by terrorist recruiters found themselves pressured to serve as providers of information to the police. ${ }^{242}$ Moreover,

237 But see Stevens, supra note 32, at 520-22 (showing that state sponsorship of churches in Europe leads to lower attendance and radicalization of those that remain).

${ }^{238}$ Rascoff, supra note 73 , at 130.

${ }^{239} \mathrm{Id}$. at 186-88; see also Beutel, supra note 30, at 21.

240 GREAT BRITAIN HOME OfFiCE, supra note 79, at 69 ("Schools can help to protect children from extremist and violent views in the same ways that they help to safeguard children from drugs, gang violence or alcohol."); see Rascoff, supra note 73, at 186; see also Beutel, supra note 30 , at 18.

241 Kundnani, supra note 79, at 16 (critiquing Britain's Preventing Violent Extremism program as imposing government agendas on local Muslim communities); Rascoff, supra note 73, at fn. 125, 304 (noting work of the Quilliam foundation in Britain's Prevent program); Rewriting the Narrative, supra note 44, at 5 (supporting the work of the nongovernmental Quilliam foundation in Britain, which receives government money to openly challenge extremist groups).

242 Kundnani, supra note 79, at 6; Timothy Whiteman, Birmingham: Anti-terrorist 'Community Outreach' Plan Complete Failure, EXAMINER.COM (Feb. 23, 2013), http:// www.examiner.com/article/birmingham-anti-terrorist-community-outreach-plan-completefailure, [http://perma.law.harvard.edu/0krw Vc4zZMj] (criticizing Muslim community for not informing police of defendants' travels to a training camp in Pakistan, but also recognizing community for bringing defendants back to England only to be prosecuted). 
they censored criticism of the government out of fear of losing funding or being labeled "extremists" - the very groups Muslim organizations sought to marginalize from the Muslim communities. ${ }^{243}$ As a result, a cadre of interlopers and gatekeepers formed to discipline internal dissent, cooperate with the government on the government's terms, and ultimately promote the development of an "official Islam"-using the more politically correct term "moderate Islam"244_purportedly created indigenously within Muslim communities. ${ }^{245}$ Meanwhile, participating organizations were disappointed with the government's disinterest in making structural reforms to policies and practices that contributed to discrimination against Muslims. ${ }^{246}$ Britain's experience is a cautionary note that outsourcing counterradicalization within a community policing model is likely to create a government-funded "official Islam" that subordinates Muslim communities into accepting a racialized counterterrorism paradigm.

While Rascoff's narrow critique of the First Amendment implications is useful, it misses the mark in identifying the underlying divergence of interests between Muslim communities and the federal government within a structurally prosecution-driven counterterrorism system. $^{247}$ As such, counter-radicalization programs reinforce a false dichotomy between the "Good Muslims," who actively work with the government to implement counter-radicalization programs (usually under the guise of community outreach or engagement) on the government's terms, ${ }^{248}$ and "Bad Muslims," who criticize the discriminatory effects of

${ }^{243}$ Kundnani, supra note 79 , at 16.

244 Stevens, supra note 32.

245 Beutel, supra note 30 , at 11.

${ }^{246}$ Kundnani, supra note 79 , at 17.

${ }^{247}$ Setty, supra note 5, at 192 (discussing the realist political theory prediction that interests of minority groups can be furthered only to the extent those interests are co-extensive with the self-interest of the legislator); see generally Rascoff, supra note 73.

248 Much of the government's influence in propping up "good Muslims" is manifested in private conversations among (predominantly male) Muslim leaders who invoke pragmatic arguments to dissuade those deemed to be a problem by the government from being too critical of the government lest they invite collective punishment against the entire community. See Anti-CAIR, http://www.anti-cair-net.org/, [http://perma.law.harvard.edu/ OfrQDrqjPx] (site dedicated to counter-acting and speaking against CAIR, which it claims is an organization founded by terrorists); Joseph Abrams, House Leaders Wary of CAIR After FBI Shuns Islamic Advocacy Group, Fox NEwS, Feb. 3, 2009, http:// www.foxnews.com/politics/2009/02/03/house-leaders-wary-cair-fbi-shuns-islamicadvocacy-group/, [http://perma.law.harvard.edu/0w7Gkbq5D61] (stating the FBI and 
counterterrorism practices, ${ }^{249}$ refuse to engage with government unless on terms that meaningfully protect civil rights and liberties, ${ }^{250}$ vehemently disagree with American foreign policy, and/or practice a stringent form of Islam. ${ }^{251}$ This co-opts Muslim communities through divide-and-conquer tactics discussed in more detail in Part IV. ${ }^{252}$

Some well-meaning community leaders embrace community policing, believing it will end negative government scrutiny manifested in disproportionate surveillance, investigations, and prosecutions of Muslims. ${ }^{253}$ Supporters view community policing as an opportunity to engage with law enforcement to communicate the communities' concerns about systemic and individual violations of civil liberties and rights. ${ }^{254}$ And, they believe, by de-mystifying Muslims in the eyes of law enforcement, civil liberties violations will consequently decrease. ${ }^{255}$

But their optimism overlooks decades of subordination experienced by other minority communities at the hands of the U.S. government. Despite the passing of more than a hundred years since the end of slavery, followed by decades of Jim Crow laws, African Americans are still disproportionately prosecuted and incarcerated in America's criminal justice

several Congressional members believe CAIR has ties to terrorist organizations); see also LYNCH, supra note 19, at 11 (noting the perceptions that community engagement is simply counterterrorism in disguise).

249 Kundnani, supra note 79, at 35-38 (showing how Britain's Prevent program defines moderate Muslims as those who do not criticize British policy and extremists as those who express dissenting political views coupled with religious Salafi orthodoxy).

${ }^{250}$ Samantha Henry, NJ Finds NYPD Muslim Surveillance is Legal, YAHOO NEwS, May 24, 2012, http://news.yahoo.com/ap-nj-finds-nypd-muslim-surveillance-legal-183326533.html, [http://perma.law.harvard.edu/0cL2rAFfSzk].

251 Joseph Abrams, FBI Cuts Ties with CAIR Following Terror Financing Trial, Fox NEwS, Jan. 30, 3009, http://www.foxnews.com/politics/2009/01/30/fbi-cuts-ties-cair-followingterror-financing-trial/\#ixzz2LNkBnjZc, [http://perma.law.harvard.edu/0vrZeRQTWFP]; Scott Shane, CAIR on Hot Seat at Hearing on U.S. Muslims, N.Y. TIMES, Mar. 11, 2011, http://www.nytimes.com/2011/03/12/us/politics/12muslims.html?_r=0, [http:// perma.law.harvard.edu/0HmFhiW1D9n].

${ }^{252}$ Carpenter, Levitt \& Jacobson, supra note 80, at 317.

253 See, e.g., Aziz Z. Huq, Legitimacy and Deterrence Effects in Counterterrorism Policing: A Study of Muslim Americans, 44 LAW \& SOC'Y REV. 365 (2010).

254 Alexis Taylor, Police Engage Faith Leaders in Crime Fight, AFRO (Jan. 9, 2013), http://www.afro.com/sections/news/Baltimore/story.htm?storyid=77167, [http:// perma.law.harvard.edu/0vcWXccY2sL]. See also Ramirez, Hoopes, \& Quinlan, supra note 121 , at 1196 .

255 See, e.g., Huq, supra note 253. 
system, adversely impacted by voter registration laws, and underrepresented in electoral politics. ${ }^{256}$ Similarly, Asian Americans continue to be stereotyped as the model minority whose national loyalties are nonetheless suspect, ${ }^{257}$ and their communities are essentialized as cutthroat overachievers. ${ }^{258}$ Latinos are presumed to be illegally in the United States, notwithstanding many are descendants of families who lived in the southwestern states prior to U.S. annexation. ${ }^{259}$ As a result, aggressive immigration enforcement targets Latino communities and devastates hundreds of thousands of families. ${ }^{260}$

To a large extent, these disparate results are a product of the same racialized adversarial criminal justice system that applies to counterterrorism. Thus, Muslims' belief that they are somehow immune from the subordination experienced by other minority communities assumes a fictional exceptionalism. ${ }^{261}$ Indeed, the twelve years since the $9 / 11$ attacks show that Muslims in the United States are not only experiencing subordination in various settings, but they also have been relegated to the lower tier of the "racial hierarchy." 262 For example, the government targets Muslims based on its assumption that certain national origins from which there is an $\mathrm{Al}$ Qaeda presence are suspect for purposes of detention,

${ }^{256}$ See Natapoff, supra note 13, at 645, 651, 692.

${ }^{257}$ See Chon \& Arzt, supra note 6, at 217 (discussing suspicions of Japanese Americans as having a propensity for espionage and sabotage); Leti Volpp, The Culture of Citizenship, 8 TheoreTiCAl InQ. 571, 579 (2007); see, e.g., Bill Mears, Deal in Wen Ho Lee Case May be Imminent, CNN, May 22, 2006, http://www.cnn.com/2006/LAW/05/22/ scotus.wenholee/, [http://perma.law.harvard.edu/0KmTXbRg9Mw].

258 See, e.g., Keith Aoki, "Foreign-ness" \& Asian American Identities: Yellowface, World War II Propaganda, and Bifurcated Racial Stereotypes, 4 ASIAN PAC. AM. L.J. 1, 11 (1996) (discussing connotations of "model minority" myth, including that Asian Americans assimilate well and are aggressive over-achievers); Pat K. Chew, Asian Americans: The "Reticent" Minority and Their Paradoxes, 36 WM. \& MARY L. REV. 1, 55 (1994).

259 Kevin Johnson, The Case Against Racial Profiling in Immigration Enforcement, 78 WASH. U. L.Q. 675, 685-88 (2000).

${ }^{260}$ Ashar, supra note 15.

${ }^{261}$ M.A. Muqtader Khan, American Exceptionalism and American Muslims, 10 REV. FAITH \& INT'L AFFS. 59-65 (2012) (describing some American Muslims' belief that they are set apart from the greater Muslim community in a positive way).

262 See generally Kevin R. Johnson, The End of "Civil Rights" As We Know It?: Immigration and Civil Rights in the New Millennium, 49 U.C.L.A. L. REV. 1481 (2002); Natsu Taylor Saito, Symbolism Under Siege: Japanese American Redress and the "Racing" of Arab Americans as "Terrorists", 8 ASIAN L.J. 1 (2001); Natsu Taylor Saito, Alien and Non-Alien Alike: Citizenship, "Foreignness," and Racial Hierarchy in American Law, 76 OR. L. REV. 261 (1997). 
deportation, interrogation, and exclusion from the United States. ${ }^{263}$ Their targeted status fuses national origin, religion, and race such that an Arab, Middle Easterner, or Muslim is presumed to be a terrorist or affiliated with terrorists. $^{264}$ As aptly noted by Leti Volpp, the consequence is a near impossibility "to separate who is likely to engage in terrorism from assumptions about that person's race, religion, and national origin." 265

The government uses community outreach and CCP to manipulate these intracommunity divisions. It promotes Muslims seeking to return to their perceived pre-9/11 White privileged status and thus willing to support engagement with government to prove their loyalty, regardless of its efficacy. Meanwhile, Muslims who engage only on terms that protect the communities' civil rights and produce tangible policy reforms are ostracized as troublemakers. ${ }^{266}$ Manipulation of the "Good Muslim/Bad Muslim" paradigm is facilitated by entrapment laws and internal investigative guidelines, which favor the government. ${ }^{267}$ The government, therefore, is able to wield significant power, in comparison to politically powerless Muslim communities, ${ }^{268}$ to persuade some Muslims that cooperating and sharing information is in their best interest. ${ }^{269}$

2. Deputizing Community Leaders to Gather Intelligence on Muslims

While law enforcement should seek information directly related to a known terrorist plot, law enforcement continues to seek information about lawful activities that facilitate their mapping of Muslim mosques,

263 See, e.g., Volpp, supra note 257, at 581; Ashar, supra note 15, at 1188 (noting the author's client was arrested for discernible reason other than the fact he was brownskinned, Muslim, and present at a Brooklyn mosque at the time of INS sweep).

264 See generally Aziz, supra note 174; Ibrahim, supra note 173.

${ }^{265}$ Volpp, supra note 257, at 582.

${ }^{266}$ See Tehranian, supra note 174 , at 1229.

${ }^{267}$ Harris, supra note 5, at 141-68.

268 Id., at 186 (admitting that law enforcement has little incentive to keep promises to restrain its authorities because the law grants it the power to do as it pleases). See also Gurpreet Mahajan, Multiculturalism in the Age of Terror: Confronting the Challenges, 5 POL. STUD. REV. 317, 325 (2007) (arguing that minorities must constitute a certain percentage of the population in order for their interests to be advanced since only then will they be able to "tilt the balance in favour of or against a political party").

${ }^{269}$ See, e.g., German, supra note 123. 
community organizations, student organizations, and leadership. ${ }^{270}$ Thus, $\mathrm{CCP}$ is about more than stopping terrorist plots, which occurs without $\mathrm{CCP}$ as Muslim communities have the same public safety interest in stopping terrorism as any other community. ${ }^{271}$ Rather, community policing offers law enforcement access to personal and detailed information about Muslim communities' affairs without the political risk of untrained informants being discovered or going rogue. ${ }^{272}$ But as law enforcement solicits information from Muslims, officers still send informants into communities in search of existing plots and at times concoct plots with mentally unstable young men with radical political views. ${ }^{273}$ Cooperating community leaders are then used to legitimize CCP and assist with crisis management when law enforcement is caught abusing rights caused by underlying counterterrorism strategies. ${ }^{274}$

Informants have been a critical tool for combating organized crime, drug dealing, and gangs. ${ }^{275}$ However, the use of informants in counterterrorism has increased at a troubling rate since $9 / 11 .{ }^{276}$ Compared to

${ }^{270}$ See NYPD's Muslim mapping project where police were tasked to "[i]dentify and map ethnic residential concentrations within the Tri-State area," "[i]dentify and map ethnic hot spots," and "Monitor current events," NYPD InTELLIGENCE Division, Powerpoint, available at http://demographicsunited.files.wordpress.com/2011/10/nypd-powerpointracism.pdf; see also Racial Mapping: The Secret Behind the FBI's Invasive Program, HuFFINGTON POST, Feb. 13, 2013, http://www.huffingtonpost.com/2013/02/13/racialmapping-fbi-secret-program_n_2679367.html, [http://perma.law.harvard.edu/ 0bYjNVZNNSb]; Richard Winton, Teresa Watanabe \& Greg Krikorian, LAPD Defends Muslim Mapping Effort, L.A. TIMES, Nov. 10, 2007, http://www.latimes.com/news/local/lame-lapd10nov 10,0,3960843.story, [http://perma.cc/E77G-DP33]; Associated Press, supra note 190; PRICE, supra note 5, at 7-8.

271 See, e.g., Steve Benen, Meet Aliou Niasse, WaSh. Monthly, May 5, 2010, http:// www.washingtonmonthly.com/archives/individual/2010_05/023656.php, [http:// perma.law.harvard.edu/n0cuKNpZv93] (profiling Muslim who reported Times Square bombers to police).

${ }^{272}$ Cincotta, supra note 206 (discussing Craig Monteih case); Natapoff, supra note 13, at 645,649 .

273 See Jean-Paul Brodeur, High and Low Policing in Post-9/11 Times, 1 Policing 25, 35 (2007); see CTR. ON LAW \& SEC., supra note 13, at 26 (reporting that in 2007 and 2009, $71 \%$ of terrorism cases involved an informant); Associated Press, supra note 190 (noting the FBI's concern that its informant was entrapping a young Muslim male target who was mentally unstable).

${ }^{274}$ Cincotta, supra note 206.

${ }^{275}$ Natapoff, supra note 13 , at 645,661 .

${ }^{276}$ E.g., Cincotta, supra note 206; but see Natapoff, supra note 13, at 645, 656 (noting that nearly every drug case involves an informant, making informants a staple of the War on Drugs). 
1,500 informants in 1975 and 2,800 in 1980, investigative reports indicate that there are now approximately 15,000 FBI paid informants, whose tasks are driven to a large extent by racial and religious profiling. ${ }^{277}$ Many of the informants are explicitly tasked to spy on and infiltrate American Arab and Muslim communities. ${ }^{278}$

For example, the New York Police Department ("NYPD") sent agents and informants to New York City mosques, restaurants, and other Muslim-owned businesses viewed as "security risks" for "endorsing conservative religious views or having devout customers." 279 The NYPD explicitly used "ethnic orientation, leadership and group affiliations" to mark fifty-three "mosques of concern."280 According to the Associated Press, the documents "paint the clearest picture yet of how the past decade's hunt for terrorists also put huge numbers of innocent people under scrutiny as they went about their daily lives in mosques, restaurants, and social groups." 281 When coupled with multiple discoveries that informants have induced young Muslim men with diminished mental capacity or financial problems toward violence, it should come as no surprise that some Muslim communities are distrustful of state and federal law enforcement agencies' overtures to engage in community policing. ${ }^{282}$ Indeed, some community

\footnotetext{
277 Trevor Aaronson, The Informants, MotHeR Jones (Sept./Oct. 2011), http://www. motherjones.com/politics/2011/08/fbi-terrorist-informants, [http://perma.law.harvard.edu/ 0MsNufEoiph]; see also Ten Years After 9/11 Hearings, supra note 19 (testifying that "[w]ith the expanded national security mission, the need for and value of [human intelligence] in understanding our adversaries and developing the threat picture has increased significantly").

${ }^{278}$ Harris, supra note 5, at 140.

279 Apuzzo \& Goldman, Documents, supra note 53; see Larry Neumeister \& Eileen Sullivan, NYPD Defends Spying on Muslims for Terror Threats, Associated PRESs, Feb. 4, 2013, http://www.pottsmerc.com/article/20130204/NEWS04/130209748/nypd-defendsspying-on-muslims-for-terror-threats?mobredirect=true\#full_story, [http:// perma.law.harvard.edu/0apoLhyFJHw].

${ }^{280}$ Apuzzo \& Goldman, Documents, supra note 53 (referencing 2006 NYPD documents).

${ }^{281}$ Id

282 See, e.g., Samantha Henry, NJ FBI: NYPD Monitoring Damaged Public Trust, ASSOCIATED PRESS, Mar. 7, 2012, http://www.ap.org/Content/AP-In-The-News/2012/NJFBI-NYPD-monitoring-damaged-public-trust, [http://perma.law.harvard.edu/ 0xcSNxag39h] ("The monitoring of Muslims in Newark and across the state has damaged the public's trust in New Jersey law enforcement and jeopardized some of the relationships agents had sought to build in the community since 9/11, said Michael Ward, agent in charge of the FBI's Newark division.").
} 
members suspect community policing is a means of recruiting Muslims as informants, whether for pay or based on informal relationships. ${ }^{283}$

Even if such suspicions are misplaced, something more insidious may be occurring. Under the guise of collaboration and relationshipbuilding in community policing, community leaders are more likely to provide information about their communities' lawful activities than would otherwise be available to law enforcement. ${ }^{284}$ As law enforcement officials develop personal relationships with community leaders, they are able to exploit those relationships to solicit detailed information about Muslim communities. ${ }^{285}$ The information is added to intelligence databases, used to map communities, or used for prosecutorial purposes without the community leaders' knowledge. In effect, the community leader becomes an unwitting informant. ${ }^{286}$ Thus, community policing normalizes and destigmatizes invasion of the privacy of peaceful Muslim communities ${ }^{287}$ by reframing it as benign "information sharing" between law enforcement and their constituents. ${ }^{288}$

${ }^{283}$ Associated Press, supra note 190; Innes, supra note 117, at 232 (noting that community engagement units are often established to develop a "community intelligence feed" about communities of interest to the police). See also, Matt Apuzzo \& Adam Goldman, NYPD Designates Mosques as Terrorism Organizations, AssOCIATED PRESS, Aug. 28, 2013, http:// bigstory.ap.org/article/nypd-designates-mosques-terrorism-organizations, [http:// perma.law.harvard.edu/0bevvKEUuKA].

284 See Jude McCulloch, Blue Army: Paramilitary Policing in Victoria (2001).

285 See BJELOPERA, supra note 25, at 7 (citing meetings with Muslim leaders just before arrest in terrorism plot as evidence of effectiveness of community outreach/policing).

286 "We're spending more money on outreach . . . so we can say: 'Please help us. Please look for people who are turning away from institutions of extremism. Please be our eyes and ears." Karen DeYoung, Distrust Hinders FBI in Outreach to Muslims, WASH. POST., Feb. 8, 2007, http://www.washingtonpost.com/wp-dyn/content/article/2007/02/07/ AR2007020702314p_f.html, [http://perma.cc/AA9X-DK7R] (quoting Philip Mudd, Deputy Dir of the FBI's Nat'l Sec. Branch); see also Cincotta, supra note 206; Lininger, supra note 61, at 1231 (highlighting the FBI's bad faith in claiming the mapping of mosques is to protect Muslims from hate crimes rather than set targets for surveillance and investigation).

287 For a critique of the adverse impact of snitching on racial minority communities, see Natapoff, supra note 13 , at 645.

288 Raymond Kelly, Safeguarding Citizens and Civil Liberties, 59 RuTGERS L. REV. 555 (2006) (highlighting the importance of information sharing in a post-9/11 world); Murray, supra note 7 , at 347,357 (noting that community policing works best when structured to encourage information sharing from the community); HOMELAND SEC. ADVISORY COUNCIL, supra note 4, at 20. 
Such concerns came to light when the NYPD engaged in community outreach programs to purportedly build relationships of trust with Muslim communities while simultaneously engaging in mass surveillance of Muslim college students across the East Coast, mosques in the Tri-State area, and Muslim-owned businesses. ${ }^{289}$ In 2007, the NYPD had at least twenty employees liaising with Muslim communities to "make inroads and foster trust in the city's kaleidoscopic and widening sea of immigrants, many of them distrustful of the police."290 It also hired two Muslim civilians as liaisons "to do outreach and to train the department's officers in matters of cultural sensitivity." 291 Around the same time, the NYPD reported weekly on activities of Muslim Student Association ("MSA") activities at universities on the East Coast. ${ }^{292}$ The reports detailed events sponsored by MSAs, biographies of Muslim speakers, and contents of presentations at the monitored events. ${ }^{293}$ It produced weekly intelligence reports documenting conversations that confidential informants and undercover agents had with Muslim congregants at mosques and the contents of sermons. ${ }^{294}$ These mass surveillance efforts were ongoing when the Associated Press published a series of investigative reports exposing the extent of the NYPD's mass surveillance of Muslim communities. ${ }^{295}$ Presumably, these activities remain ongoing, as suggested by a lawsuit filed by Muslims alleging that the NYPD's selective and mass surveillance of

289 See generally AP's Probe Into NYPD Intelligence Operations, supra note 53.

290 Cara Buckley, New York City Police Seek Trust Among Immigrants, N.Y. TIMES, May 31 , 2007, http://www.nytimes.com/2007/05/31/ny region/3 loutreach.htm1? pagewanted=print, [http://perma.cc/S59Y-SNJX]; Neumeister \& Sullivan, supra note 279.

${ }^{291}$ Buckley, supra note 290.

292 Hawley, supra note 216.

293 NYPD, Weekly MSA Report (Nov. 22, 2006), available at http://hosted.ap.org/specials/ interactives/documents/nypd-msa-report.pdf.

294 Neumeister \& Sullivan, supra note 279 (explaining civil rights lawyers' request that judge stop NYPD from routinely observing Muslims in restaurants, bookstores and mosques); NYPD, Secret Intelligent Note (Oct. 16, 2006), available at http://hosted.ap.org/ specials/interactives/documents/nypd/nypd_planecrash.pdf; Harris, supra note 5, at 138.

295 Tom Hays, Undercover Cop Unraveled NJ Terror Plot, Associated PRESS, June 8, 2010, available at http://www.huffingtonpost.com/2010/06/08/undercover-copunraveled_n_604094.html (undercover Muslim officer one of 1,000 officers assigned to NYPD counterterrorism duty, including a cadre of undercovers on assignments deep within Muslim communities). 
mosques, Muslim-owned businesses, and Muslim student associations violated their First and Fourteenth Amendment rights. ${ }^{296}$

The circumstances surrounding information sharing in $\mathrm{CCP}$, therefore, cannot be ignored. Since 9/11, an elaborate network of intelligence databases at the local, state, and federal level has been created to store petabytes of information purportedly related to national security. ${ }^{297}$ Much of this information comes from heightened scrutiny of Muslim individuals, mosques, and Muslim communities' affairs as part of the preventive counterterrorism strategy. Indeed, fusion centers in Texas and Missouri were discovered to be creating "suspicious activity reports" that concluded that Muslim civil rights organizations and civic activities pose a potential threat to national security. ${ }^{298}$ Similarly, mosques in New York City, Orange County, Albany, and other locales have discovered they are under

296 First Amended Complaint, Hassan et al. v. City of New York, 2:12-cv-03401-SDWMCA (D.N.J. Oct. 3, 2012), available at https://d3n8a8pro7vhmx.cloudfront.net/ muslimadvocates/pages/2 16/attachments/original/1363890067/10_FIRST_AMENDED COMPLAINT.pdf?1363890067; see also Complaint, Raza v. City of New York, No. 1:13cv-03448 (E.D.N.Y. Jun 18, 2013), available at https:/www.aclu.org/national-security/ raza-v-city-new-york-complaint (which the ACLU and CLEAR filed in June 2013 with similar claims).

297 See Federal Government Intelligence Sharing with State, Local and Tribal Law Enforcement: An Assessment Ten Years After 9/11: Hearing Before the Subcomm on Counterterrorism and Intelligence of the H. Comm. of Homeland Sec., 112th Cong. (2012), available at http://www.fbi.gov/news/testimony/intelligence-sharing-with-federal-stateand-1ocal-1aw-enforcement-10-years-after-9-11, [http://perma.law.harvard.edu/ 0jsnk9Am9cg] (statement of Eric Velez-Villar, Assistant Dir., Directorate of Intelligence, FBI) (testifying "we also recognize that the violent extremism threat may be first identified within our communities by state, local, or tribal law enforcement. As a result, we have taken numerous proactive steps in the past year to develop a more robust information sharing capacity with all federal, state, local, and tribal law enforcement partners"); Kelly, supra note 288, at 558; Editorial Board, Too Many Government Secrets, WASH. PosT, Dec. 25, 2012, http://www.washingtonpost.com/opinions/too-many-government-documents-arekept-secret/2012/12/25/ee9a922c-449e-11e2-8e70-e1993528222d_story.html, [http:// perma.law.harvard.edu/0ZVs5ciRi7K]. See generally PRICE, supra note 5 (describing the development of fusion centers and JTTFs, and the variable and generally irrelevant data they have gathered).

298 See, e.g., StafF of S. Permanent Subcomm. on Investigations, S. Comm. On HOMELAND SEC. \& GOV'T AFF., supra note 72, at 3-4, 27 (noting that the work of fusion centers appears to have violated the civil liberties of many U.S. citizens, has not produced successful counterterrorism results, and cost between $\$ 289$ million and $\$ 1.4$ billion in federal funds from 2003-2011); R. Jeffrey Smith, Senate Report Says National Intelligence Fusion Centers have been Useless, CTR. FOR PUB. INTEGRITY (Oct. 3, 2012), http:// www.publicintegrity.org/2012/10/03/11063/senate-report-says-national-intelligence-fusioncenters-have-been-useless, [http://perma.law.harvard.edu/09v7cDvZLdZ] ("warning" sent regarding a Muslim organization's "lecture on positive parenting"). 
surveillance by undercover agents and paid informants. ${ }^{299}$ But for investigative reports or inadvertent leaks, none of this would be privy to the public. Against this highly secretive backdrop of pervasive intelligence gathering, it is reasonable to assume information shared with law enforcement in CCP will be used for intelligence and prosecutorial purposes.

Thus, the extensive network of relationships built through community policing under the guise of building relationships of trust is an alternative means of collecting such information that decreases the risks and costs of hiring ex-felon informants with questionable motives. ${ }^{300}$ Though decreasing the use of shady informants may appear to benefit targeted communities, paid informants will simply be replaced with community members, some of whom may be cognizant of their intelligence-gathering role while many others are unwitting or naïvely oblivious. ${ }^{301}$ So long as racialized counterterrorism practices remain unchanged, replacing paid informants with community leaders only compounds the additional group harm by legitimizing subordinating counterterrorism strategies. ${ }^{302}$

\section{B. Counter-Critiques and the Rhetoric of Empowerment}

Champions of community policing proffer the counter-critique that CCP can be leveraged to change government practices to protect communities' rights and prevent intrusive, "hard" counterterrorism tactics. ${ }^{303}$ They seek to empower communities to counter violent extremism using gentler tactics while leaving counterterrorism to law enforcement, as if the two are separate and distinct. While most supporters are well intentioned, I argue that these proposals not only fail to stop government abuses, they actually worsen subordination of Muslims by creating a false

\footnotetext{
299 See AP's Probe Into NYPD Intelligence Operations, supra note 53; Trevor Aaronson, supra note 277.

300 Natapoff, supra note 13, at 645, 651-54; see Harris, supra note 5, at 177 (admitting that the FBI, NYPD, and other law enforcement groups want Muslim communities' cooperation for the purposes of gathering intelligence); BJELOPERA, supra note 25, at 10-11.

${ }^{301}$ Beutel, supra note 30 , at 20.

302 See, e.g., Henry, supra note 282 (discussing an FBI official's claim that NYPD spying made Muslims "more hesitant to reach out to law enforcement and less trusting").

303 Homeland SEC. Advisory COUNCIL, supra note 4; Murray, supra note 7, at 359; Patel, supra note 107, at 26-27; Robert Wasserman, Guidance for Building Communities of Trust (July 2010), available at http://www.cops.usdoj.gov/files/RIC/Publications/ e071021293_buildingcommtrust_revision.pdf.
} 
sense of progress. Moreover, I challenge the underlying assumption that countering violent extremism and counterterrorism are distinct practices. To the contrary, the former is a preventive component that serves the latter.

As discussed above in Part II, community policing is the new, politically expedient term used to describe counter-radicalization and countering violent extremism, which are as integral to counterterrorism as surveillance, investigations, and criminal prosecutions. And absent the coercive power of the courts or political pressure, law enforcement has little incentive to change its current counterterrorism strategies. Indeed, implementation of current "hard on terror" strategies has led to promotions, public recognition, and more votes for law enforcement officers, notwithstanding the significant adverse consequences to Muslim communities' rights. ${ }^{304}$

Nevertheless, the counter-critiques in support of community policing warrant consideration. ${ }^{305}$ Whether analyzed under the nomenclature of counter-radicalization, community engagement, countering violent extremism, or community policing, proponents make four key arguments in favor of CCP: (1) CCP demystifies and de-vilifies Muslims to officers whose minimal knowledge of Islam is most likely negative; (2) CCP de-securitizes relationships between government and Muslim communities; (3) CCP allows communities to internally police their members from terrorist recruitment using "softer" methods that direct targeted youth to mental health and other social services; ${ }^{306}$ and (4) CCP empowers communities to push for incremental improvements in policies. $^{307}$ Notwithstanding the plausibility of these arguments, they address the symptoms of, rather than offer solutions to, counterterrorism

304 E.g., Press Release, U.S. Dep't of Just., Attorney General Holder Recognizes DOJ Employees and Others for Their Service at Annual Awards Ceremony (Oct. 27, 2010), available at http://www.justice.gov/opa/pr/2010/October/10-ag-1207.html, [http:// perma.law.harvard.edu/0cVAti6Leg8].

305 Harris, supra note 5, at 181 (discussing the perceptions by Muslims that law enforcement does not play fair in pursuit of a conviction).

306 See Terrorism and Our Youth, ISLAMIC LEADERSHIP InST. OF AM. (Feb. 2, 2013), available at http://us 1.campaign-archive $2 . \mathrm{com} / ? \mathrm{u}=5753262 \mathrm{cf} 6639155 \mathrm{beda} 2 \mathrm{cc0} 1 \& \mathrm{id}=$ 4d8cc56c90\&e=ccaf327259, [http://perma.cc/8BTD-XA64].

307 BIPARTISAN POL'Y CTR., supra note 17 , at 7 (discussing community empowerment and engagement without clear definitions of either). 
strategies that disproportionately burden Muslim communities' collective civil liberties. $^{308}$

\section{De-Mystify Muslims and Counter Negative Stereotypes}

Since the September 11th attacks, numerous scholars have examined how Muslims have become racialized as the "Terrorist Other" in the minds of many Americans. ${ }^{309}$ Their otherwise American expressions of dissent or civil grievances are viewed through the lens of disloyalty or ingratitude. ${ }^{310}$ Foreign cultural practices are suspected as subversive and as signals of their unwillingness to assimilate into a Western liberal democracy. ${ }^{311}$ And the bad acts of a few are imputed to the millions of Muslims in America by virtue of their shared faith. ${ }^{312}$ This is so not only because the tenets of Islam are misinterpreted by the public, but also because Muslims' loyalty to their religion is presumed to be irreconcilable with any loyalty to the United States. ${ }^{313}$ If forced to choose, it is supposed, Muslims will choose their religion. ${ }^{314}$

The reification of these stereotypes in counterterrorism occurs through selective enforcement against Muslim individuals and communities. Prosecutions produce a list of Muslim defendants announced in media sources, which serves to reinforce the stereotypes and calls for

\footnotetext{
308 See Ashar, supra note 15, at 1193.

${ }^{309}$ E.g., Ibrahim, supra note 173, at 124-29; Volpp, supra note 6, passim.

${ }^{310} \mathrm{Ibrahim}$, supra note 173 , at 142.

${ }^{311} \mathrm{Id}$. at $142-43$

312 Id.; Salina Kahn, LETTER: Media Stereotypes All Muslims as Violent, MURFREESBORO PosT, May 9, 2013, http://www.murfreesboropost.com/letter-media-stereotypes-allmuslims-as-violent-cms-35463, [http://perma.law.harvard.edu/0KVvSgncZT]; The American Double Standard on Religious Violence, PUb. RELIGION RES. InST. (May 2, 2013), available at http://publicreligion.org/research/graphic-of-the-week/the-americandouble-standard-on-religious-violence/\#.UYbs_Qg_vT5.twitter, [http:// perma.law.harvard.edu/07YR2um7SWv] (finding that $44 \%$ of polled Americans believe that "When people claim to be Muslim and commit acts of violence in the name of Islam that they really are Muslim" compared to $13 \%$ of polled Americans who believed that "people who claim to be Christian and commit acts of violence in the name of Christianity . . . really are Christian"); see also After Boston, Little Change in Views of Islam and Violence, PEW RES. CTR. (May 7, 2013), http://www.people-press.org/ 2013/05/07/after-boston-little-change-in-views-of-islam-and-violence/1/, [http:// perma.law.harvard.edu/0oj4DHHRaGM/] ( $42 \%$ of poll participants indicated a belief that Islam is more likely to promote violent acts than other religions).

${ }^{313}$ Ibrahim, supra note 173 , at 143.

${ }^{314} \mathrm{Id}$.
} 
heightened scrutiny of Muslim communities. ${ }^{315}$ And the cycle continues and expands as more resources are injected into the counterterrorism regime. ${ }^{316}$ For some Muslims, escape from this quagmire lies in engaging with law enforcement to educate them that Muslims are in fact not as prone to terrorism or disloyalty as they are made out to be. By initiating interactions at the individual level with U.S. Attorneys, FBI agents, DHS officials, immigration prosecutors, and others with law enforcement authority, proponents of community policing hope to de-mystify Muslims and directly dispel negative stereotypes. ${ }^{317}$ They leverage these relationships to offer alternative, more accurate sources of information to influence law enforcement training, ${ }^{318}$ intelligence gathering, and the exercise of prosecutorial discretion. By going to the belly of the beast and offering partnership and assistance, proponents believe they can change the very nature of the beast.

According to proponents of CCP, if only law enforcement "gets to know" Muslim communities through community policing programs, then government officials will realize that their current counterterrorism tactics are misguided..$^{319}$ By building personal relationships with federal prosecutors, FBI agents, DHS officials, and local police, Muslim communities will eventually persuade law enforcement to stop sending informants into their communities, spying on Muslims, issuing secret National Security Letters, and engaging in other civil liberties violations. CCP supporters believe engagement with law enforcement will free

\footnotetext{
315 See id. at 144 (discussing performative cues of "Terrorist Other" including surnames); see generally Wadie Said, The Terrorist Informant, 85 WASH. L. REV. 687 (2010).

316 See Ten Years After 9/11 Hearings, supra note 19 (noting that in the first year after 9/11, the FBI added almost 2,000 agents to its national security programs).

317 See Harris, supra note 5, at 183-84.

318 Id. (recommending that Muslims educate law enforcement about social and religious customs and habits of language to avoid innocent behavior being mistaken as indicia of crime).

319 See, e.g., Hussain, supra note 15, at 940-41 (noting some Muslims' belief that civic engagement can improve Americans' views of the Muslim community); Harris, supra note 5, at 162. The key issue is not to make law enforcement more friendly or polite as it enforces a subordinating counterterrorism strategy, but rather to change the strategy to stop subordinating communities. See Murray, supra note 7, at 357 (noting that community policing helps "deflect rumors and reduce misinformation" between police and the communities).
} 
Muslims of their suspect community status. ${ }^{320}$ But CCP's proponents' optimism assumes that the government comes to the table in good faith, willing to make systemic changes to its counterterrorism practices that may subject it to political censure as "soft on terror."

While these engagement efforts mitigate some harm, they ultimately fail to change the counterterrorism strategy and tactics that cause the stigmatizing group harm. On the one hand, when Muslim communities discovered law enforcement was receiving training from anti-Muslim individuals without any expertise on Islam, they were relatively successful in obtaining the U.S. Justice Department's commitment to restructure law enforcement to hire objectively qualified experts that provided accurate information, rather than stereotype-perpetuating propaganda. ${ }^{321}$ But hiring competent trainers for law enforcement should not be mistaken as meaningful counterterrorism reform of selective enforcement of surveillance, investigation, and prosecution based on the religion and politics of the target. And yet, leaders of this campaign touted their preexisting good relations with law enforcement as dispositive of their success, thereby calling for increased engagement between Muslim communities and law enforcement. ${ }^{322}$ On the other hand, the case of the NYPD simultaneously engaging and spying tellingly exposes the minimal incentive law enforcement has to deliver on promises to change counterterrorism practices. Fully cognizant that Muslim communities are subject to negative

320 See, e.g., Ramirez, Hoopes, \& Quinlan, supra note 121. But see Kundnani, supra note 79 , at 8 (finding that "the Prevent programme, in effect, constructs the Muslim population as a 'suspect community', fosters social divisions among Muslims themselves and between Muslims and others, [and] encourages tokenism").

321 E.g., Niraj Warikoo, FBI Ditches Training Materials Criticized as Anti-Muslim, USA TODAY, Feb. 20, 2012, http://usatoday30.usatoday.com/news/nation/story/2012-02-20/fbianti-muslim-training/53168966/1, [http://perma.law.harvard.edu/0mgWEGz4qVY].

322 See, e.g., Spencer Ackerman, FBI Purges Hundreds of Terrorism Documents in Islamophobia Probe, WIRED, Feb. 15, 2012, http://www.wired.com/dangerroom/2012/02/ hundreds-fbi-documents-muslims/, [http://perma.law.harvard.edu/0PkaQeeq24Z] (quoting Rev. C. Welton Gaddy of Interfaith Alliance: "[FBI] Director Mueller acknowledged the seriousness of our concerns and expressed a commitment to maintaining contact with the inter-religious community"). But see Adam Serwer, Muslim Groups: FBI Response to Islamophobia Scandal Not Good Enough, MoTHER JONES, Sept. 28, 2011, http:// www.motherjones.com/politics/2011/09/fbi-response-islamophobia-scandal, [http:// perma.law.harvard.edu/0RYWNnoYqwW] (quoting Abed Ayoub, the legal director of the American-Arab Anti-Discrimination Committee: "Why did [the FBI] not ask for the community's advice on the [training material]? Why didn't they use the resources at their disposal? ... There was no outreach done. That's disappointing"). 
public stereotypes and possess little electoral power, law enforcement can do as it chooses in counterterrorism with little regard for Muslim communities' grievances. ${ }^{323}$ Most likely, community policing will not change this reality. It may instead make it easier to co-opt Muslim communities into the existing counterterrorism strategy and further legitimize it. ${ }^{324}$

2. De-Securitize Relationships Between Law Enforcement and Muslim Communities

Critics of government engagement programs with Muslim communities rightfully point to an over-securitization of these communities. Securitization occurs when the motive for engagement or providing services is tied to preventing terrorism, even if in addition to serving other purposes. ${ }^{325}$ Somali communities in Minneapolis, St. Paul, and other cities, for example, have been under intense government scrutiny for alleged ties to Al-Shabab. ${ }^{326}$ This designated terrorist group in Somalia recruited approximately twenty American young men to fight in the Somali civil war. $^{327}$ This led to a spike in indictments for material support of terrorism charges against individuals who provided humanitarian aid to Somalia, ${ }^{328}$ as

323 See, e.g., Editorial, Spying on Law-Abiding Muslims, N.Y. TIMES, Feb. 9, 2013, http:// www.nytimes.com/2013/02/10/opinion/sunday/spying-on-law-abiding-muslimcitizens.html?_r=0, [http://perma.cc/5BZD-VKDN] (reporting that the NYPD considered being a religious Muslim an indicator of terrorism).

324 See BJElOPERA, supra note 25, at 9; Setty, supra note 5, at 213-14 (arguing that quelling discontent among Muslim communities would encourage buy-in of U.S. counterterrorism policies from Muslim communities and encourage Muslim communities to participate in government counter-radicalization efforts).

325 Beutel, supra note 30, at 17; Rascoff, supra note 73, at 172.

326 See CTR. ON LAW \& SEC., supra note 13, at 24 (showing high numbers of cases alleging material support to Al-Shabab and focus on Minneapolis and California followed by other states where there are Somali communities); Rupa Shenoy, Some Minnesota Somalis Fear Indictments Could Hamper Legitimate Donations, Minn. PuB. Radio News, Aug. 9, 2010, http://minnesota.publicradio.org/display/web/2010/08/09/local-somalis-fear-donationshampered, [http://perma.law.harvard.edu/0flprHib6ba].

327 Eric Schmitt, Islamic Extremist Group Recruits Americans for Civil War, Not Jihad, N.Y. TIMES, June 6, 2010, http://www.nytimes.com/2010/06/07/nyregion/07shabaab.html? $\mathrm{src}=\mathrm{mv} \& \_\mathrm{r}=0,[\mathrm{http}: / /$ perma.cc/A4KZ-EAMM].

328 See Somali Women Humanitarian Workers Convicted on 'Terrorism' Charges, FIGHT BACK NEws, Oct. 20, 2011, http://www.fightbacknews.org/2011/10/20/somali-womenhumanitarian-workers-convicted-terrorism-charges, [http://perma.law.harvard.edu/ 0mmYD6M8aFb] ("[T]wo Somali American women who raised money for charities assisting Somalia's poor, were found guilty of providing material support to foreign 
well as those allegedly seeking to participate in the fighting in Somalia among the various warlords. ${ }^{329}$ Indeed, a Somali-American woman who raised funds in the amount of $\$ 1,450$ allegedly for humanitarian aid purposes in Somalia found herself ensnared in the government's aggressive material support prosecutions. ${ }^{330}$ This scorched-earth strategy may have had a severe chilling effect that deters many Somalis in the United States from having connections with Somalia notwithstanding the dire economic circumstances of their extended families caught in a devastating civil war. ${ }^{331}$ When confronted with criticism of expanding the scope of counterterrorism to conflicts that do not involve the United States, such as a civil war in Somalia, the government responds that it must preventively prosecute these Somali-American young men because they may eventually be co-opted by Al Qaeda operatives to engage in homegrown terrorism. ${ }^{332}$

Thus, when the Department of Homeland Security's Office for Civil Rights and Civil Liberties and the FBI's Specialized Community Outreach Team sought to include the Department of Health and Human Services in their engagement outreach program in Minneapolis and Seattle, where large Somali populations reside, they did so for purposes of decreasing the number of potential terrorist recruits - not solely to provide social services. ${ }^{33}$ CRCL's engagement strategy implicitly assumes Somalis in Minneapolis are more prone to join terrorist groups based on the cases in 2008 and 2009 of young men traveling to Somalia allegedly to join AlShabab. ${ }^{334}$

terrorist organizations."); CTR. ON LAW \& SEC., supra note 13, at 19 (noting that since 2007 , material support has gone from being charged in $11.6 \%$ of cases to $69.4 \%$ in 2010 ).

${ }^{329}$ Schmitt, supra note 327.

330 Elliot Spagat, Somali Woman Gets Prison for Terror Support, AssocIATED PRESS, Dec. 11, 2012, http://bigstory.ap.org/article/somali-woman-gets-prison-terror-support, [http:// perma.cc/L93T-26ZF].

331 Monica Davey, Somali Community in U.S. Fears New Wave of Stigma After Kenya Attack, N.Y. TIMES, Sept. 28, 2013, http://www.nytimes.com/2013/09/29/us/somalicommunity-in-us-fears-new-wave-of-stigma-after-kenya-attack.html, [http://perma.cc/ AGY4-YEPZ]; contra Shenoy, supra note 326.

332 CTR. ON LAW \& SEC., supra note 13, at 4-5; Nine Years After 9/11 Hearings, supra note 110 .

333 Nine Years After 9/11 Hearings, supra note 110.

334 Peter Bergen \& Bruce Hoffman, Assessing the TerRorist Threat: A RePORT OF THE Bipartisan Policy Center's National Security PreParedness Group 10 (Sept. 10, 2010), available at http://bipartisanpolicy.org/sites/default/files/NSPG\%20Final\%20Threat 
Muslim leaders calling for a shift to community policing believe they can continue engagement while de-securitizing the relationship between Muslim communities and law enforcement. ${ }^{335}$ As a result, the basis for interaction will not always be related to preventing terrorism or prosecuting terrorist suspects. Instead, Muslim communities will be treated like any other community in need of certain government services that may or may not impact counterterrorism. These Muslim leaders believe that by shifting the government-community interactions under the rubric of community policing, the common interests will lie in general public safety, employment training, preventing youth delinquency, supporting new immigrants, quality health care, quality education, providing refugees with needed assistance, and other social services. Proponents accept countering terrorism as one of the purposes of community policing, to the extent gang prevention would be such a purpose for African-American or Latino communities participating in community policing, but they do not believe counterterrorism to be the primary or sole purpose. ${ }^{336}$

The problem with this reasoning is twofold. First, community policing in counterterrorism is driven by federal agencies that use local agencies' advantage of having boots on the ground in their respective jurisdictions. ${ }^{337}$ Muslims' political power is weakest at the federal level, as they constitute less than seven percent of the national electorate. ${ }^{338}$ In

\%20Assessment.pdf; CRCL Engages with Somali-American Communities in the Twin Cities, U.S. DEP'T OF HOMELAND SEC. (Jan. 2012), http://www.dhs.gov/crcl-engagessomali-american-communities-twin-cities, [http://perma.cc/0HyDZv8iiqP].

335 Michael Hirsch, Stopping Terrorism at the Source, NAT'L J., May 2, 2013, http:// www.nationaljournal.com/magazine/stopping-terrorism-at-the-source-20130502? print=true, [http://perma.cc/0ZNVRzo9yrA].

336 Beutel, supra note 30 , at 17 (recommending that the government should "leave the counter-radicalization to Muslim communities").

337 See National Research Council, Fairness and Effectiveness in Policing: The EVIDENCE 49 (Wesley Skogan \& Kathleen Frydl eds., 2004) (estimating there are approximately 13,500 local police departments across the country); Matthew. C. Waxman, Police and National Security: American Local Law Enforcement and Counterterrorism After 9/11, 3 J. NAT'L SEC. L. \& POL'Y 377, 386 (2009) available at http://jnslp.com/wpcontent/uploads/2010/08/09_Waxman-Master-12-7-09-.pdf, [http://perma.cc/ 05BcoCRKAmH] (noting there are approximately 730,000 full-time police officers compared to 13,000 FBI special agents).

338 Pew Forum on Religion and Public Life, How the Faithful Voted: 2012 Preliminary Analysis, PEw Res. CTR., Nov. 7, 2012, http://www.pewforum.org/Politics-and-Elections/ How-the-Faithful-Voted-2012-Preliminary-Exit-Poll-Analysis.aspx, [http://perma.cc/ 0GQxDvfExo7] (reporting Muslims and members of other non-Christian faiths accounted for seven percent of the electorate in the 2012 national election). 
contrast, traditional community policing is driven and implemented by local law enforcement that has political incentives to empower communities in ways not directly related to crime ${ }^{339}$ For instance, in the $1990 \mathrm{~s}$, in cities like Chicago, Houston, and New York, local politicians were beholden to African-American voters who demanded civil rights protections from historically abusive police ${ }^{340}$ Those who ignored calls for community policing that reformed abusive police practices and increased public safety in predominantly minority communities risked their political careers. ${ }^{341}$ As such, police chiefs reporting to mayors had powerful incentives to implement community policing in ways that better served communities as opposed to merely co-opting them into a pre-existing subordinating model ${ }^{342}$ That is not to say that these same minority communities were not harmed by broader criminal justice policies and practices that collectively subordinated their communities, such as crack-cocaine sentencing disparities, racial disparities in the death penalty, and racial profiling, to name just a few. ${ }^{343}$ But at the local level, communities had sufficient voting power, access to the media, and access to local politicians to ensure community policing served many of their needs. ${ }^{344}$

The same does not apply to Muslims in the counterterrorism context. The Muslim population of disproportionately first- or secondgeneration immigrants comprises only 2.6 million of the over 350 million people in America, and therefore, has little political power to influence federal policies and practices-the locus of counterterrorism strategy

\footnotetext{
339 Associated Press, Community Policing, CAPS Changes on the Way for Chicago, ABC LoC.-CHI., Jan. 8, 2013, http://abclocal.go.com/wls/story?section=news/ local\&id=8946091, [http://perma.cc/0pnpnLj2ojv]; Building Community Trust, NoRMAN TRANSCRIPT (Jan. 11, 2013), http://normantranscript.com/opinion/x1746077382/Buildingcommunity-trust, [http://perma.cc/0JsVC38wb5k].

340 Tracey L. Meares \& Dan M. Kahan, When Rights Are Wrong: The Paradox of Unwanted Rights, in URGENT TIMES: POLICING AND RIGHTS IN INNER-CiTy COMMUNITIES 3, 12, 27 (Joshua Cohen \& Joel Rogers, eds., 1999).

341 Mears \& Kahan, supra note 340 , at 12, 27; NATIONAL RESEARCH COUNCIL, supra note 337 , at 59 .

342 Associated Press, supra note 341; Building Community Trust, supra note 339.

343 Ramirez, Hoopes, \& Quinlan, supra note 121, at 1197.

344 Muslim Americans: Middle Class and Mostly Mainstream, PEW REs. CTR., May 22, 2007, available at http://www.pewresearch.org/2007/05/22/muslim-americans-middleclass-and-mostly-mainstream/, [http://perma.cc/0WAYVt837yW].
} 
development. ${ }^{345}$ That is not to say they are completely powerless or unable to advocate for their rights, as shown in the case of law enforcement trainings and prosecution of hate crimes. ${ }^{346}$ However, the little they have been able to accomplish is narrowly limited to symptomatic individual cases defending the most egregious civil rights violations without affecting counterterrorism strategy and tactics that collectively subordinate them.

Second, community policing does not challenge the counterterrorism paradigm; it accommodates it. The exclusive focus on Muslim communities, as opposed to community policing in a particular geography where certain social services are most needed, reinforces that Muslims are a suspect community. ${ }^{347}$ Nor does community policing affect the federal laws that grant the government nearly unfettered discretion to spy on Muslim communities. ${ }^{348}$ And history has proven that law enforcement will use its authority to the fullest in furtherance of an

345 Cathy Lynn Grossman, Number of U.S. Muslims to Double, USA TODAY, Jan. 27, 2011, http://usatoday30.usatoday.com/news/religion/2011-01-27-1Amuslim27_ST_N.htm, [http://perma.cc/0hWmG3A8DqD].

${ }^{346}$ Making History, First Sikh Testifies at U.S. Senate Hearing, SIKH CoALITION (Sept. 20, 2012), http:/www.sikhcoalition.org/advisories/2012/making-history-first-sikh-testifies-atus-senate-hearing, [http://perma.cc/ZL8-PBPW]; Letter from Members of Congress to Advisory Policy Board Members (Mar. 21, 2013), available at http://crowley.house.gov/ sites/crowley.house.gov/files/Letter\%20to\%20APB $\% 20$ on $\% 20$ Hate\%20Crimes $\% 20$ Against $\% 20$ Sikhs $\% 20 \mathrm{Hindus} \% 20$ and \%20 Arabs\%2003-2 1-2013.pdf? utm_source $=$ SAALT + Statement + on $+F B I+$ Tracking\&utm_campaign=SAALT + Statement +on+Senate+Immigration+Reform+Bill\&utm_medium=email, [http://perma.cc/ 0cogLV5oWtr]; Hate Crimes and the Threat of Domestic Extremism: Hearing Before the S. Comm. on the Constitution, Civil Rights, and Human Rights, 112th Cong. (2012) (statement of Deepa Iyer, Exec. Director, S. Asian Ams. Leading Together); Memorandum from the S. Asian Ams. Leading Together to the F.B.I. Criminal Just. Info. Servs. Div. (Dec. 14, 2012), http://saalt.org/wp-content/uploads/2012/09/SAALT-Reccomendationsfor-Enhanced-Reporting-and-Collection-of-Hate-Crimes-to-the-Federal-Bureau-ofInvestigation.pdf?utm_source $=$ SAALT+Statement + on $+F B I+T r a c k i n g \& u t m$ campaign $=$ SAALT+Statement+on+Senate+Immigration+Reform+Bill\&utm_medium=email, [http:// perma.cc/0AjF3SXtJj6].

347 HOMELAND SEC. ADVISORY COUNCIL, supra note 4, at 14 (by recommending the roles and responsibilities associated with threat mitigation, the advisory council assumes Muslim communities are a threat).

348 Ronald Kessler, THE Bureau: THE SECRET History OF THE FBI 97 (2002) (describing the FBI's covert targeting of political groups); OFFICE OF THE INSPECTOR GEN., U.S. DEP'T OF Just., The September 11 Detainees: A Review of the Treatment of Aliens Held on Immigration Charges in Connection with the Investigation of the September 11 Attacks (2003), available at http://www.usdoj.gov/oig/special/0306/full.pdf, [http://perma.cc/ 0zJjSyHFkqH]; OfFICE OF THE INSPECTOR GEN., U.S. DEP'T OF JUST., A Review of the FBI's Investigations of Certain Domestic Advocacy Groups (2010), available at 
adversarial system that rewards high volumes of investigations and prosecutions. Including the provision of social services in the counterradicalization component of counterterrorism, which is de facto what community policing will become, does not take away from its overarching objective. Instead of de-securitizing the relationship, community policing merely hides from plain view the counterterrorism objectives and delegates counter-radicalization to Muslim communities.

\section{Delegate Countering Violent Extremism to Muslim Communities}

Some proponents of CCP acknowledge that the government will continue its hard counterterrorism tactics irrespective of community policing. ${ }^{349}$ To some extent, these proponents believe surveillance, investigation, and prosecution are necessary components of protecting national security. ${ }^{350}$ However, they take issue with the government leading the charge on countering violent extremism programs. ${ }^{351}$ They prefer to delegate such efforts to Muslim communities believing that Muslims can better handle and resolve the personal crises that may lead young men to be attracted to terrorist groups. ${ }^{352}$ Rather than law enforcement, Muslim community leaders should intervene in the lives of Muslims on the so-called path to radicalization that could lead to violence. ${ }^{353}$ These proponents believe intervention by community leaders and family members could

http://www.justice.gov/oig/special/s1009r.pdf, [http://perma.cc/0nLDqbBFZW1]; OFFICE OF THE InsPector Gen., U.S. DEP'T OF Just., A Review of the FBI's Use of National Security Letters: Assessment of Corrective Actions and Examination of NSL Usage in 2006 (2008), available at http://Www.justice.gov/oig/special/s0803b/final.pdf, [http://perma.cc/ 0stuYNjNqQt].

${ }^{349}$ Beutel, supra note 30 , at 17 .

$350 \mathrm{Id}$.

351 Michael Hirsh, Stopping Terrorism at the Source, National JoURNAL, May 2, 2013, http://www.nationaljournal.com/magazine/stopping-terrorism-at-the-source-20130502, [http://perma.cc/U967-ECKH] (quoting a Los Angeles-based specialist in gang violence: "This doesn't just come out of nowhere. . . . We are so damn reactive. Our communities have to create some degree of protection. We can't just wait for the Green Berets to come in. At the same time, there is an arrogant attitude on the part of law enforcement that 'we have all the answers. We can do it.' There has to be a collective multidisciplinary collaboration by the community").

352 Beutel, supra note 30 at 17 (recommending that Muslims should take the lead on counter-radicalization because they are most qualified to do so). But see Meares \& Kahan, supra note 340, at 20-21 (describing African-American communities' support for mass home searches in inner city neighborhoods infested with gun and gang violence).

353 BIPARTISAN POL'Y CTR., supra note 17, at 13 (calling for Muslim community intervention as a more effective counter-radicalization tactic). 
prevent terrorist recruitment of young men who suffer from mental health illnesses, personal crises, or other sources of emotional vulnerability. ${ }^{354}$ Thus, rather than ending up in jail or dying in a terrorist attack, these young men could be rehabilitated in the early stages of their radicalization.

While seemingly reasonable, this strategy makes some presumptions that, if false, could prove devastating to Muslim communities' collective liberty interests. First, Muslim communities are presumed to have the capacity and information to know when young men are in the process of becoming terrorists. Domestic terrorism cases involving Muslims show that very few of the defendants were integrated within an American mosque. ${ }^{355}$ To the contrary, most acted alone, with a government informant or undercover agent, or with an international source. ${ }^{356}$ Similarly, to the extent that reports suggest increased terrorism recruitment via the internet, ${ }^{357}$ Muslims are not privy, nor should they be, to the details of each other's internet activities. Indeed, many cases of domestic terrorism both in the United States and Britain have revealed that parents had no knowledge of their sons' alleged online criminal activities. ${ }^{358}$

354 See, e.g., id.

355 See, e.g., Joseph Goldstein, Documents Show Extent of F.B.I. 's Role in Terror Case, N.Y. TIMES, Nov. 14, 2012, http://www.nytimes.com/2012/11/14/nyregion/fbi-had-greater-rolein-jose-pimentel-terrorism-case-documents-show.html, [http://perma.cc/0uEkzp4Xt4j]; see also Beutel, supra note 30 , at 8 (citing cases where individuals who went on to commit or support terrorism were not members of mosques or their congregants); Milton J. Valencia, At Mosque, Suspect's Views Led to Ouster, Boston GloBE, Sept. 30, 2011, available at http://www.boston.com/news/local/massachusetts/articles/2011/09/30/ mosque_ousted_ashland_man_charged_in_terror_plot/, [http://perma.cc/0uHMX2pudjQ] ("The Ashland man who allegedly plotted to fly explosive-laden, remote-controlled airplanes into federal buildings in Washington, D.C., was asked to leave a Roxbury mosque last year because of his radical Islamic views and suspected support of Al Qaeda, a mosque official said yesterday.").

356 See, e.g., Mosi Secret, Man Convicted of a Terrorist Plot to Bomb Subways Is Sent to Prison for Life, N.Y. TIMES, Nov. 16, 2012, http://www.nytimes.com/2012/11/17/nyregion/ adis-medunjanin-convicted-of-subw ay-bomb-plot-gets-life-sentence.html? ref=najibullahzazi, [http://perma.cc/0C2tsgz5cfB]; Goldstein, supra note 355; Brian Ballou, Rezwan Ferdaus of Ashland sentenced to 17 years in Terror Plot; Plotted to Blow up Pentagon, Capitol, Boston.COM, Nov. 1, 2012, http://www.boston.com/metrodesk/ $2012 / 11 / 01 /$ rezwan-ferdaus - ashland-sentenced-years-terror-plot/ KKvy6D6n2PfXfbEfA4iMwJ/story.html, [http://perma.cc/0L9gFsbYbMR].

${ }^{357}$ BIPARTISAN POL'Y CTR, supra note 17 , at 15.

358 See, e.g., Brigid Schulte, Parents of Alleged Terrorists Seek Chues to Sons' Disappearance to Pakistan, WASH. PosT, Apr. 14, 2010, http://www.washingtonpost.com/ wp-dyn/content/article/2010/04/13/AR2010041304351.htm1, [http://perma.cc/ onVt4eZxoB1]. 
Thus, absent intra-community spying, Muslim communities in the United States know very little about individual Muslims' terrorist inclinations. If community intervention implies self-spying, then it supports this Article's thesis that community policing is a subordinating program.

Second, calls for community intervention overlook the serious risk of intra-community censorship of controversial speech, expression, and association rights of Muslims. ${ }^{359}$ Youth, leftists, or women complaining of unjust American foreign policies, imperialism, or intra-community inequities may find themselves silenced by gatekeepers warning them of jeopardizing the entire Muslim community because of their troublemaking. Consequently, pre-existing internal hierarchies along gender, racial, and ethnic lines could be exacerbated. Through community policing, interlocutors, most of whom are men, can further entrench their gatekeeper status wherein Muslim communities are essentialized as one entity and stereotyped based on a few individuals' actions. Even if those individuals are community policing partners with strong relationships with the government, large segments of Muslim communities, particularly youth and women, could suffer an intra-community subordinating effect of being voiceless and bereft of individual agency.

Third, CCP incorrectly assumes that domestic terrorists who are Muslim are integrated into Muslim-American communities. ${ }^{360}$ Domestic terrorism cases, as well as the responses of local Muslim communities, prove otherwise. ${ }^{361}$ The majority of these "homegrown terrorism" cases since 9/11 involve "lone wolf" perpetrators who fall into one of three categories. $^{362}$ The first is young, vulnerable men with mental health or

\footnotetext{
359 Kundnani, supra note 79 , at 11 (highlighting the pressures to avoid radical criticism enforced by community interlopers).

360 See, e.g,. Harris, supra note 5, at 134, 137 (premising his argument on "if we believe that potential terrorists lurk in our Muslim communities, we must have good communications with them" and "the danger posed by an exceptionally tiny number of radicalized Muslims can almost certainly come from only one source: Muslim communities themselves"). My thesis challenges this assumption, without which, there is little justification for community policing unless it is revamped to focus on protecting the interests of Muslim communities. See McCants \& Watts, supra note 8 (highlighting the false assumption that American Muslims are actually susceptible to A1 Qaeda's propaganda in large numbers when in fact that has not proven to be the case).

361 McCants \& Watts, supra note 8.

362 Bergen \& Hoffman, supra note 334, at 5; AARONSON, supra note 190.
} 
financial problems upon whom paid informants prey. ${ }^{363}$ Often, these informants also play leading roles in concocting and implementing the fake terrorist plot. ${ }^{364}$ The second is foreign nationals who come to the United States in collaboration with international terrorists and without the assistance of American Muslim communities. ${ }^{365}$ The third is individuals acting alone or with a few other co-conspirators to carry out a terrorist plot whom are ultimately caught based on predicate acts in furtherance of their illicit plot. ${ }^{366}$ In all three types of cases, Muslim communities in the United States are apparently no more aware of these terrorism-related activities than law enforcement. ${ }^{367}$ Indeed, Muslim communities know much less than law enforcement about these cases because, unlike community members, law enforcement has information drawn from extensive surveillance networks and intelligence databases at the local, state, and federal level. ${ }^{368}$ Thus, one is hard-pressed to determine what added value Muslim

${ }^{363}$ Naomi Wolf, The Spectacle of Terror and its Vested Interests, GUARDIAN, May 9, 2012, http://www.guardian.co.uk/commentisfree/cifamerica/2012/may/09/spectacle-terror-vestedinterests, [http://perma.cc/0Nucg6zMV9J] (giving examples of NYPD and FBI coercing and paying mentally ill or slow individuals in supposed homegrown terrorist plots); Associated Press, supra note 190.

${ }^{364}$ Harris, supra note 5, at 130, 181 (acknowledging government's use of overly aggressive and possibly unfair tactics to pursue individuals who seem to pose no real threat); CTR. ON LAW \& SEC., supra note 13, at 26 (reporting that since 9/11, ten defendants have formally presented entrapment defenses and all were unsuccessful); Annie Sweeney, Chicago Terror Case Sparks Debate About Undercover Stings, CHI. TRIB., June 1, 2013, http:// articles.chicagotribune.com/2013-06-01/news/ct-met-terror-entrap-20130601_1_terrorcase-sami-samir-hassoun-fbi-agents, [http://perma.cc/0iTcJ4oM77H] (reporting on one young adult arrested after planting what he believed to be a bomb, all under the guidance and encouragement of an informant).

365 See, e.g., Charlie Savage, Christmas Day Bomb Plot Detailed in Court Filings, N.Y. TIMES, Feb. 10, 2012, available at http://www.nytimes.com/2012/02/11/us/underwearbomb-plot-detailed-in-court-filings.html, [http://perma.cc/0dxzRDntZFV].

${ }^{366}$ Carpenter, Levitt \& Jacobson, supra note 80 at 307 (discussing the type of "homegrown terrorists" that are inspired by but have no direct ties to Al Qaeda and operate alone).

367 See, e.g., Dan Browning \& Allie Shah, Minneapolis Man Found Guilty of Aiding Somali Terrorist Group, STAR TRIB., Oct. 19, 2012, http://www.startribune.com/local/minneapolis/ 174834731.html? refer=y, [http://perma.cc/0AuGcXUafYT]; Carpenter, Levitt \& Jacobson, supra note 80 , at 312 ; Hirsch, supra note 5 (quoting a Washington business man's observation that "[t]hey just talk about spiritual things. Most of the imams in these mosques come from Pakistan, India, Somalia . . . They all need education, these imams. They just do the prayers. They don't know about the social problems in their mosques").

368 See Ashar, supra note 15, at 1195 (noting that right after 9/11 the DOJ co-opted local law enforcement to assist in race-based questioning, arrest, and detention in immigration); Kelly, supra note 288 , at 558 (praising the PATRIOT Act's decreasing barriers between criminal and counterterrorism investigations allowing more information sharing across local, state, and federal law enforcement agencies); Beutel, supra note 30 , at 8 
communities can contribute other than assisting law enforcement in gathering more intelligence on innocent Muslim communities. ${ }^{369}$

Without information about specific terrorist activity, law enforcement stands to benefit little from CCP, unless its objectives are really about mass surveillance of Muslim communities based on a presumption of collective guilt. ${ }^{370}$ One alternative explanation for the rise of such programs may be that CCP, as its supporters claim, is about empowering Muslim communities to defend their civil rights, integrate into American society, and access government social services. But the veracity of that claim can be easily measured through an assessment of services provided and policies reformed to protect civil liberties. Although beyond the scope of this Article, a preliminary review of community assessments of government engagement highlights the failure to produce substantive policy changes, especially at the systemic level. ${ }^{371}$

Finally, Muslim participants believe their intervention will stop the government's adversarial approach because their cooperation will give them political capital to persuade government that such harsh tactics are neither necessary nor effective. The reality remains that prosecutors face significant political pressure to combat terrorism by indicting, prosecuting, and convicting more, rather than fewer, defendants as part of a prosecution-

(highlighting that extremist ideologues like Abu Hamza and shoe bomber Richard Reid were removed or voluntarily left mosques because their fringe views were not accepted among congregants); Glenn Greenwald, Are All Telephone Calls Recorded and Accessible to the US Government?, GUARDIAN, May 4, 2013, http://www.guardian.co.uk/ commentisfree/2013/may/04/telephone-calls-recorded-fbi-boston, [http://perma.cc/ 0JzyJpcT37b].

369 Letter from Jamie E. Brown, Acting Assistant Att'y Gen., to Rep. John Conyers, Jr., Ranking Minority Member of the H. Comm. on the Judiciary 38-40 (May 13, 2003) (admitting that the new surveillance and infiltration of mosques has not produced information relating to potential terrorism or criminal activity).

370 See, e.g., Kundnani, supra note 79; Arun Kundnani, The Wrong Way to Prevent Homegrown Terrorism, CNN.COM, Dec. 16, 2010, http://www.cnn.com/2010/OPINION/ 12/16/kundnani.prevent.muslim/, [www.perma.cc/0HvRhYNSABS] (critiquing Britain's counter-radicalization program, also known as Prevent, as being used to establish one of the most elaborate systems of surveillance ever seen in Britain); Innes, supra note 117, at 231 ("building a network of community intelligence contacts provides a comparatively effective way of maintaining surveillance over groups and communities" that are especially hard to penetrate).

${ }^{371}$ Carpenter, Levitt \& Jacobson, supra note 80, at 305. In a forthcoming paper, I will delve into more detail on how to measure and hold the government accountable for keeping its promises that community policing serves the interests of Muslim communities. 
driven counterterrorism regime, making Muslim participants' expectations unreasonable. $^{372}$ Indeed, when the Seattle Christmas tree bomber's father solicited the assistance of the FBI because of his concerns about his son's mental health problems, the FBI initiated a sting operation through the use of an informant that led to his son's prosecution for terrorism. ${ }^{373}$ Law enforcement did not respond by seeking mental health intervention. In the end, CCP will not change the deeply entrenched adversarial system.

Moreover, unlike local police who are accountable directly to local communities, federal agencies have little incentive to change their tactics to avoid alienating Muslim communities. For them, it is rational to anger politically powerless communities in exchange for retaining popularity among the majority of Americans who believe Muslims are inherently prone to terrorism, disloyal, and warrant suspicion ${ }^{374}$ Community policing merely serves structural incentives to be "hard on terrorism" by providing more opportunities to gather intelligence for the purpose of investigating and prosecuting more Muslims. ${ }^{375}$

Thus, good faith community intervention does not necessarily protect targeted Muslims (usually young males) from prosecution. To the contrary, prosecutors are likely to exploit their relationships with Muslim community leaders to ask them to persuade their communities that the indictment was necessary based on classified information unavailable to them; that they should trust the prosecutor's judgment and promises that the decision was not an abuse of discretion; and that the prosecution is not indicative of a larger assault on Muslim communities.

\footnotetext{
372 Ten Years After 9/11 Hearings, supra note 19.

373 Bryan Denson, Portland Terrorism Trial: FBI Agents Trace Trail that Led them to Mohamed Mohamud, OREGONIAN, Jan. 23, 2013, available at http://www.oregonlive.com/ pacific-northwest-news/index.ssf/2013/01/portland_terrorism_trial_fbi_a.html, [http:// www.perma.cc/0JuGD85U2bo].

${ }^{374}$ Setty, supra note 5, at 187, passim (arguing that interest convergence must exist in terms of political will to enable Congress and the President to support rights-protective limitations on national security policies); RICHARD POSNER, NOT A SUICIDE PACT 31-51 (2007) (using a cost-benefit analysis to argue in favor of violating civil liberties of Muslims to protect the American majority).

375 Press Release, ACLU, FOI Documents Show FBI Illegally Collecting Intelligence Under Guise of "Community Outreach" (Dec. 1, 2011), available at http://www.aclu.org/ national-security/foia-documents-show-fbi-illegally-collecting-intelligence-under-guisecommunity, [http://www.perma.cc/08BSHT3YRnm/].
} 


\section{Incrementally Reform Counterterrorism Policies through Relationship}

Empowering the community to reform counterterrorism policies and practices incrementally is another commonly invoked justification for community policing. ${ }^{376}$ Implicit in this argument is an admission that sweeping, structural changes in counterterrorism strategy are improbable. The politics of terrorism in America, coupled with entrenched bureaucratic interests in the vast counterterrorism budgets, nearly guarantee counterterrorism's prioritization in the national strategy. ${ }^{377}$ Muslim communities, therefore, are left to focus on incremental reforms that, over the long run, may produce the benefits of structural changes. Proponents of this reasoning are pragmatists willing to accept the "less bad" option of community policing, with all of the attendant risks, rather than boycotting any engagement with the government. ${ }^{378}$ To them, the latter nearly guarantees a perpetuation of the harshest tactics, leaving Muslim communities further disempowered. ${ }^{379}$ Thus, responsible community leaders have an obligation to support community policing with the purpose of incrementally reforming either the most egregious practices or those that the government is most willing to reform.

When criticized as naïve or unduly optimistic, these proponents of CCP point to small victories that have cumulatively improved the civil liberties of Muslims in America. For example, after intensive lobbying at federal civil rights engagement meetings, Muslim and Sikh communities were able to amend DHS's screening process as it relates to religiously

\footnotetext{
376 Innes, supra note 117, at 233; Salam Al-Maryati, The Wrong Way to Fight Terrorism, L.A. Times, Oct. 19, 2011, http://articles.latimes.com/2011/oct/19/opinion/la-oealmarayati-fbi-20111019, [http://www.perma.cc/09LfraAaNna] (defending his twenty years of engagement with the U.S. government as a Muslim leader).

377 See, e.g., Ten Years After 9/11 Hearings, supra note 19 (testifying that a threat-based, intelligence led approach has "transformed the Bureau into a national security organization that fuses traditional law enforcement and intelligence missions").

378 See Written Testimony of Asim Rehman, Federal Civil Rights Engagement with Arab and Muslim American Communities Post 9/11, U.S. Comm'n on Civ. Rts. (Nov. 9, 2012), available at http://www.usccr.gov/calendar/trnscrpt/Transcript_Final_8-2-13.pdf, [http:// www.perma.cc/0hErnMvjoe4/]; Working with Communities Hearing, supra note 26 (statement of Mohamed Elibiary, The Freedom and Justice Foundation co-founder).

379 See Working with Communities Hearing, supra note 26 (statement of Mohamed Elibiary, The Freedom and Justice Foundation co-founder).
} 
mandated headwear. ${ }^{380}$ No longer do Muslim women or Sikh men donning headscarves or turbans, respectively, have to remove their headwear in public when selected for secondary screening. ${ }^{381}$ They now have the option of being screened in a private room. ${ }^{382}$ Moreover, removing the headwear is the option of last resort for TSA screeners after they allow the traveler to self-frisk their heads and then have their hands tested for explosive materials. ${ }^{383}$ However, such marginal reforms do not protect travelers from being selected for secondary screening based on their perceived Muslim identity. Admittedly, this became a moot issue upon DHS's adoption of body scanners through which all travelers must pass, leaving all Americans with diminished privacy. ${ }^{384}$

Another oft-celebrated-but minimal-reform is the suspension of NSEERs ("National Security Entry-Exit Registration System"), a program that required all non-citizen males between the ages of fifteen and forty-five from Muslim-majority countries to register with the government and follow burdensome administrative procedures or face deportation. ${ }^{385}$ NSEERs was passed shortly after $9 / 11$, and it sent the most explicit message to the public, and Muslim communities in particular, that the government was closely tracking Muslim men in the United States as part of its aggressive preventive counterterrorism strategy. ${ }^{386}$ After more than ten years of civil rights advocacy directed at DHS, Department of Justice, and the White House, a coalition of Arab, Muslim, and civil rights and liberties

380 TSA Changes Head Covering Screening Procedure in Response to Concerns of Religious Profiling, SALDEF (Oct. 16, 2007), http://www.saldef.org/news/tsa-changeshead-covering-screening-procedure-in-response-to-concerns-of-religious-profiling/, [http:// www.perma.cc/0jiky J5SeQ7/].

${ }^{381} I d$.

382 See, e.g., Religious and Cultural Needs, TSA, http://www.tsa.gov/traveler-information/ religious-and-cultural-needs, [http://perma.cc/7JXH-XHHY].

${ }^{383}$ See id.

${ }^{384}$ But see Mike Ahlers, TSA Removing 'Virtual Strip Search' Body Scanners, CNN, Jan. 19, 2013, http://www.cnn.com/2013/01/18/travel/tsa-body-scanners, [http://www.perma.cc/ 0pcmoBaXda6/] (removing body scanners because manufacturers could not meet a congressional-ordered deadline to install privacy software on the machines).

385 The NSEERS Effect: A Decade of Racial Profiling, Fear, and Secrecy, RTS. WORKING GRP. (2012), available at http://www.rightsworkinggroup.org/sites/default/files/ RWGPenn_NSEERSReport_060412.pdf; NSEERS: The Consequences of America 's Efforts to Secure Its Borders, AM. ARAB ANTI-DISCRIMINATION COMM. (2009), available at http:// www.detentionwatchnetwork.org/node/2694, [http://perma.cc/R9CS-3CAL].

386 The NSEERS Effect: A Decade of Racial Profiling, Fear, and Secrecy, supra note 385, at 4. 
organizations declared victory in the suspension-though not the complete elimination - of the NSEERs program. ${ }^{387}$ Notwithstanding the protracted time frame for eliminating a clearly discriminatory program, the government admitted that its basis for suspending the program was not concern for Muslims' civil liberties but rather its ability to obtain the same information through other means. ${ }^{388}$ What appeared to be a testament to community engagement with the government was really a reflection of advancements in technology employed by DHS in immigration enforcement. ${ }^{389}$ Hence the underlying discriminatory motive of NSEERs may still exist but is executed through less visible means.

Creation of the Traveler Redress Inquiry Program (“TRIP”) within DHS is also considered a triumph of community engagement and advocacy with federal agencies. ${ }^{390}$ TRIP is tasked with receiving and resolving traveler complaints of misidentification or erroneous inclusion on terrorist watch lists and No Fly lists. ${ }^{391}$ The program was created to relieve DHS's Office for Civil Rights and Civil Liberties, which at the time had minimal complaint adjudication capacity, from resolving the thousands of complaints

387 See, e.g., Chris Rickerd, Homeland Security Suspends Ineffective, Discriminatory Immigration Program, ACLU BLOG OF RTS (May 6, 2011), http://www.aclu.org/blog/ immigrants-rights-racial-justice/homeland-security-suspends-ineffective-discriminatory, [http://www.perma.cc/02tS7k9bhDx].

388 U.S. DEP'T OF HOMELAND SEC., Removing Designated Countries From the National Security Entry-Exit Registration System (NSEERS), 76 Fed. Reg. 82, 23830 (Apr. 28, 2011) ("Over the past six years, the Department of Homeland Security (DHS) has implemented several new automated systems that capture arrival and exit information on nonimmigrant travelers to the United States, and DHS has determined that recapturing this data manually when a nonimmigrant is seeking admission to the United States is redundant and no longer provides any increase in security."); see also Rickerd, supra note 387 ("DHS's suspension of the NSEERS program didn't even merit a posting on DHS's website, much less a plan to communicate to those harmed by NSEERS. Tellingly, DHS justified NSSERS' suspension only on efficiency grounds . . . and completely glossed over the program's civil liberties costs.").

389 U.S. DEP'T OF HOMELAND SEC., supra note 388.

${ }^{390}$ E.g., ADC Welcomes New TSA Aviation Security and Traveler Screening Enhancements, ARAB AMERICA, http://www.arabamerica.com/michigan/california/news.php?id=103, [http://www.perma.cc/0QkvyzGa2bL/].

391 See, e.g., Five Years After the Intelligence Reform and Terrorism Prevention Act: Stopping Terrorist Travel: Hearing Before the H. Comm. on Homeland Sec. and Governmental Aff., 111th Cong. (2009), available at http:/www.fbi.gov/news/testimony/ the-terrorist-screening-center-and-its-role-in-combating-terrorist-travel, [http:// www.perma.cc/0gd6USHuhC2/] (statement of Timothy Healy, Director, Terrorist Screening Center, FBI) (stating "only 0.7 percent of the DHS TRIP complaints actually have some 
by aggrieved travelers, most of whom were Muslim. ${ }^{392}$ But soon after its inception, TRIP became notorious for its late responses, which sometimes came years after a complaint was filed, and for the absence of due process for complainants to meaningfully challenge their inclusion on a list. $^{393}$ Moreover, TRIP's opaque and terse responses, known as Glomar responses, ${ }^{394}$ wherein the government refuses either to confirm or deny the existence of a violation, left complainants convinced that the complaint process was a façade that allowed the government to claim it safeguarded civil liberties without permitting meaningful challenge. ${ }^{395}$ The government has all of the information while the traveler is kept in the dark throughout the redress process. ${ }^{396}$ Six years after its inception, TRIP is still encumbered with a high volume of complaints, is short of staff, and has little power to affect the front end of the watch listing process to decrease the number of false positives or misidentification. ${ }^{397}$

Other proclaimed victories involve individual civil rights violations by private actors. While significant to Muslims' collective rights interests,

connection to the Terrorist Watchlist. Of the 0.7 percent that have a connection to the watchlist, approximately 51 percent are appropriately watchlisted, 22 percent have been modified or reviewed prior to redress, 10 percent were similar names, and 15 percent were removed or downgraded due to the redress process"); Amy Pavuk, supra note 185 (describing Muslim man harassed over lengthy period of time when traveling because on watch list).

392 Letter from Marcia Hoffman to Electronic Frontier Foundation, TRIP Complaint Statistics (Jan. 21, 2010), available at https://www.eff.org/sites/default/files/filenode/ trip_complaints/20100121_trip_complaints.pdf (reporting over 66,000 complaints between Feb. 20, 2007 and Aug. 6, 2009); ANNY P. BAKALIAN \& MEHDI BOZORGMEHR, BACKLASH 9/11: MiddLE EASTERN AND MUSLIM AMERICANS RESPOND 183 (2009).

393 See, e.g., Problem-Filled Traveler Redress Program Won't Fly, Elec. Privacy Info. CTR. (Nov. 2006), http://epic.org/privacy/surveillance/spotlight/1106/default.html, [http:// www.perma.cc/0oXWRgsTRRz/]. But see Letter from Marcia Hoffman to Electronic Frontier Foundation, supra note 392 (reporting that from 2007-2009, 54\% of complaints were resolved in less than ninety days, $15 \%$ in ninety-one to 180 days, $15 \%$ in 181 to 360 days, and $15 \%$ in more than one year).

${ }^{394}$ Military Audit Project v. Casey, 656 F.2d 724 (D.C. Cir. 1981); Phillipi v. CIA, 546 F.2d 1009 (D.C. Cir. 1976).

395 Dept. Of Homeland Sec., Effectiveness of the Department of Homeland SECURITY TRAVELER REDRESS INQUIRY PROGRAM 89-90 (Sept. 2009), available at http:// www.oig.dhs.gov/assets/Mgmt/OIG-09-103r_Sep09.pdf; Stellin, supra note 186.

${ }^{396}$ DEPT. OF HOMELAND SEC., supra note $39 \overline{5}$, at 89.

397 Problem-Filled Traveler Redress Program Won't Fly, supra note 393; DEPT. OF HOMELAND SEC., Memorandum on TRIPS (2006), available at http://www.archives.gov/ records-mgmt/rcs/schedules/departments/department-of-homeland-security/rg-0563/ n1-563-09-008_sf115.pdf. 
these cases are handled by federal offices with an exclusively civil rights enforcement agenda such as the Equal Employment Opportunity Commission and the Civil Rights Division at the U.S. Department of Justice. $^{398}$ Institutional and political incentives directly contribute to their proactive enforcement of individual civil rights violations that are symptoms of the preventive counterterrorism strategy. Notably, these offices lack the legal authority to hold accountable other federal offices alleged to have violated Muslims' civil liberties. ${ }^{399}$ These small successes, while important for the individual victim, do not cure the systemic subordination effect, and thus should not be mistaken for systemic policy reforms necessary to protect Muslim communities' interests.

\section{Conclusion}

As this Article demonstrates, community policing in counterterrorism is fraught with adverse consequences that may be overlooked by Muslim proponents and local law enforcement. CCP's implementation occurs within a broader federal counterterrorism strategy that subordinates Muslim communities in various ways. Specifically, current counterterrorism strategy, among other things, selectively targets Muslims notwithstanding the rise of non-Muslim right wing groups that engage in violence; criminalizes humanitarian aid to conflict zones in Muslim-majority countries, ${ }^{400}$ conflates political dissent and orthodox Islamic practices with unlawful terrorism; profiles Muslims in travel screening and terrorist watch listing; and targets impressionable young Muslim men with mental health problems for sting operations where informants play a leading role.

\footnotetext{
398 See, e.g., Press Release, EEOC, Court Finds for EEOC in Religious Discrimination Suit Against Abercrombie and Fitch (July 15, 2011), available at hitp://www.eeoc.gov/eeoc/ newsroom/release/7-15-11a.cfm, [http://www.perma.cc/0KCAFAtJi9c/]; Initiative to Combat Post-9/11 Discriminatory Backlash, Enforcement and Outreach, U.S. DEP'T OF JUST., http://www.justice.gov/crt/legalinfo/discrimupdate.php, [http://perma.cc/8S7XWYAY].

399 Authority \& Role, U.S. EEOC, http://www.eeoc.gov/eeoc/, [http://www.perma.cc/ 0dCwkzzizf5/]; About the Division, U.S. DEP'T OF JUST., http://www.justice.gov/crt/about/, [http://www.perma.cc/09XVomf2pi/].

400 Holder v. Humanitarian Law Project, 561 U.S. 1 (2010); KATE MACKINTOSH \& PATRICK DUPlat, STUDY OF THE IMPACT OF DONOR COUNTER-TERRORISM MEASURES ON PRINCIPLED HUMANITARIAN ACTION 40-47 (2013), available at http://www.nrc.no/arch/ _img/9680215.pdf.
} 
Unlike community policing employed in inner city communities and developed in response to ineffective paramilitary policing models, CCP keeps intact the preventive counterterrorism paradigm that adopts the military counterinsurgency tactics of counter-radicalization and domestic criminal justice priorities of surveillance, investigation, and prosecution. In contrast to traditional community policing where citizens seek the protection of local law enforcement from third-party drug dealers, gangsters, and other criminal elements, Muslim communities engage with federal law enforcement to dissuade them from violating their collective rights. And as they beseech their government to respect their civil liberties, Muslims must also seek the protection of law enforcement against private acts of violence and discrimination. ${ }^{401}$ For many Muslims, the government may come across as more foe than friend. ${ }^{402}$

Thus, CCP as currently envisioned betrays its rhetoric of empowerment and mutual trust and is merely another tool in the federal government's toolkit that perpetuates the "Terrorist Other" stereotype. ${ }^{403}$ Without systemic reforms of the underlying strategy and overreaching tactics, community policing will merely co-opt Muslim communities and local law enforcement into a highly flawed counterterrorism regime to the detriment of their otherwise good relations. ${ }^{404}$

While community policing programs could in theory benefit Muslim communities' collective interests, as described in the countercritiques in Part III.B above, CCP's predecessor programs prove that in practice the results are likely to be otherwise. Community engagement and outreach programs have only left Muslim communities frustrated with the government's inability or refusal to adopt a systemic approach to resolving civil liberties grievances. Grievances are addressed, if at all, on an individual level, making the process analogous to scooping water out of an ocean with a spoon. Even if an individual complaint is resolved, there are

\footnotetext{
${ }^{401}$ Hussain, supra note 15, at 934; Ashar, supra note 15, at 1189.

402 See EMPOWERING LoCAL PARTNERS, supra note 17; STRATEGIC Plan FOR EMPOWERING LOCAL PARTNERS, supra note 4; BIPARTISAN POL'Y CTR., supra note 17, at 10; Chinese \& Weichselbaum, supra note 17.

${ }_{403}$ Margulies \& Metcalf, supra note 6, at 436; see also Alibeli \& Yaghi, supra note 6 (discussing the scapegoating of American Muslims). See Volpp, supra note 6, passim for a discussion of the post-9/11 othering of persons who appear to be of Arab descent as terrorists.

${ }^{404}$ See PRICE, supra note 5, at 39-40.
} 
hundreds more arising from policies and practices that are fundamentally rights-infringing and selectively enforced. Meanwhile, community attendees have discovered that some, and possibly all, FBI outreach meetings are used to gather intelligence on Muslim communities, which is then input into intelligence databases accessible across local, state, and federal agencies.

Rather than focus on how to co-opt Muslim communities into existing paradigms, the efforts of local law enforcement and communities are better spent shifting the paradigm away from the use of religious affiliation and ethnic origin as indicia of terrorism to focusing on individualized suspicion based on predicate acts of criminal activity and an assumption of the innocence of Muslim communities. For that to happen, the federal law enforcement agencies must undergo the same monumental cultural and political changes as local police departments did in the 1990s in order to make traditional community policing a relative success. Until then, community policing should be rejected by both local law enforcement and Muslim communities alike. 